

\section{Mission}

ATINER is a World Non-Profit Association of Academics and Researchers based in Athens. ATINER is an independent Association with a Mission to become a forum where Academics and Researchers from all over the world can meet in Athens, exchange ideas on their research and discuss future developments in their disciplines, as well as engage with professionals from other fields. Athens was chosen because of its long history of academic gatherings, which go back thousands of years to Plato's Academy and Aristotle's Lyceum. Both these historic places are within walking distance from ATINER's downtown offices. Since antiquity, Athens was an open city. In the words of Pericles, Athens"... is open to the world, we never expel a foreigner from learning or seeing". ("Pericles' Funeral Oration", in Thucydides, The History of the Peloponnesian War). It is ATINER's mission to revive the glory of Ancient Athens by inviting the World Academic Community to the city, to learn from each other in an environment of freedom and respect for other people's opinions and beliefs. After all, the free expression of one's opinion formed the basis for the development of democracy, and Athens was its cradle. As it turned out, the Golden Age of Athens was in fact, the Golden Age of the Western Civilization. Education and (Re)searching for the 'truth' are the pillars of any free (democratic) society. This is the reason why Education and Research are the two core words in ATINER's name. 
The Athens Journal of Business \& Economics

ISSN NUMBER: 2241-794X- DOI: 10.30958/ajbe

Volume 5, Issue 2, April 2019

Download the entire issue $(\underline{\mathrm{PDF}})$

Front Pages

i-viii

The Interrelation between Manufacturing Productivity,

Maximum Sectoral Employment and National Income

Per Capita

Rainer Przywara

Bangladesh Trade with India: Trends and Patterns

Bhoodan-Based Corporate Citizenship: Corporate

Accountability Based on Serving and Empowering Land-Owners and Users

Siddharth Mohapatra \& Pratima Verma

Identity and Perception of Risk for Entrepreneurs: 163 Lessons from an Industrially Less Developed State in India

Debdatta Saha 


\section{Athens Journal of Business \& Economics Editorial and Reviewers' Board}

\section{Editors}

- Dr. Christos Sakellariou, Associate Professor of Economics, Nanyang Technological University, Singapore \& Vice President of Administration and Finance, Athens Institute for Education and Research (ATINER).

- Dr. Gregory T. Papanikos, Honorary Professor, University of Stirling, UK \& President of ATINER.

- Dr. Peter Yannopoulos, Professor, Brock University, Canada \& Vice President of Global Communications, ATINER.

- Dr. Julia Underwood, Professor, Azusa Pacific University, USA \& Academic Member, ATINER.

- Dr. Nektarios Tzempelikos, Senior Lecturer in Marketing, Anglia Ruskin University, UK.

\section{Editorial Board}

- Dr. Panagiotis Petratos, Vice President of ICT, ATINER \& Professor, Department of Computer Information Systems, California State University (Stanislaus), USA.

- Dr. Michael P. Malloy, Director, Business \& Law Research Division, ATINER \& Distinguished Professor of Law, University of the Pacific, USA.

- Dr. Peter Koveos, Head, Accounting \& Finance Research Unit, ATINER \& Professor of Finance, Syracuse University, USA.

- Dr. Sharon Claire Bolton, Head, Management Research Unit, ATINER \& Professor, The Management School, University of Stirling, Scotland.

- Dr. Cleopatra Veloutsou, Head, Marketing Research Unit, ATINER \& Professor of Brand Management, University of Glasgow.

- Dr. John Thanopoulos, Professor of International Business (IB), and Dean, Business and Economics, IST

College \& Emeritus Professor, University of Piraeus, Greece.

- Dr. Elyas Elyasiani, Professor Finance and Economics, Fox School of Business and Management, Temple University, USA.

- Dr. Eduardo Segarra, Academic Member, ATINER \& Professor, Department of Agricultural \& Applied Economics, Texas Tech University, USA.

- Dr. Samuel Seaman, Academic Member, ATINER \& Professor of Decision Sciences, Graziadio School of Business and Management, Pepperdine University, USA.

- Dr. Hercules Haralambides, Academic Member, ATINER \& Professor of Maritime Economics and Logistics, Department of Econometrics, Erasmus University Rotterdam, The Netherlands.

- Dr. Steven Dellaportas, Academic Member, ATINER \& Professor of Accounting, RMIT (Royal Melbourne Institute of Technology) University, Australia.

- Dr. George V. Priovolos, Professor, Iona College, USA.

- Dr. George Saridakis, Director of Doctoral Programmes, Kingston Business School, Kingston University \&

Professor of Small Business and Entrepreneurship, Kingston Hill, Kingston Upon Thames, UK.

- Dr. Liliana Costa, Tutor, Department of Communication and Art, University of Aveiro, Portugal.

- Dr. Gilles Chemla, Academic Member, ATINER \& Professor, Imperial College Business School, UK.

- Dr. Nathalie Homlong, Associate Professor, University College Volda, Norway.

- Dr. Tatyana Boikova, Associate Professor, Business Administration Department, Baltic International Academy, Latvia.

- Dr. Zubin Sethna, Associate Professor of Entrepreneurial Marketing, Regent's University London, UK.

- General Managing Editor of all ATINER's Publications: Ms. Afrodete Papanikou

- ICT Managing Editor of all ATINER's Publications: Mr. Kostas Spyropoulos

- Managing Editor of this Journal: Ms Fani Balaska (bio)

\section{Reviewers' Board}




\section{President's Message}

All ATINER"s publications including the e-journals are open access without any costs (submission, processing, publishing, open access paid by authors, open access paid by readers etc) and are independent of the presentations made at any of the many small events (conferences, symposiums, forums, colloquiums, courses, roundtable discussions) organized by ATINER throughout the year. The intellectual property rights of the submitted papers remain with the author.

Before you submit, please make sure your paper meets some basic academic standards, which include proper English. Some articles will be selected from the numerous papers that have been presented at the various annual international academic conferences organized by the different divisions and units of the Athens Institute for Education and Research.

The plethora of papers presented every year will enable the editorial board of each journal to select the best ones, and in so doing, to produce a quality academic journal. In addition to papers presented, ATINER encourages the independent submission of papers to be evaluated for publication.

The current issue of the Athens Journal of Business and Economics (AJBE) is the second issue of the fifth volume (2019). The reader will notice some changes compared with the previous issues, which I hope is an improvement. An effort has been made to include papers which fall within in one of the subfields of business and economics.

This issue includes 4 papers related to different aspects of business and economic studies. The first is an economic paper on manufacturing productivity; the second on trade, the third one on social entrepreneurship and corporate citizenship, while the fourth paper refers to industrial policy and entrepreneurial identity and risk perception. The AJBE is truly an international journal; this is also reflected in this issue both in terms of authors and empirical content of the papers.

Gregory T. Papanikos, President

Athens Institute for Education and Research 


\section{Athens Institute for Education and Research}

A World Association of Academics and Researchers

\section{$14^{\text {th }}$ Annual International Symposium on Economic Theory, Policy and Applications 1-4 July 2019, Athens, Greece}

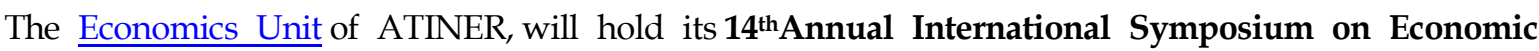
Theory, Policy and Applications 1-4 July 2019, Athens, Greece sponsored by the Athens Journal of Business \& Economics. The aim of the conference is to bring together academics and researchers of all areas of economics and other related disciplines. You may participate as panel organizer, presenter of one paper, chair a session or observer. Please submit a proposal using the form available (https://www.atiner.gr/2019/FORM-ECO.doc).

\section{Academic Members Responsible for the Conference}

- Dr. Gregory T. Papanikos, President, ATINER \& Honorary Professor, University of Stirling, UK.

- Dr. Chris Sakellariou, Head, Economics Unit \& Associate Professor of Economics, Nanyang Technological University, Singapore.

Important Dates

- Abstract Submission: 4 March 2019

- Acceptance of Abstract: 4 Weeks after Submission

- Submission of Paper: 3 June 2019

\section{Social and Educational Program}

The Social Program Emphasizes the Educational Aspect of the Academic Meetings of Atiner.

- Greek Night Entertainment (This is the official dinner of the conference)

- Athens Sightseeing: Old and New-An Educational Urban Walk

- Social Dinner

- Mycenae Visit

- Exploration of the Aegean Islands

- Delphi Visit

- Ancient Corinth and Cape Sounion

\section{Conference Fees}

Conference fees vary from $400 €$ to $2000 €$

Details can be found at: https://www.atiner.gr/2019fees 


\section{Athens Institute for Education and Research}

A World Association of Academics and Researchers

\section{$6^{\text {th }}$ Annual International Conference on Business, Law \& Economics 6-9 May 2019, Athens, Greece}

The Business, Economics and Law Division (BLRD) of ATINER is organizing its $6^{\text {th }}$ Annual International Conference on Business, Law \& Economics, 6-9 May 2019, Athens, Greece in collaboration with the MLC Management \& Law College of Ljubljana, sponsored by the Athens Journal of Business \& Economics and the Athens Journal of Law. In the past, the six units of BLRD have organized more than 40 annual international conferences on accounting, finance, management, marketing, law and economics. This annual international conference offers an opportunity for cross disciplinary presentations on all aspects of business, law and economics. Please submit an abstract (email only) to: atiner@atiner.gr, using the abstract submission form (https:/ / www.atiner.gr/2019/FORM-BLE.doc)

\section{Important Dates}

- Abstract Submission: 25 March 2019

- Acceptance of Abstract: 4 Weeks after Submission

- Submission of Paper: 8 April 2019

\section{Academic Member Responsible for the Conference}

- Dr. Gregory T. Papanikos, President, ATINER.

- Dr. Michael P. Malloy, Director, Business, Economics and Law Division, ATINER \& Distinguished Professor \& Scholar, University of the Pacific, USA.

- Dr. David A. Frenkel, LL.D., Head, Law Research Unit, ATINER \& Emeritus Professor, Law Area, Guilford Glazer Faculty of Business and Management, Ben-Gurion University of the Negev, Beer-Sheva, Israel.

\section{Social and Educational Program}

The Social Program Emphasizes the Educational Aspect of the Academic Meetings of Atiner.

- Greek Night Entertainment (This is the official dinner of the conference)

- Athens Sightseeing: Old and New-An Educational Urban Walk

- Social Dinner

- Mycenae Visit

- Exploration of the Aegean Islands

- Delphi Visit

- Ancient Corinth and Cape Sounion

More information can be found here: https://www.atiner.gr/social-program

\section{Conference Fees}

Conference fees vary from $400 €$ to $2000 €$

Details can be found at: https://www.atiner.gr/2019fees 



\title{
The Interrelation between Manufacturing Productivity, Maximum Sectoral Employment and National Income Per Capita
}

\author{
By Rainer Przywara*
}

\begin{abstract}
According to the three-sector hypothesis, the national share of employees in the industrial sector will be shrinking after having reached a specific peak level. In line with societal development over time, the tipping point at which deindustrialization starts should be related to a certain income per capita. Predictions from literature showed an inverted-U relationship of manufacturing employment (\%) over income per capita (log) for mature countries. By regression analysis, a universal tipping point at which deindustrialization starts was calculated. In this study, this theory was tested on a sample of 12 mature (high income, tipping by 1980) and 25 emerging (upper-middle income, later tipping) countries. No single standard function for all national economies was found, but certain paths related to the general state of economic development of national economies. The tipping point is moving over time, driven by increasing sectoral productivity. Productivity rises result in a shift over time towards higher income ( $x$-axis) and lower relative employment (y-axis). In accordance with existing theory, the country-specific maximum of relative employment in manufacturing is reached at a certain threshold productivity, which again corresponds to a specific national income per capita. As a stylized fact, two falling linear functions of maximum manufacturing employment (\%) over GDP per capita (log) were identified for mature and emerging countries. Their divide follows the international division of labour between highly-productive technology owners (mature countries) and less productive sub-suppliers (emerging countries). In addition, the critical manufacturing productivity at which maximum manufacturing employment is reached was analysed as a function of time (tipping year). Corresponding to the findings on the tipping point, the critical manufacturing productivity is rising over time. Two markedly separated rising linear functions for mature and emerging countries were identified.
\end{abstract}

Keywords: Structural Change, Economic Sectors, Sectoral Employment, Manufacturing, Productivity, Tipping Point, Economic Policies

\section{Introduction}

The three-sector hypothesis predicts a standard pattern of different forms of societal development, each characterized by the leading macro-economic sector of the national economy. The agricultural society will be replaced by the industrial society which will then be followed by the service society. In this course, first agriculture, then industry will reach a peak level of relative employment over time. Since manufacturing is a very relevant industrial sector for assuring national welfare in terms of product supply and the trade balance, in most discussions on sectoral change it stands for industry as a whole.

"Professor, President, Baden-Wuerttemberg Cooperative State University Heidenheim, Germany. 
After reaching the tipping point of relative employment, the national share of employees in manufacturing will be shrinking. Often, this process is denominated as 'deindustrialization'. This is notwithstanding the fact that in the case of rising productivity, reduced employment does not necessarily go along with reduced output. In fact, the incidences of reduced output are rare; the UK has been the most prominent case over the last decade (Przywara 2016).

As a long-term trend, the income per capita of a socio-economically stable country will rise continuously on the basis of rising productivity. In line with this development, the tipping point of manufacturing employment will be related to income per capita. Rowthorn (1994) predicted an inverted-U relationship of manufacturing employment (\%) over income per capita (log). By regression analysis, he calculated the tipping point at which deindustrialization starts.

In this paper, Rowthorn's theory was tested on a sample of 12 mature countries (maximum employment in manufacturing by 1980) and 25 emerging countries (countries before the tipping point by 1980).

\section{Literature Review}

This literature review consists of the following elements:

introduction to the three-sector hypothesis of sectoral change of a national economy,

explanation of the role of manufacturing within a national economy

delineation of definitions of deindustrialization,

description of the tipping point prediction of relative manufacturing employment over GDP per capita by Rowthorn (1994).

The results were taken as the starting point of the actual analysis, aiming at a comprehensive theory of sectoral change with specific regard to manufacturing employment and national wealth.

\section{The Three-Sector Hypothesis}

The three-sector hypothesis is a politico-economic theory describing and predicting sectoral structural change of a national economy (Klodt 2014c). On a low level of development, the primary sector (agriculture) dominates, later the secondary sector (industrial production) and, as the final achievement, the tertiary sector (services) (Klodt 2014b).

The three-sector theory was introduced by the British economists Fisher (1935) and Clark (1940) and taken further by the French economist Fourastié (1949). Clark (1940) was inspired by a remark of Petty (1690) published posthumously. Petty's idea of labour reallocation from agriculture to nonagricultural activities, the very ground for the three-sector hypothesis, is often referred to as Petty's Law, e.g. by Murata (2008). In Petty's own words, it reads: 
"There is more to be gained by manufacture than by husbandry, and by merchandise than by manufacture" (cited after Hospers and Steenge 2002: 9).

After being translated into German in 1954, Fourastié's book was very influential in the German-speaking countries (Pohl 1970). Unlike his two immediate British predecessors, Fourastié did not only provide descriptions of the phenomena, but tried to identify the mechanisms behind them, namely technology and population growth (Hospers and Steenge 2002). On this basis, he predicted a transition of all then-developed societies to service societies by millennium. The phenomenon of a relative decline in industrial employment after reaching an alltime peak is considered as 'deindustrialization' (Klodt 2014b).

Figure 1. Standard Pattern of Structural Change

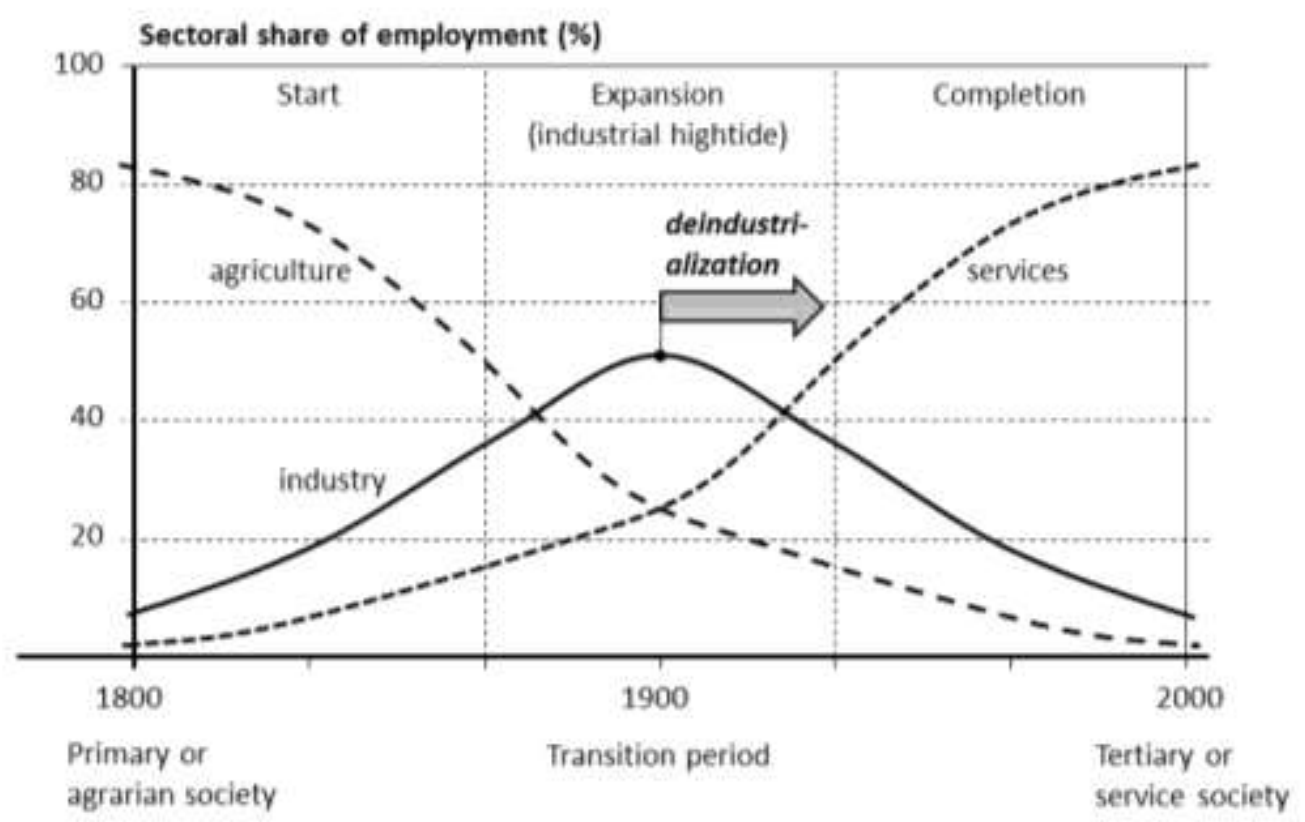

Source: Author's graph, after Henning (1995: 21), stylized scheme.

According to the three-sector hypothesis, the sectoral shift is mainly driven by two mechanisms:

1. Rising income elasticity of demand:

On a low income level, the demand for goods is relatively inelastic and focused on the coverage of basic needs. With rising income, the elasticity of demand rises. Thus, industrial goods and - in the course of development - services become more and more favoured.

2. Different productivity growth rates per sector

Technical progress leads to different patterns of growth per sector. In the secondary sector (capital-intensive production), the labour content is constantly reduced by innovations (automation), so a relative decline in sectoral employment results.

Possibilities for productivity rises in the tertiary sector were considered as limited by the authors of the middle 20th century (Klodt 2014b). 
The outlined pattern of structural change has been demonstrated in general by empirical studies (Pohl 1970). This notwithstanding, the presumption of a general backlog in productivity of the tertiary sector did not prove to be appropriate. It was based on the somewhat antiquated notion of services as typically being consumer-oriented. In recent decades, production- or enterpriseoriented services (e.g. financial or technical services) have played an important and still growing role. Modern information and communication technologies (ICT services) have contributed to increase the productivity of most other fields of goods and services (Klodt 2014a). Therefore, the dominant factor for the advancement of services can be seen in a shift of demand (Klodt 2014b).

\section{The Role of Manufacturing}

The classical three-sector hypothesis subsumes all industrial activities under the caption 'secondary sector'. According to the ISIC 4 classification, these are:

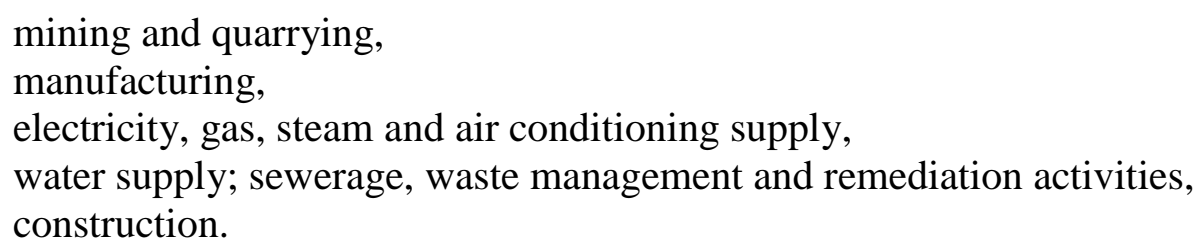

Since manufacturing assures the supply of goods and involves the majority of persons employed in the industrial sector, later analyses of sectoral change often focused on manufacturing. Moreover, the idea that "there is something special about manufacturing", as Kitson and Michie (2014: 322) put it, evolved. Among the authors that argued in that direction were Young (1928), Lewis (1954) and Kaldor (1966). Kaldor was of major influence not only in the scientific debate, but in real life as an advisor for the British Labour government since 1964 (Dasgupta and Singh 2006).

Kaldor derived his idea of the central role of manufacturing for the prosperity of an economy from diagnosed differences in central economic features of the economic sectors. He assumed an income elasticity of demand similar to that of services, but higher than that of agriculture (Dasgupta and Singh 2006). On the supply side, he estimated the productivity growth of manufacturing higher than that of both other sectors because of its exclusive potential to utilize economies of scale (Kitson and Michie 2014). From these basic assumptions, he derived generalizations known as 'Kaldor's laws'.

As Singh (1977) noted, the manufacturing sector is of crucial influence on the external balance of a country. He followed that idea three decades later when noticing that UK manufacturing accounted for less than $20 \%$ of the GDP, but still for $60 \%$ of its foreign trade (Dasgupta and Singh 2006). In line with this idea, in the course of its decline in manufacturing, from the early 1980s the UK for the first time since the industrial revolution had a negative balance on manufactures (Kitson and Michie 2014). 
More recent discussions focussed on the idea that knowledge-intensive services could serve as a compensation for lacking manufacturing in a national economy. This argument is around the idea that the British Chancellor of the Exchequer, Nigel Lawson, delineated as follows (Lawson 1985: 554): "[T]here is no adamantine law that says we have to produce as much in the way of manufacturing as we consume. If it does turn out that we are more efficient in world terms at providing services than at producing goods, then our national interest lies in a surplus on services and a deficit on goods."

In a Kaldorian analysis, many services clearly depend on manufacturing, so Nigel Lawson's idea would not work out. But Kaldor's analysis, quite adequate at his day, referred to rather simple services (e.g. personal services and transportation). If high-technology services are concerned that have only recently been made available, knowledge-intensive business services (KIBS) like ICT services may well generate follow-up growth even in manufacturing (Dasgupta and Singh 2006).

The question remains whether services can fully replace the manufacturing sector. Kitson and Michie (2014) cast serious doubt on that assumption by highlighting the aforementioned trade deficit and regional imbalances resulting from a weak manufacturing sector in the UK. They blame ill-led capital flows, e.g. into a too big financial sector, for the distortions.

\section{Definitions of Deindustrialization}

In Kaldor's academic footsteps, Kollmeyer (2009) defined deindustrialization as a relative decline in manufacturing employment. He claimed this to be the single adequate definition of deindustrialization, but although Kollmeyer's definition is quite common in sociology and serves well to describe certain socioeconomic phenomena, it can neither be considered as complete nor universally adequate:

It does not comprise a time frame for structural change.

It only refers to the role of manufacturing within a society. It is not wellsuited for making international comparisons of the impact of the manufacturing sector.

For international comparisons of the economic impact, the absolute output and the productivity of a national economy are of crucial relevance. In this context, $\underline{\text { absolute employment figures are the reference parameter while relative }}$ employment is of minor interest.

Current definitions of deindustrialization of an economy are (Bryson and Taylor 2008, Lever 1991):

long-term contraction of manufacturing (absolute contraction), a shift from manufacturing to services (relative contraction). 
Both can be measured either in terms of employment or output. The resulting four indicators (Table 1) do not necessarily correlate. With rising productivity, the manufacturing output may increase at the same time as employment declines (def. 1a fulfilled, 1b not fulfilled). Moreover, in a growing economy, absolute growth can go along with a relative decline of the manufacturing sector (def. 1 not fulfilled, def. 2 fulfilled).

From this starting point, Przywara (2016) constituted rigid macroeconomic definitions and utilized them in two complementary models of deindustrialization. These models were tested by macro-economic data for 12 mature and 25 emerging countries, covering the years 1973-2008 with successive $15+5+15$-year sub-periods. The novel scenario model of sectoral development, involving (human) labour content as a central indicator, was introduced by Przywara (2017).

Table 1. Four Standard Indicators for Deindustrialization

\begin{tabular}{|l|c|c|}
\hline & (a) Employment & (b) Output \\
\hline $\begin{array}{l}\text { 1. Absolute contraction of } \\
\text { the manufacturing sector }\end{array}$ & (1a) Declining absolute value & $\begin{array}{l}\text { (1b) Declining absolute value } \\
\text { (CU at constant prices) }\end{array}$ \\
\hline $\begin{array}{l}\text { 2. Relative contraction of } \\
\text { the manufacturing sector }\end{array}$ & (2a) Declining sectoral share & $\begin{array}{l}\text { (2b) Declining relative value } \\
\text { (sectoral share) }\end{array}$ \\
\hline
\end{tabular}

\section{Prediction of the Tipping Point of Relative Manufacturing Employment}

Rowthorn (1994) tried to predict the tipping point of relative manufacturing employment by relating it to the income level (GDP per capita) of a national economy. The underlying assumption of his theory is the continuously rising welfare of a country, driven by the manufacturing sector. In the course of a constant thrive for increased output, productivity is enhanced by automation. When at a certain point in time a specific critical productivity is reached, increases in output will not lead to hiring more employees but to invest in equipment. Thus, the tipping point of employment is reached. In line with societal and industrial development over time and rising productivity, the tipping point at which deindustrialization starts should be related to a certain income per capita.

Rowthorn (1994) predicted an inverted-U relationship between income per capita and the share of manufacturing employment. By regression analysis, he calculated the tipping point at which deindustrialization starts. He estimated tipping at around 12,000 USD (1990 prices), roughly equal to 18,000 USD (2010 prices), resulting in a log value of 9.8. Rowthorn's regression revealed a tipping point manufacturing employment rate of about $22 \%$.

Palma (2005) tested Rowthorn's idea thoroughly and generally confirmed his hypothesis (Figure 2). Yet, Palma realized that things were not as simple as Rowthorn expected, since he found the tipping point to be moving over time. Palma found tipping points moving towards less manufacturing employment and GDP per capita. 
Figure 2. Palma's Findings for ME (\%) vs. GDP per Capita (log)

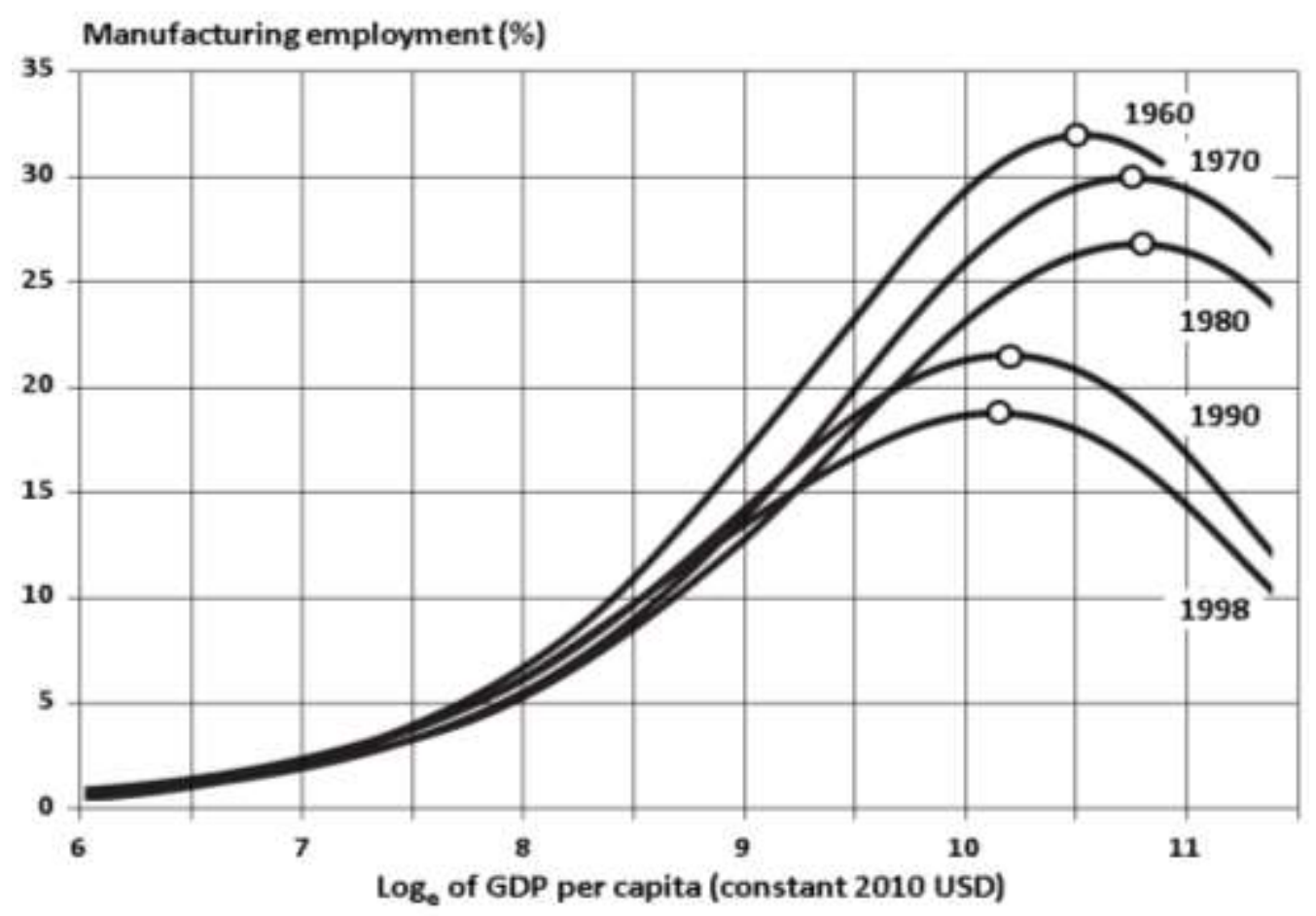

Source: Based on Palma (2005: 77), author's calculations.

A moving tipping point of the regressions had already been predicted by Rowthorn and Wells (1987). They attributed the decline to the rapid productivity growth in (at least some sectors of) manufacturing, brought about by the propagation of the new technological paradigm of microelectronics (Palma 2005). Because productivity catch-up is fastest in manufacturing, in developing countries deindustrialization would start at a lower level of income per capita than in the early industrialized countries (Rowthorn and Wells 1987). Still, the magnitude of the shift was surprising to Palma (Palma 2005).

\section{Identified Gaps of Knowledge and Theory}

Two main gaps of knowledge and theory were identified:

The influence of productivity growth on the tipping point has been assumed by Rowthorn and Wells (1987) and diagnosed by Palmer (2005). Yet, a comprehensive understanding of the relation of manufacturing productivity, maximum sectoral employment and income per capita has not been achieved. Productivity was not included as a variable in the given research.

In the existing investigations on the tipping point of manufacturing, national economies were considered as closed, thus following a similar development pattern with a country-specific time shift. Possible 
interdependencies of countries and the role of firms in international value streams were not taken into account so far.

The research carried out aimed at closing these gaps.

\section{Methodology}

The analysis was carried out with regard to the long-term developments in mature and emerging states. All monetary values were transferred into 2010 US dollars on the basis of exchange rates as utilized by the World Bank (2014a) to assure international comparability over time. For the given purpose, it was found adequate to abstain from the use of purchasing power parities. Utilizing the plain exchange rate

is the "simplest option" (Maddison 1995: 97),

was found to be sufficing since this analysis is mainly on structural shifts within an economy,

is the adequate method for following trade flows,

does not lead to big errors because, in general, the parity has converged over time for the examined mature country group.

The timeframe for the underlying analysis (Przywara 2016) was the period from 1970 until 2010. This period exactly meets the frame set by a statistical database that resulted from an EU research project, the EU KLEMS database (Groningen Growth and Development Centre 2012). It aims at providing a statistical base for questions related to growth and productivity. Its accounts follow the ISIC 4 classification, with special attention to section $\mathrm{C}$ (manufacturing), equalling section D (ISIC 3) and section 3 (ISIC 2) of previous codes (European Commission 2014, United Nations 2002, United Nations 2008). Additional data on the developments before 1970 was gathered from national statistical bureaus and publications.

Data for emerging states was taken from World Bank (2014a) and ILO (2014) statistics. In a number of cases, incomplete data had to be replenished by inter- and extrapolation (for details see Przywara 2016).

\section{Country Sample Selection and Data Processing}

The underlying doctoral thesis (Przywara 2016) comprises economic analyses of 12 mature (high income) and 25 emerging countries. The grouping of countries was carried out in accordance with the World Bank classification (cf. Table 2), based on GNI comparisons. GNI is defined as "the sum of a country's gross domestic product (GDP) and net income (labour compensation and property income) from abroad" (World Bank 2011). For the major industrial countries, the GNI is only very slightly $(<1 \%)$ above their GDP, so for practical reasons, the 
more common GDP will be taken into consideration for grouping the countries according to national income per capita.

Table 2. World Bank Classification of Countries

\begin{tabular}{|l|c|c|c|c|}
\hline \multirow{2}{*}{$\begin{array}{l}\text { Indicator } \\
\text { Economy group }\end{array}$} & $\begin{array}{c}\text { minimum } \\
\text { (USD) }\end{array}$ & $\begin{array}{c}\text { maximum } \\
\text { (USD) }\end{array}$ & $\begin{array}{c}\log _{\mathrm{e}} \text { of } \\
\text { minimum }\end{array}$ & $\begin{array}{c}\log _{\mathrm{e}} \text { of } \\
\text { maximum }\end{array}$ \\
\hline Low income & 0 & 1,005 & & 6.91 \\
\hline Lower-middle income & 1,006 & 3,975 & 6.91 & 8.29 \\
\hline Upper-middle income & 3,976 & 12,275 & 8.29 & 9.42 \\
\hline High income & 12,276 & & 9.42 & \\
\hline
\end{tabular}

Source: World Bank (2011), author's calculations. In constant 2010 USD.

The line between emerging and mature economies will be drawn along the line of high-income countries for two reasons:

According to the World Bank, low-income and middle-income economies are sometimes referred to as developing countries, so this would exactly be the opposite of a mature country.

It fits well with Rowthorn's and Palma's findings on the tipping point for deindustrialization of mature economies. These are always well above the high-income threshold (cf. Table 3).

A list of the examined mature countries is given in Table 3.

Table 3. List of Analysed Mature Economies and Some Key Features (2010)

\begin{tabular}{|l|c|r|r|r|r|}
\hline \multirow{2}{*}{ Country } & \multirow{2}{*}{$\begin{array}{c}\text { Indicator } \\
\text { Code }\end{array}$} & Population & Pop. density & GDP & GDP p/c \\
\cline { 3 - 6 } & (million) & $(\# \text { per km })^{2}$ & $($ bn USD) & (k USD) \\
\hline Austria* & $\boldsymbol{A U T}$ & 8.4 & 101.8 & 377.7 & 45.0 \\
\hline Belgium* & $\boldsymbol{B E L}$ & 10.9 & 360.6 & 471.1 & 43.2 \\
\hline Finland* & $\boldsymbol{F I N}$ & 5.4 & 17.6 & 236.7 & 44.1 \\
\hline France* & $\boldsymbol{F R A}$ & 65.0 & 118.7 & $2,565.0$ & 39.4 \\
\hline Germany* & DEU $(\boldsymbol{G E R})$ & 81.8 & 234.6 & $3,304.4$ & 40.4 \\
\hline Italy* & $\boldsymbol{I T A}$ & 60.5 & 201.5 & $2,055.4$ & 34.7 \\
\hline Japan & $\boldsymbol{J P N}$ & 127.5 & 349.7 & $5,495.4$ & 43.1 \\
\hline Netherlands* & $\boldsymbol{N L \boldsymbol { D }}$ & 16.6 & 492.6 & 777.2 & 46.8 \\
\hline Spain* & $\boldsymbol{E S P}$ & 46.6 & 93.4 & $1,384.8$ & 29.7 \\
\hline Sweden & $\boldsymbol{S W E}$ & 9.4 & 22.9 & 462.9 & 49.4 \\
\hline UK & $G B R(\boldsymbol{U K})$ & 62.7 & 259.4 & $2,285.5$ & 36.6 \\
\hline USA & $\boldsymbol{U S A}$ & 309.3 & 33.8 & $14,958.3$ & 48.4 \\
\hline
\end{tabular}

Source: World Bank (2014a) data and codes (in brackets: codes utilized in this article), in constant 2010 USD. * Eurozone country

Industrialization and eventual deindustrialization in emerging economies is examined for a sample of countries from three regions, following the World Bank (2014b) grouping: 
Vol. 5, No. 2 Przywara: The Interrelation between Manufacturing Productivity...

Latin America,

East Europe and Central Asia,

East Asia.

A list of these countries is rendered by Table 4. By the end of the examined period, several countries have made a successful transition into the high-income group. Most clear examples are the Czech Republic, the Slovak Republic and especially (South) Korea.

Table 4. Analysed Emerging Economies Including Key Features (2010 Data)

\begin{tabular}{|c|c|c|c|c|c|}
\hline \multirow[t]{2}{*}{ Country } & \multirow{2}{*}{$\begin{array}{l}\text { Indicator } \\
\text { Code }\end{array}$} & Population & $\begin{array}{c}\text { Population } \\
\text { density }\end{array}$ & GDP & $\begin{array}{c}\text { GDP } \\
\text { per capita }\end{array}$ \\
\hline & & (million) & $($ per km²) & (bn USD) & (k USD) \\
\hline \multicolumn{6}{|c|}{ Latin America } \\
\hline Argentina & $A R G$ & 40.4 & 14.8 & 368.7 & 9.1 \\
\hline Brazil & $B R A$ & 195.0 & 23.1 & $2,143.0$ & 11.0 \\
\hline Chile & CHL & 12.5 & 23.1 & 217.6 & 12.7 \\
\hline Colombia & COL & 46.4 & 41.9 & 287.0 & 6.2 \\
\hline Ecuador & $E C U$ & 15.0 & 60.4 & 67.5 & 4.5 \\
\hline Mexico & MEX & 117.9 & 60.6 & $1,047.4$ & 8.9 \\
\hline Venezuela & VEN & 29.0 & 32.9 & 393.8 & 13.6 \\
\hline \multicolumn{6}{|c|}{ East Europe \& Central Asia } \\
\hline Bulgaria & $\boldsymbol{B} \boldsymbol{U} \boldsymbol{L}$ & 7.4 & 68.1 & 47.7 & 6.5 \\
\hline Croatia & $H R V(\boldsymbol{C R O})$ & 5.4 & 78.9 & 58.9 & 10.9 \\
\hline Czech Republic & $C Z E$ & 10.5 & 135.6 & 198.5 & 18.9 \\
\hline Kazakhstan & $K A Z$ & 16.3 & 6.0 & 148.1 & 9.1 \\
\hline Poland & $P O L$ & 38.2 & 125.5 & 469.7 & 12.3 \\
\hline Romania & ROM & 20.2 & 88.0 & 164.8 & 8.1 \\
\hline Russia & $\boldsymbol{R U S}$ & 142.4 & 8.7 & $1,524.9$ & 10.7 \\
\hline Serbia & $S R B$ & 7.3 & 83.4 & 37.0 & 5.1 \\
\hline Slovak Republic & SVK & 5.4 & 112.1 & 87.1 & 16.2 \\
\hline Turkey & TUR & 72.1 & 93.7 & 731.1 & 10.1 \\
\hline Ukraine & $U K R$ & 45.9 & 79.2 & 136.4 & 3.0 \\
\hline \multicolumn{6}{|c|}{ East Asia } \\
\hline China & CHN & $1,337.7$ & 143.4 & $5,930.5$ & 4.4 \\
\hline India & $I N D$ & $1,205.6$ & 405.5 & $1,708.5$ & 1.4 \\
\hline Indonesia & $I D N$ & 240.7 & 132.9 & 709.2 & 2.9 \\
\hline Korean Republic & KOR & 49.4 & 508.9 & $1,014.9$ & 20.5 \\
\hline Malaysia & MYS & 28.3 & 86.1 & 247.5 & 8.8 \\
\hline Thailand & $T H A$ & 66.4 & 130.0 & 318.9 & 4.8 \\
\hline Vietnam & $V N M$ & 86.9 & 280.4 & 115.9 & 1.3 \\
\hline
\end{tabular}

Source: Based on World Bank (2014a) data and codes (in brackets: codes utilized in this article) 


\section{Results}

This section contains three main elements:

Detailed analysis of deindustrialization of the group of 12 mature countries Per region analysis of the industrial development of 25 emerging states

Combination of the key findings for both groups.

\section{Findings for Mature Countries}

Rowthorn's (2014) theory on the course of economic maturing processes was tested for all economies of the sample. The share of employment in manufacturing was calculated as a variable depending on GDP per capita $\left(\log _{e}\right.$ of constant 2010 USD).

The expectation was that mature economies in the period 1970-2010 would be able to constantly increase their income per capita. Over time, they should move from the left to the right side of the graph. Concerning the share of manufacturing, they will show one of the following types of behaviour:

Very rich and mature countries, first of all the USA, should have already passed the tipping point predicted by Rowthorn. Thus, a constant decline of the share of manufacturing employment should result over time and increasing income per capita.

Some of the fairly rich countries may not have reached their tipping point by 1970 . For the first years, there is a parallel increase of manufacturing employment and GDP.

If the maximum employment point occurs at a GDP per capita of around 18.000 USD (2010 prices), as Rowthorn calculated, or at even higher values, as Palma (2005) determined, this is clearly above the entrance criterion for a highincome economy.

\section{Courses of Deindustrialization}

Key indicators for deindustrialization are summarized in Table 5. Given the GDP per capita for 1970, only Sweden, the USA and the Netherlands were clearly above the tipping point predicted by Rowthorn (1994), while in all other cases, both kinds of behaviour could have been possible. Spain was just short over the edge of being a high-income country, with a level of maturity clearly below that of all other economies of the sample

1970 to 2010 plots for manufacturing employment over GPD per capita (log) are given in Figure 3 (countries with a constant decrease in manufacturing employment, i.e. tipping before 1970) and Figure 4 (countries with a tipping point). Countries showing similar behaviour (constant decrease versus tipping point) were each grouped in one graph. 
Table 5. Key Data for Mature Countries

\begin{tabular}{|c|c|c|c|c|c|c|c|c|c|c|c|c|c|}
\hline \multicolumn{2}{|r|}{ Country } & AUT & BEL & FIN & FRA & ESP & GER & ITA & JPN & NED & SWE & UK & USA \\
\hline \multirow{3}{*}{$\begin{array}{l}\text { Manufacturing } \\
\text { employment } \\
(\%)\end{array}$} & 1970 & 25.1 & 31.8 & 24.6 & 23.6 & 21.4 & 34.3 & 26.8 & 25.5 & 22.8 & 27.8 & 24.6 & 23.5 \\
\hline & 2010 & 14.6 & 12.3 & 15.4 & 10.9 & 20.8 & 17.3 & 18.2 & 15.7 & 9.8 & 13.4 & 7.1 & 8.8 \\
\hline & CAGR & -1.41 & -2.42 & -1.10 & -2.02 & -1.67 & -1.66 & -0.98 & -1.20 & -2.14 & -1.57 & -3.06 & -2.36 \\
\hline \multirow{3}{*}{$\begin{array}{l}\text { GDP per capita } \\
\text { (k USD) }\end{array}$} & 1970 & 18.8 & 20.1 & 18.0 & 20.1 & 13.3 & 18.9 & 22.9 & 17.9 & 22.5 & 25.1 & 16.3 & 23.3 \\
\hline & 2010 & 45.0 & 43.2 & 44.1 & 39.4 & 29.7 & 40.4 & 34.0 & 43.1 & 46.8 & 49.4 & 36.4 & 48.4 \\
\hline & CAGR & 2.19 & 1.87 & 2.33 & 1.64 & 2.03 & 1.90 & 1.82 & 2.07 & 1.93 & 1.80 & 2.13 & 1.86 \\
\hline \multicolumn{2}{|r|}{ Tipping year } & 1972 & 1970 & 1974 & 1974 & 1977 & 1967 & 1980 & 1973 & 1961 & 1965 & 1966 & 1953 \\
\hline \multirow{2}{*}{ Manufacturing } & employment (\%) & 25.6 & 31.8 & 25.2 & 24.2 & 22.6 & 37.9 & 28.2 & 25.8 & 26.3 & 31.9 & 28.3 & 32.1 \\
\hline & $\begin{array}{l}\text { productivity } \\
\text { (USD/h) }\end{array}$ & 24,1 & 23,2 & 23,6 & 26,8 & 31,8 & 20,4 & 33,5 & 23,9 & 18,1 & 19,4 & 15,3 & 16,4 \\
\hline \multirow{2}{*}{ GDP } & per capita (k USD) & 20.8 & 20.1 & 21.5 & 23.8 & 15.7 & 14.5 & 23.6 & 21.2 & 15.0 & 21.4 & 14.9 & 16.2 \\
\hline & $\log _{\mathrm{e}}$ & 9.94 & 9.91 & 9.98 & 10.08 & 9.66 & 9.56 & 10.04 & 9.96 & 9.61 & 9.97 & 9.61 & 9.69 \\
\hline
\end{tabular}

Sources: World Bank (2014a), Bach \& Riefers (1970), Statistika Centralbyran (1970), Federal Reserve Bank of St. Louis (2018), author's calculations. In constant 2010 USD. 
Figure 3. Manufacturing Employment (\%) vs. GDP p/c $\left(\log _{e}\right)$; Mature States Beyond Tipping

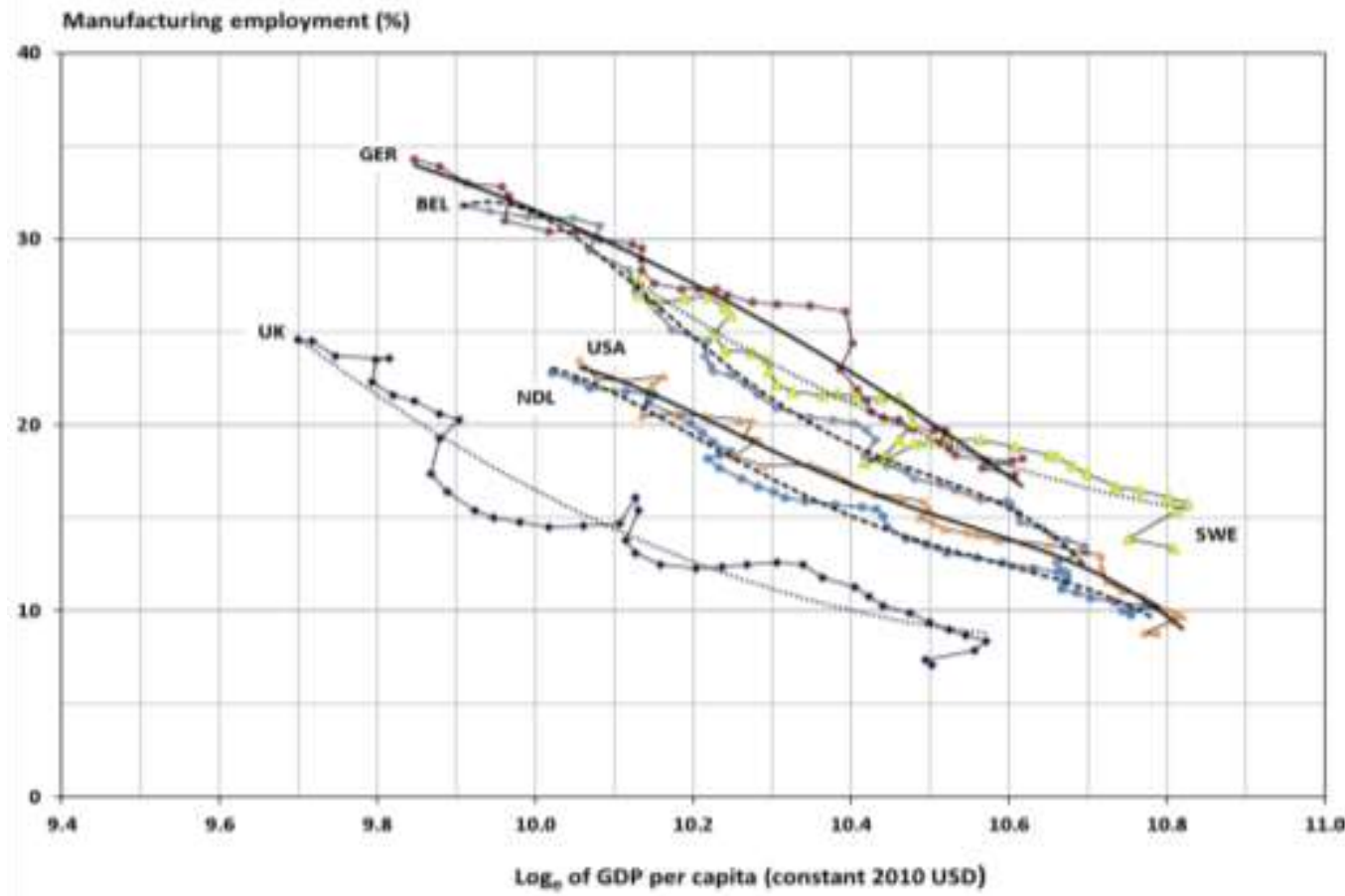

Sources: Author's calculations, based on Groningen Growth and Development Centre (2012) and World Bank (2014a) data. Data for 1970-2010, polynomial trends

Figure 4. Manufacturing Employment (\%) vs. GDP p/c $\left(\log _{e}\right)$; Mature States with Tipping Points

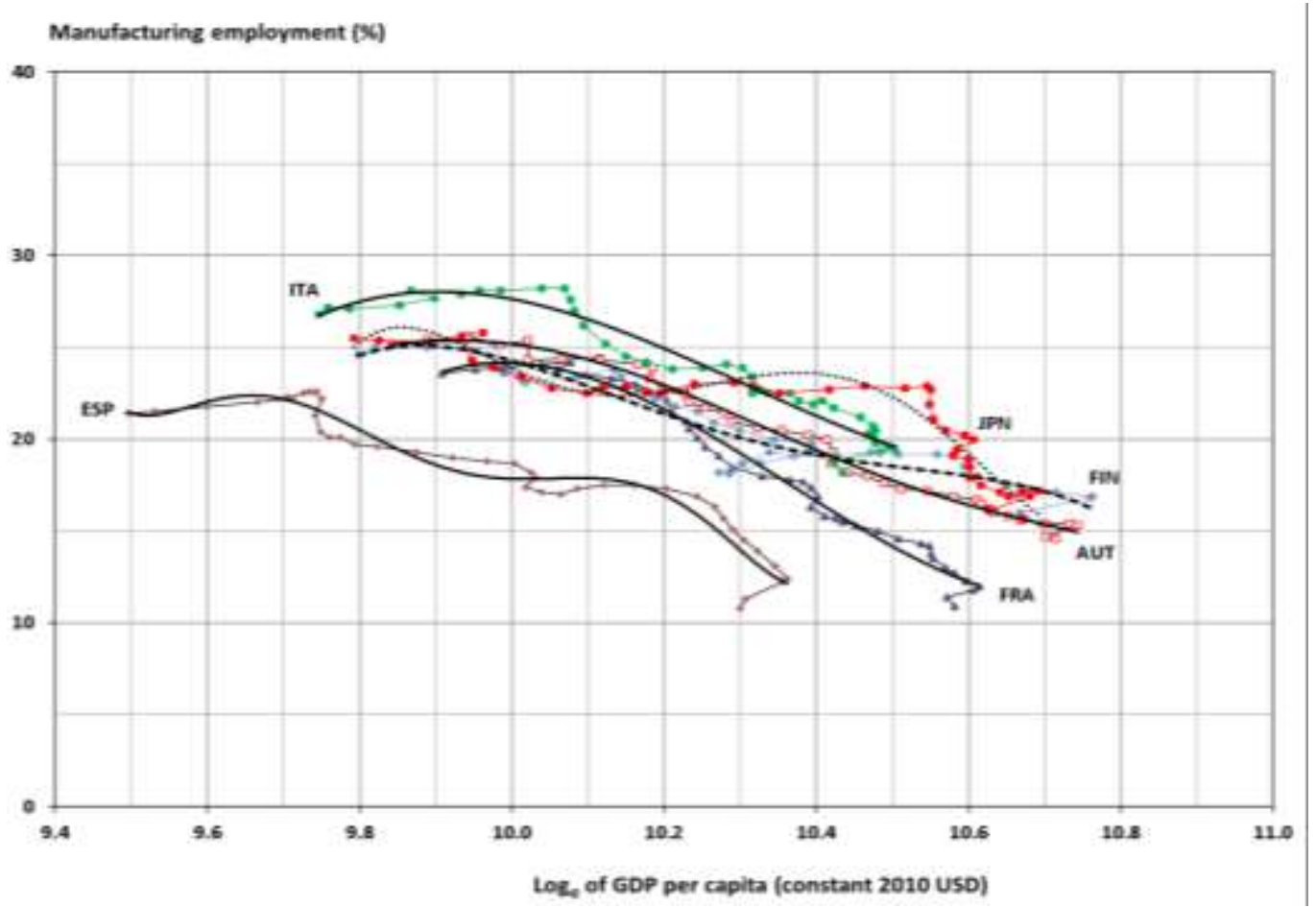

Sources: Author's calculations, based on Groningen Growth and Development Centre (2012) and World Bank (2014a) data. Data for 1970-2010, polynomial trends 
The left half of the expected inverted-U shape over time is not present by definition in the group of countries with a continuous decrease in manufacturing. This left half is almost invisible also for the tipping point group. In these cases, the 1970 values for manufacturing employment were already close to the maximum level reached a few years later. In the special case of Belgium, the tipping point was exactly reached in 1970 .

Spain had reached a comparatively little level of maturity in 1970. Given Rowthorn's assumptions, Spain should have stayed on a growth path concerning manufacturing, but, as Figure 4 shows, it was not able to follow this path consequently. This might partially be attributed to national developments, but can also be attributed to more general observations which will be outlined in the following.

\section{Tipping Points}

The tipping points of mature economies from 1970 to 1980 are quite similar, concerning GDP per capita (cf. Table 5). By involving all alike mature countries with a tipping point, i.e. including Belgium but excluding Spain, a trend line for the structural shift of mature economies was derived as displayed in the following graph (Figure 5) from a polynomial regression analysis.

Figure 5. Joint Regression Analysis of Tipping Mature Economies

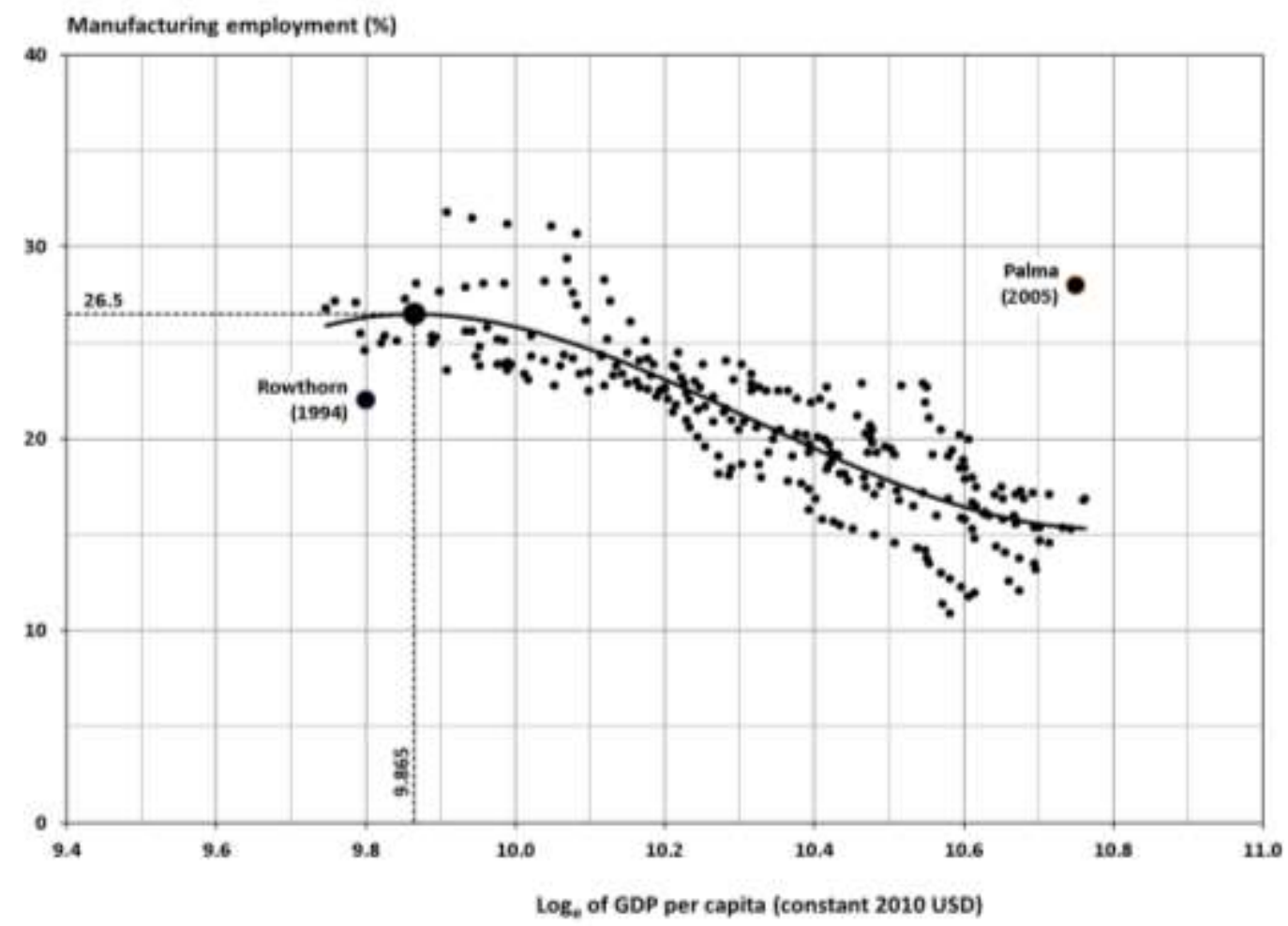

Sources: Author's calculations, based on Groningen Growth and Development Centre (2012) and World Bank (2014a) data for Austria, Belgium, Finland, France, Italy, Japan; Palma (2005). Regression: $3^{\text {rd }}$ degree polynomial. 
The average maximum manufacturing employment stood at $26.5 \%$, the GDP per capita around $21.7 \mathrm{k}$ USD $(\log \approx 9.9)$. This is somewhat higher than Rowthorn's (1994), but much lower than Palma's (2005) results for the 1970s.

The findings cast a certain doubt on some findings of Palma's (2005) analysis. In accordance with his interpretation, there is evidence that there is a shift over time towards lower tipping points in terms of manufacturing employment, but there is none towards a lower national income per capita.

\section{Industrial development of 25 emerging states}

Analogously to the analysis of mature countries, the interrelation of manufacturing employment and national wealth as income per capita was analysed. The plots for manufacturing employment over GDP per capita $\left(\log _{\mathrm{e}}\right)$ differ in the range of the GDP displayed, corresponding to national wealth. While for mature countries, a log range between $9.4(\sim 12.1 \mathrm{k}$ USD) and $11.0(\sim 59.9 \mathrm{k}$ USD) was adequate, meaning that all of the countries were permanently located in the World Bank high-income group, emerging countries were (and most of them still are) much poorer. The adequate range for Latin-American and East European countries was between $7.4(\sim 1.6 \mathrm{k}$ USD) and $10.0(\sim 22.0 \mathrm{k}$ USD) while some East Asian states required to extend the range to the left down to $5.4(\sim 0.3 \mathrm{k}$ USD), meaning that people lived on less than one USD per day at average.

Respective graphs are given by Figures 6-8, describing the course of development of manufacturing employment over national income per capita. These are mostly related to growing national income per capita, rendering the following graph shapes:

Inverted U-shape: industrialization and subsequent deindustrialization U-shape: (mild) deindustrialization and subsequent recovery

$\rightarrow$ : constant share of manufacturing employment, rising productivity

There are some forms related to stagnation or (temporal) loss of national income per capita:

C-shape: reverse deindustrialization (income losses), turning into subsequent deindustrialization with income recovery). Note: The C-shape cycle ends when the initial income per capita (in constant prices) is reached again.

Inverted C-shape: continuous deindustrialization, starting with gains in income per capita, then waning, finally turning into income losses.

In the following, the regional results are summarized briefly per region.

\section{$\underline{\text { Latin America }}$}

The results for Latin America are shown in Figure 6. At first glance, no clear tendency and also no reverse U-shape curves including tipping points expected by the classical economists can be traced. In all states, the share of manufacturing 
employment was most of the time in a very small range between $10 \%$ and $20 \%$ of total employment. In 2010, the investigated economies only had a tiny bandwidth from $11.5 \%$ (Venezuela) to $16.5 \%$ (Mexico) of manufacturing employment.

The values for Latin America are divided into two major phases. In the first phase until around the year 2000, negative deindustrialization (i.e. including welfare losses) prevailed. More recently, there has been industrial development (inverted U-shape, $\rightarrow$ ) or at least on going recovery (C-shape).

Figure 6. $M E(\%)$ vs. GDP p/c (log), Latin America

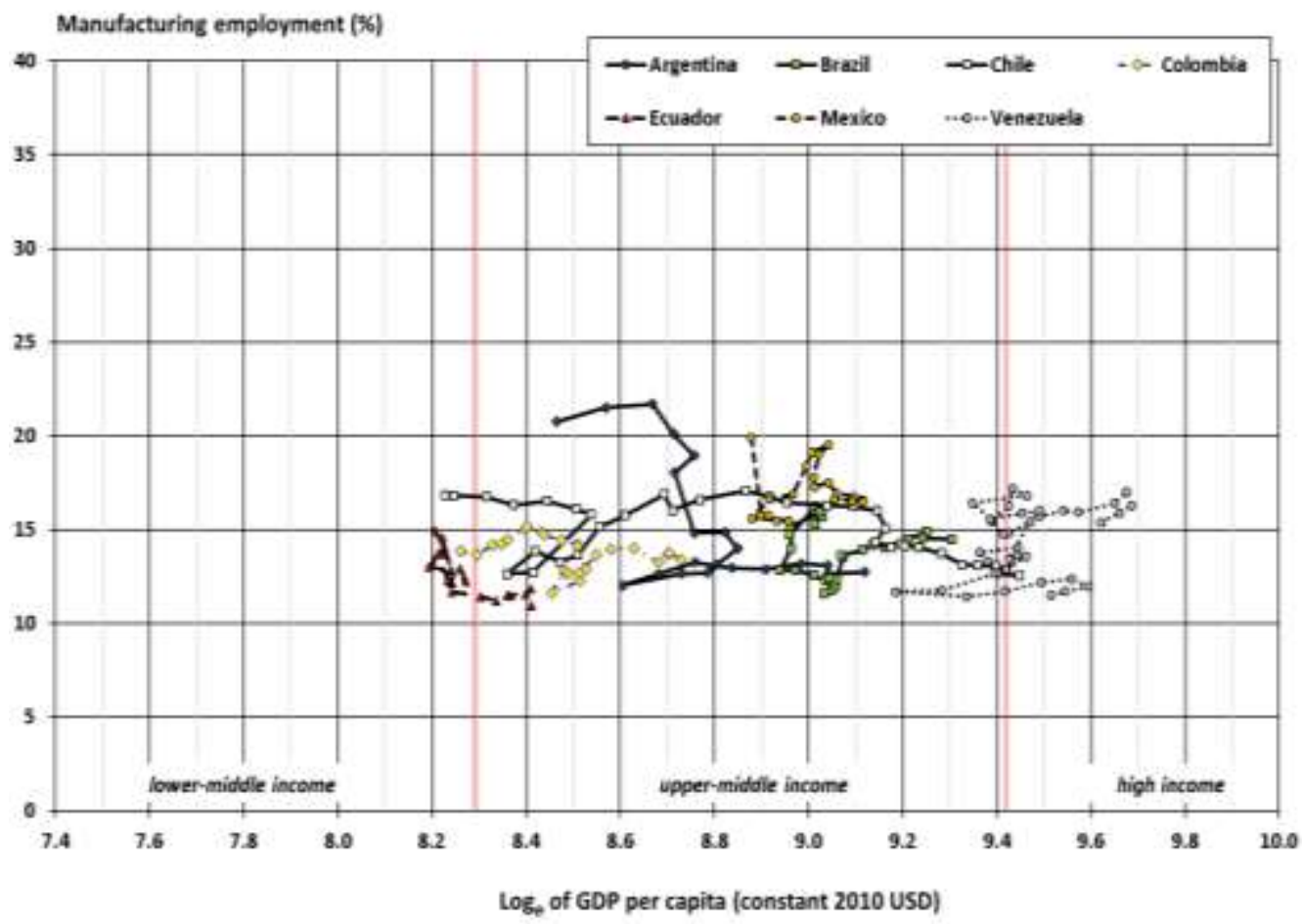

Sources: Author's graph, ILO (2014) and World Bank (2014a) data until 2010, starting in 1975 (CHL, VEN), 1985 (BRA), 1990-2010 (ARG, COL, ECU, MEX)

\section{East Europe and Central Asia}

The results for East Europe and Central Asia are shown in Figure 7. Compared to the Latin-American results, the bandwidth is much larger, also concerning the shapes of the curves. C-shape curves are not rare. No classical inverted U-shape curves can be traced, only some left or right 'legs' of the U letter. Turkey, the only former non-communist country, is an exception within the investigated group, pursuing a constant industrial development (inverted U-shape).

The investigated former communist states all went through a crisis (C-shape) but have all managed to recover and keep the remains of their industrial base constant $(\rightarrow)$, apart from Serbia with its fast-eroding manufacturing base and the Ukraine somewhat lagging behind (both still C-shape). 
Figure 7. $M E(\%)$ vs. GDP p/c (log), East Europe and Central Asia

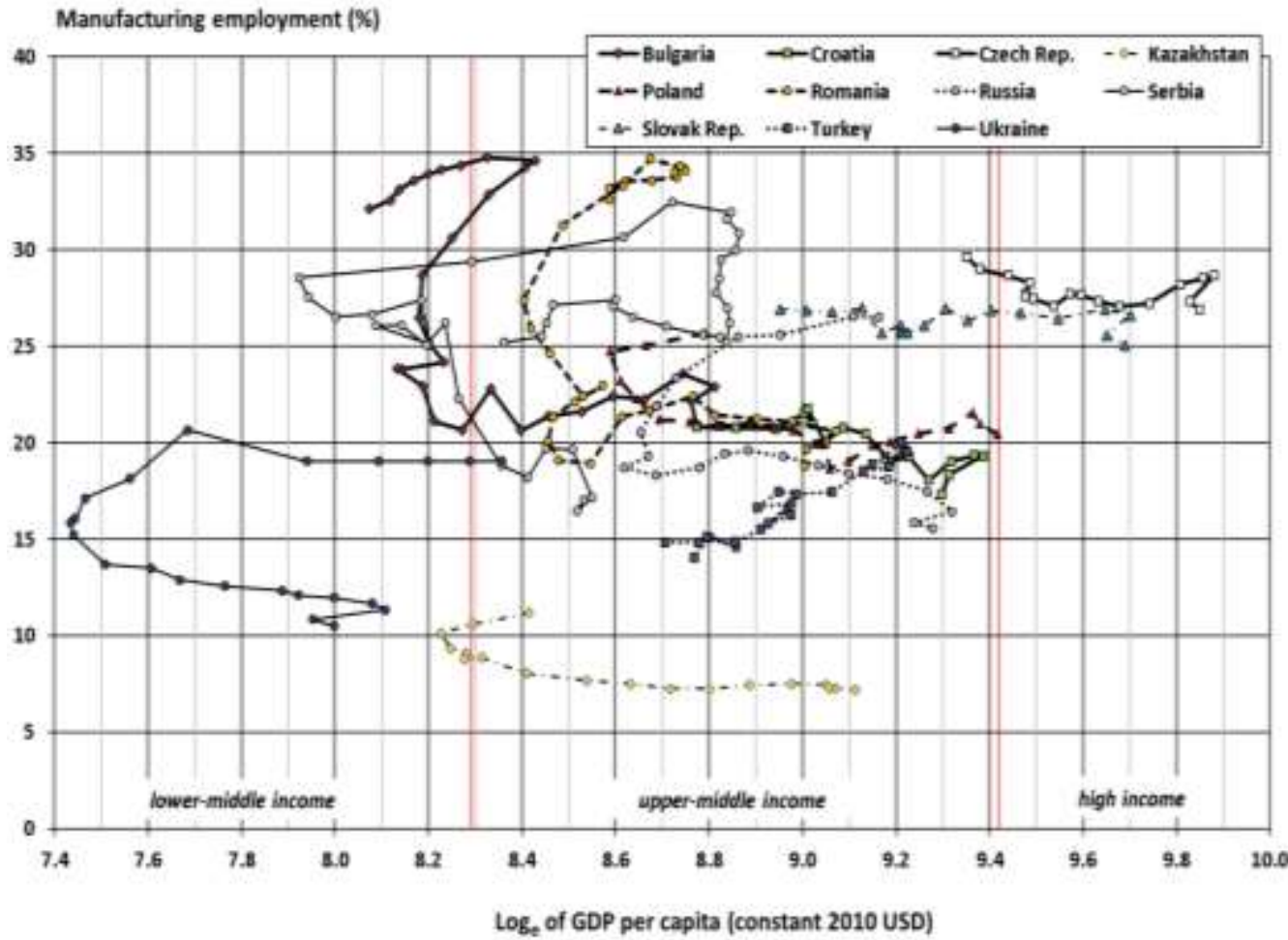

Sources: Author's graph, ILO (2014) and World Bank (2014a) data until 2008; starting in 1970 (SRB); 1980 (BUL, ROM); 1989 (POL, UKR, TUR), 1990 (RUS), 1991 (CRO), 1993 (CZE, KAZ, SVK)

Although being much less productive than Western states, very highly industrialized states in East Europe reached peaks in manufacturing employment shortly before or in 1990, as the examples of Bulgaria, Romania and Serbia (ExYugoslavian federal state) illustrate.

\section{$\underline{\text { East Asia }}$}

The results for East Asia are shown in Figure 8. In all of these states apart from China $(\rightarrow)$, industrial development follows, at least partly, the course predicted by 20th century economists (inverted U). In the cases of South Korea and Malaysia, even almost classical inverted U-shape curves can be seen.

By this form of catch-up modernization, East Asia made significant economic progress. China has become the 'workshop of the world' without altering the size of its workforce in manufacturing, but on the basis of its giant population and immense progress in productivity. 
Figure 8. $M E(\%)$ vs. GDP p/c (log), East Asia

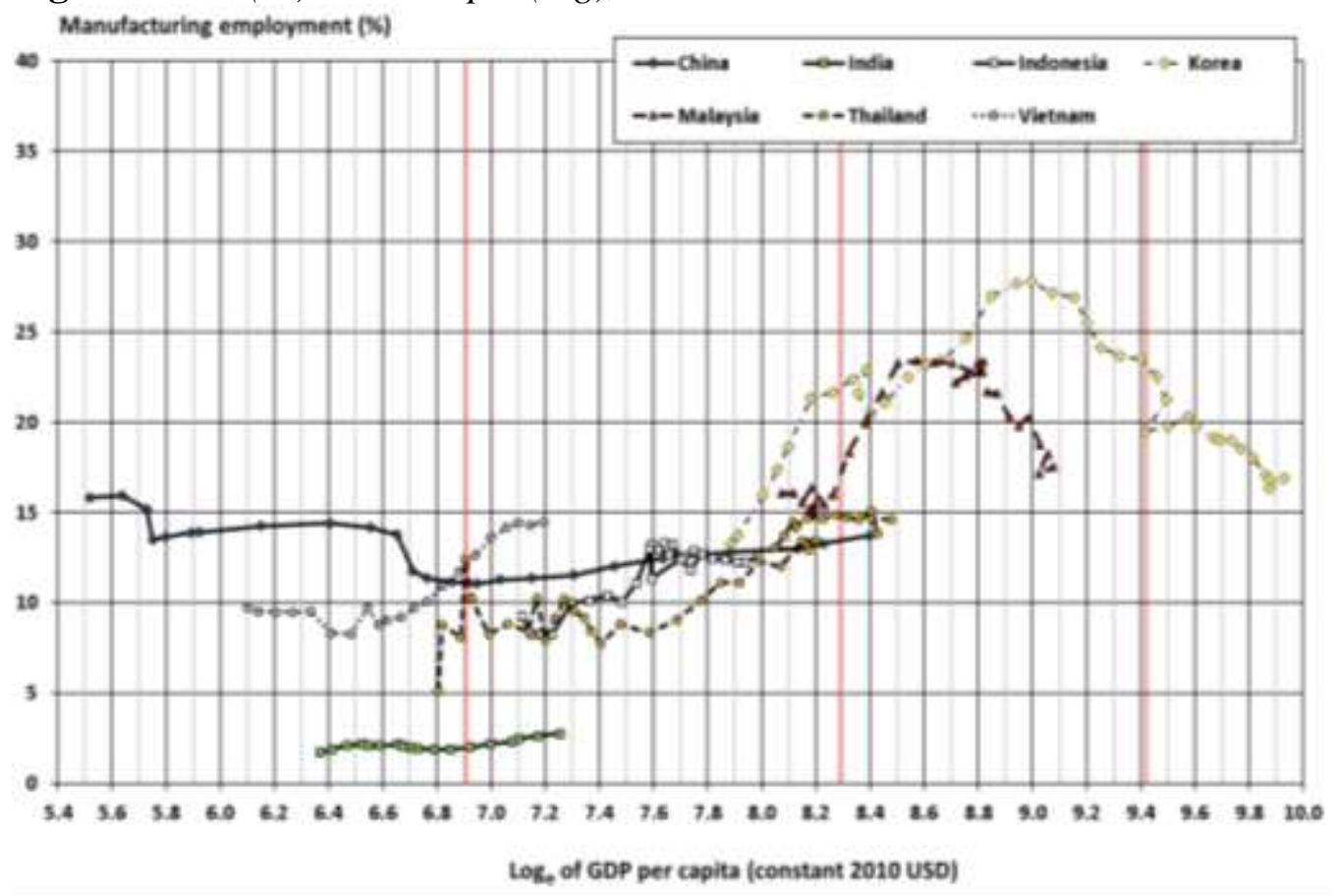

Sources: Author's graph, ILO (2014) and World Bank (2014a) data until 2010, starting in 1970 (KOR), 1971 (THA), 1980 (MYS), 1985 (IDN), 1987, (CHI), 1990 (VNM), 1993 (IND, w/o informal economy).

\section{$\underline{\text { Key Findings for Emerging Countries }}$}

The interpretations of the detected phenomena are compiled in Table 6. Eight states have reached their maximum level of manufacturing employment over the investigated period. 
Table 6. Industrial Development Processes in Emerging Countries

\begin{tabular}{|c|c|c|c|c|c|c|c|c|c|}
\hline \multirow[t]{2}{*}{ Country } & \multirow{2}{*}{\begin{tabular}{|l} 
Start \\
Year \\
\end{tabular}} & \multicolumn{2}{|c|}{$\begin{array}{l}\text { Income } \\
\text { group }\end{array}$} & \multicolumn{3}{|c|}{ Curve shape } & \multicolumn{3}{|c|}{ Tipping point } \\
\hline & & Start & 2010 & $\begin{array}{c}\text { Prev. } \\
\text { phases }\end{array}$ & $\begin{array}{l}\text { Tran- } \\
\text { sition }\end{array}$ & $\begin{array}{c}\text { Most } \\
\text { actual } \\
\text { phase }\end{array}$ & Year & $\begin{array}{c}\text { Manuf. } \\
\text { empl. } \\
(\%)\end{array}$ & $\begin{array}{c}\text { GDP } \\
\text { p/c } \\
(\mathbf{k U S D})\end{array}$ \\
\hline \multicolumn{10}{|l|}{ Latin America } \\
\hline Argentina & 1990 & UMI & UMI & inv. C & 2002 & $\rightarrow$ & & & \\
\hline Brazil & 1985 & UMI & UMI & $\mathrm{C}$ & 1999 & inv. $\mathrm{U}$ & $\mathrm{n} / \mathrm{a}$ & & \\
\hline Chile & 1975 & LMI & $\mathrm{HI}$ & inv. $\mathrm{C}$ & 1983 & inv. U & 1992 & 17.1 & 7.1 \\
\hline Colombia & 1985 & UMI & UMI & $\mathrm{n} / \mathrm{a}$ & $\mathrm{n} / \mathrm{a}$ & $\rightarrow$ & & & \\
\hline Ecuador & 1990 & LMI & UMI & $\downarrow$ & 2003 & $\rightarrow$ & & & \\
\hline Mexico & 1990 & UMI & UMI & $\mathrm{U}$ & 2000 & $\mathrm{C}$ & 2000 & 19.5 & 8.5 \\
\hline Venezuela & 1975 & $\mathrm{HI}$ & $\mathrm{HI}$ & $\mathrm{n} / \mathrm{a}$ & $\mathrm{n} / \mathrm{a}$ & $\mathrm{C}$ & & & \\
\hline \multicolumn{10}{|c|}{ East Europe \& Central Asia } \\
\hline Bulgaria & 1980 & LMI & UMI & $\begin{array}{c}\text { inv. U } \\
\mathrm{C}\end{array}$ & $\begin{array}{l}1989 \\
2002 \\
\end{array}$ & $\rightarrow$ & 1987 & 34.8 & 4.1 \\
\hline Croatia & 1991 & UMI & UMI & $\mathrm{n} / \mathrm{a}$ & $\mathrm{n} / \mathrm{a}$ & $\rightarrow$ & & & \\
\hline Czech Rep. & 1993 & UMI & $\mathrm{HI}$ & $\mathrm{n} / \mathrm{a}$ & $\mathrm{n} / \mathrm{a}$ & $\rightarrow$ & & & \\
\hline Kazakhstan & 1993 & UMI & UMI & $\mathrm{C}$ & 2000 & $\rightarrow$ & & & \\
\hline Poland & 1990 & UMI & HI & $\mathrm{C}$ & 2000 & $\rightarrow$ & & & \\
\hline Romania & 1980 & UMI & UMI & $\begin{array}{c}\text { inv. } \mathrm{U} \\
\mathrm{C}\end{array}$ & $\begin{array}{l}1986 \\
2004\end{array}$ & $\rightarrow$ & 1989 & 34.7 & 5.9 \\
\hline Russia & 1990 & UMI & UMI & $\mathrm{C}$ & 2006 & $\rightarrow$ & & & \\
\hline Serbia & 1970 & UMI & UMI & inv. $\mathrm{U}$ & 1987 & $\mathrm{C}$ & 1990 & 32.5 & 6.1 \\
\hline Slovak Rep. & 1993 & UMI & $\mathrm{HI}$ & $\mathrm{n} / \mathrm{a}$ & $\mathrm{n} / \mathrm{a}$ & $\rightarrow$ & & & \\
\hline Turkey & 1990 & UMI & UMI & $\mathrm{n} / \mathrm{a}$ & $\mathrm{n} / \mathrm{a}$ & inv. U & 2008 & 20.0 & 10.0 \\
\hline Ukraine & 1993 & UMI & LMI & $\mathrm{n} / \mathrm{a}$ & $\mathrm{n} / \mathrm{a}$ & $\mathrm{C}$ & & & \\
\hline \multicolumn{10}{|l|}{ East Asia } \\
\hline China & 1987 & $\mathrm{LI}$ & UMI & $\mathrm{n} / \mathrm{a}$ & $\mathrm{n} / \mathrm{a}$ & $\rightarrow$ & & & \\
\hline India & 1993 & LI & LMI & $\mathrm{n} / \mathrm{a}$ & $n / a$ & inv. $U$ & $\mathrm{n} / \mathrm{a}$ & & \\
\hline Indonesia & 1985 & LMI & LMI & $\mathrm{n} / \mathrm{a}$ & $\mathrm{n} / \mathrm{a}$ & inv. U & $\mathrm{n} / \mathrm{a}$ & & \\
\hline Korean Rep. & 1970 & UMI & $\mathrm{HI}$ & $\mathrm{n} / \mathrm{a}$ & $\mathrm{n} / \mathrm{a}$ & inv. $\mathrm{U}$ & 1989 & 27.8 & 8.1 \\
\hline Malaysia & 1980 & LMI & UMI & $\mathrm{n} / \mathrm{a}$ & $\mathrm{n} / \mathrm{a}$ & inv. U & 1997 & 23.4 & 6.8 \\
\hline Thailand & 1971 & LI & UMI & $\mathrm{n} / \mathrm{a}$ & $\mathrm{n} / \mathrm{a}$ & inv. $\mathrm{U}$ & & & \\
\hline Vietnam & 1990 & LI & LMI & $\mathrm{n} / \mathrm{a}$ & $\mathrm{n} / \mathrm{a}$ & inv. $\mathrm{U}$ & & & \\
\hline
\end{tabular}

Sources: Author's analysis, based on ILO (2014) and World Bank (2014a) data. In constant 2010 USD. Groups: LI = low income; LMI = lower-middle income; HMI = upper-middle income; $\mathrm{HI}=$ high income

\section{Combination of the Key Findings for Mature and Emerging States}

Deindustrialization in terms of reductions in relative manufacturing employment was found in all mature countries, but also in certain emerging countries. According to literature (Rowthorn 1994, Palma 2005), the tipping point of manufacturing employment, i.e. the all-time high, is reached at a certain level of national wealth which was supposed to be falling over the years. In fact, the identified relations are somewhat different to these predictions from literature, as will be explicated in the following. 


\section{Comprehensive Evaluation of the Tipping of Mature and Emerging States}

In Figure 9, the identified tipping points of all investigated mature and emerging economies are summarized in one graph.

\section{$\underline{\text { Mature Countries }}$}

Austria, Japan, France, Finland, Spain and Italy tipped in 1972-80 at around $25 \%$ manufacturing employment. Spain was remarkably poorer than the others and was thus considered as an outlier in the calculation of the trend.

Early industrializers like the USA, Germany, Sweden and Belgium tipped at more than $30 \%$ of manufacturing employment.

The manufacturing industry of the Netherlands and the UK also tipped early but never blossomed to the extent that could be expected from the trendline. Thus, both points were qualified as outliers.

Figure 9. Tipping Points of Mature and Emerging Countries

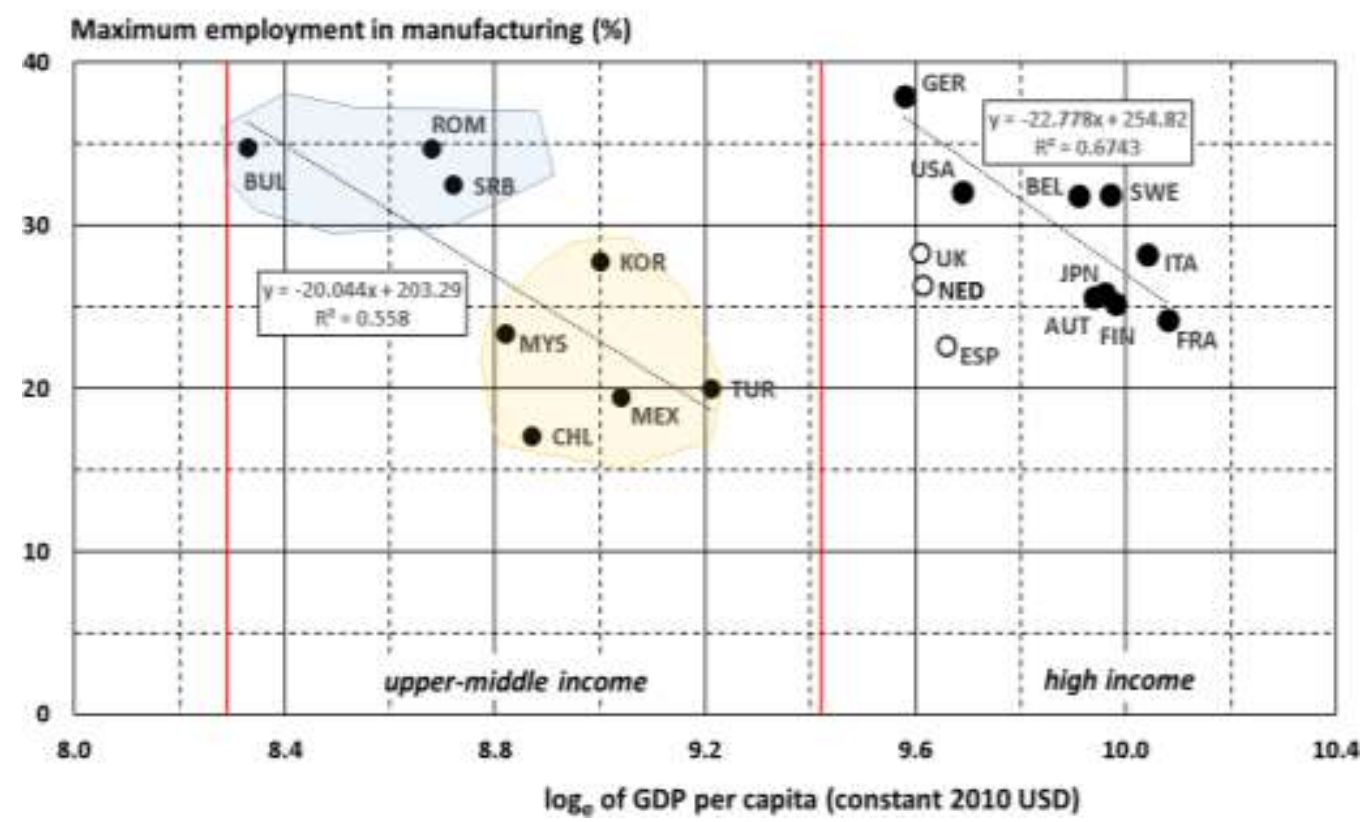

Source: Author's graph, based on ILO (2014) and World Bank (2014a) data, linear trends. Two groups are identified:

\section{Emerging Countries}

The former socialist countries Bulgaria, Serbia and Romania tipped in the late 1980 s at about $35 \%$ manufacturing employment.

The catch-up modernizers Korea, Chile, Malaysia, Mexico and Turkey tipped in the last two decades under investigation at around $20 \%$.

Both sub-groups are characterized by far less national wealth than the mature states. When united in one group, there is a trend line approximately parallel to the one of mature states. 


\section{$\underline{\text { Key Findings }}$}

Two almost parallel falling linear functions of maximum manufacturing employment $(\%)$ over GDP per capita $(\log )$ were identified for mature and emerging countries. In both cases, the tipping point moves over time from high to low manufacturing employment and from low to high income. The functions are clearly separated; hence the income differences between both identified groups are large.

\section{Analysis of the Threshold Productivity for Tipping}

Since manufacturing productivity is a key driver of national wealth and structural change (see above), the manufacturing productivity reached at the tipping points of manufacturing employment was analysed. This critical productivity of manufacturing is displayed in Figure 10 over time.

Figure 10. Manufacturing Productivity over Time, Mature and Emerging Countries

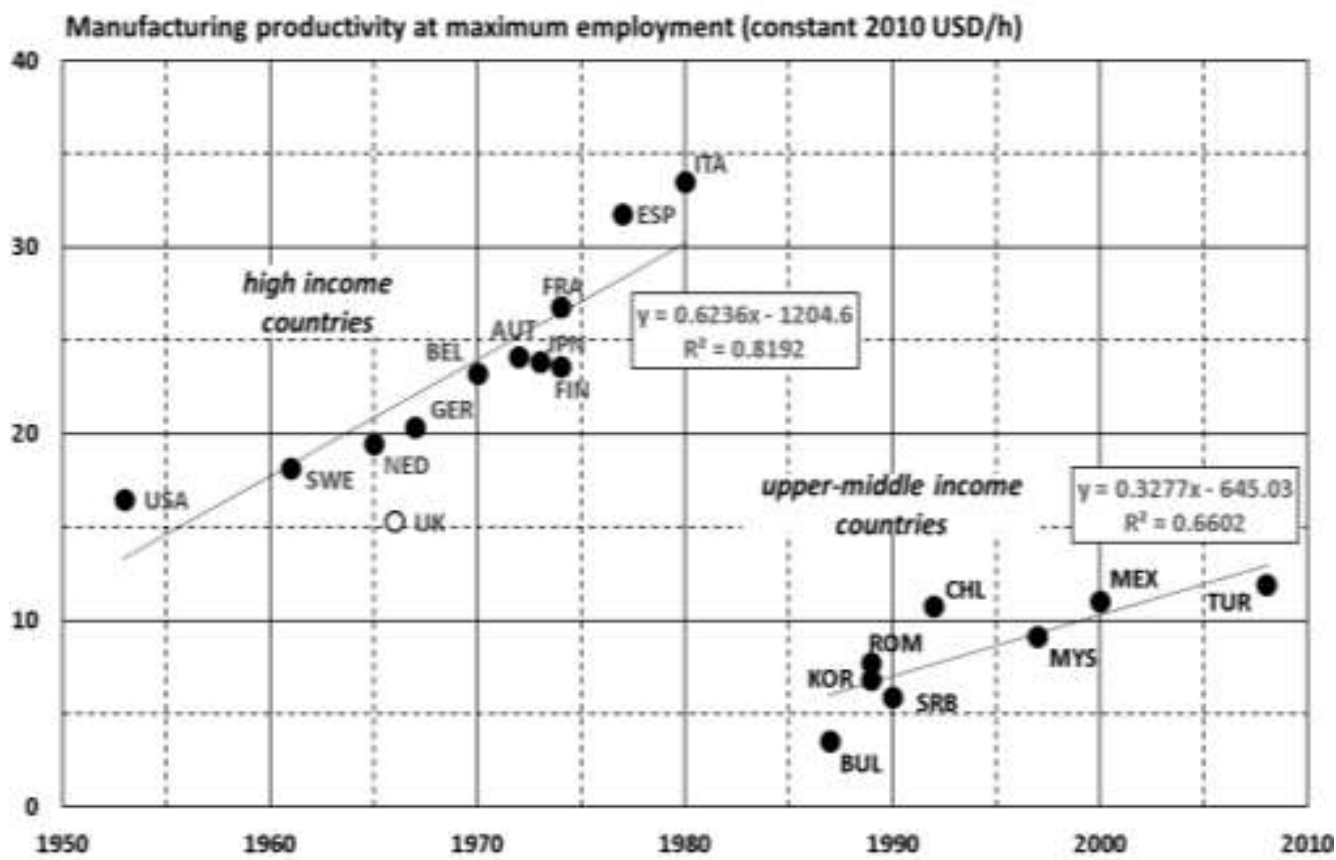

Source: Author's graph, based on ILO (2014) and World Bank (2014a) data, linear trends.

The productivity related to tipping is a rising linear function, but (again) a different one for the high-income group and the upper-middle income group. Notably, the latter function unites the former socialist and the emerging countries. Generally, the results are - given the very high $\mathrm{R}^{2}$ values - very convincing. The UK performed much below the trend line level of productivity and is thus seen as an outlier. 


\section{Discussion}

After World War II, national economies were rather confined entities with export rates lower than before World War I. The USA was by far the most powerful and wealthy economy. Over the years, the frame conditions for business changed. By the GATT/WTO rounds and voluntary cooperation like the European Union, markets became more permeable and interconnected (Meier and Roehr 2004). The new market conditions helped to raise the welfare of high-income countries to about the American level (Vernon 1979).

With the fall of the iron curtain and the opening of the East around 1990, these developments have been taken further. In the globalized economy, most markets are open and connected and more and more less-developed countries have become economically involved, taking part in the international division of labour (Abele et al. 2006). This has been driven by multi-national companies (MNCs) whose economic rationale is not the benefit of any national economy, but their own (transnational) well-being, i.e. profit. The economic power of the strongest MNCs is in the order of magnitude of national states, and so is their aspired political influence.

The mature countries tipped before the era of globalization, when internationalisation was mainly pursued on the basis of exports and largely independent production in foreign countries built up by MNCs. Division of labour along the value chain was rare.

Due to limited cross-border competition, national economies could develop independently and with more differences than in the globalized era. Under these conditions, the welfare state could blossom in many developed countries. In such a comparably little-connected environment, there was like a standard course of industrial development, but also room for national peculiarities. Due to mainly national competition, the sectoral productivity increased continuously. At a certain productivity level, further transfer of workforce into the manufacturing sector was inhibited. The sectoral output fulfilled the actual demand, so further productivity rises would rather diminish the workforce than grow the market size and in this course require more workforce. The tipping point is reached.

Since technical development becomes at least partly transferred across national borders, the tipping point of national economies is moving over time, productivity rises result in a shift over time towards higher income (x-axis) and lower relative employment (y-axis).

The outliers of the standard function of mature economies for relative manufacturing employment over GDP per capita (log) can be explained as follows:

\section{Netherlands}

The Netherlands were a case of sectoral crowding out. Investment went into the natural resource sector rather than in manufacturing after the detection of the Groningen gas field (Backhouse, 2002). 
United Kingdom

The productivity development of the UK was the elimination of competition by creating national trusts ('champions') in post-war UK Spain (Bailey et al. 2008).

Spain's economic development was very unsteady due to disruptive political changes, namely those from Franco's dictatorship to democracy and abrupt changes between socialists and conservative governments and policies. Moreover, a bubble economy funnelled by Spain's over-large construction sector (Bielsa and Duarte 2011). Spain remained the poorest country of the sample. Its national economy also suffered from high unemployment rates.

Only from the 1980s, global production networks and cross-functional cooperation evolved, driven by improved frame conditions such as reduced hindrances for trade and foreign direct investment (FDI), improved information and communication technology (ICT) and constantly falling transport costs per unit. Companies now split their value chains globally, with vendor and supplier networks controlled by worldwide supply chain management (Abele et al. 2006).

Industrial late movers cannot use the full potential that the industrial pioneers could realize in terms of employment and income. This has two main reasons:

\section{Technical progress}

Permanent process innovation constantly raises manufacturing productivity, leading to less employment needed for the same output. Thus, it is likely that national levels of manufacturing employment share will decrease over time.

Increased competition

Market pressure from globalization limits possible earnings of manufacturers.

The latter observance is in line with the product cycle hypothesis (Vernon 1979) which shows that mature production is shifted to low-cost locations over time. These countries will achieve less earnings from manufacturing than the pioneering group, even more so when multi-national firms utilize international competition to put growing pressure on their producers. In the investigated period, Western multi-national companies were able to develop and maintain a sectorspecific advantage. More simple steps of the production of investment and complex consumer goods were gradually transferred to low-cost countries which also took over the production of mass commodities.

It might be concluded that in a globalized economy, manufacturing becomes increasingly unattractive for countries - but 'beggars can't be choosers'.

For emerging countries, the productivity within reach is controlled by the external and internal demand of their goods. External demand for manufacturing goods of emerging countries is related to the willingness to pay and the bargaining power of their buyers in mature countries. Since in most cases, the offer of 
emerging countries does not involve cutting-edge but catch-up technology (East Asia) and middle positions in international supply chains (East Europe), their selling proposition is not unique and the achievable prices are rather low. As a consequence, so is the productivity and so is the national income per capita which again determines the domestic demand. Since from both buyers, external and internal, the willingness and ability to pay is low in tendency, so is the productivity that can be reached. As a consequence, lower-income countries tend to tip at lower productivity levels.

By the outlined mechanisms, a two-tier system of the maximum extension of manufacturing employment in relation to productivity has evolved. The different functions of both tipping clusters can be explained by the different level of technology produced in these groups. While the Western producers are original equipment manufacturers and technology owners, thus being able to have a high share of high-technology products in their portfolio and especially their part of international value chains, catch-up modernizers often act as sub-contractors and are not able to develop their own products. The created value is limited by the inherent technological prowess. The macro-economic two-tier system has its origin and equivalent in the micro-economic value chains where the firms of the catch-up modernization countries are mostly placed in the lower deck.

This finding is very different from the predictions of the structuralists and their successors who described a united system, a standard path of industrialization and deindustrialization.

For the late modernizers, it is hard to catch up as long as strong and wellestablished economies will defend their economic advance. The role of Mexico in comparison to the USA is a fine example to illustrate that process. Mexico could not change its role as a sub-supplier in international value chains and accordingly also stagnated in terms of national wealth. On the other hand, there are chances on the basis of close cooperation and open markets, as the largely improved living conditions in several East European countries illustrate.

The underlying analysis (Przywara 2016) has shown that catch-up modernization can be well supported by state dirigisme, as the very different examples of post-war France and lately China illustrate. To achieve technological leadership requires innovation capacities that are only released by independent thinking. This means that the state in some form has to give way to entrepreneurial spirit and activity.

Most impressive results were achieved by Korea which has fully caught up on the basis of consequent technological development, bringing its leading firms into the position of technological leadership. Korea has shown that it is possible to overcome the distance on the basis of the acquisition of technological know-how (ship-building, cars, consumer electronics, and computers).

While the findings for mature and developing countries and their two-tier system are considered as sound and well-based, it has to be underlined that each country follows its own unique path set by its geography and its societal and economic pre-requisites and finally carved by its political system and actors. Social unrest and class segregation hampers economic development as well as well-meant protection of dying industries to avoid social hardships, as especially a 
number of examples of Latin American countries have shown (see addendum below).

\section{Summary and Outlook}

Industrialization and subsequent deindustrialization in terms of a decline of the share of workers in manufacturing are natural consequences of the technical development towards automation and innovation. The course of deindustrialization is country-specific and is influenced by the respective country's position in the international division of labour.

Rowthorn (1994) predicted an inverted-U relationship of the share of manufacturing employment over income per capita $(\log )$ and calculated the tipping point at which deindustrialization starts. In this study, Rowthorn's theory was tested on a sample of 12 mature and 25 emerging countries.

Two approximately parallel falling linear functions for relative manufacturing employment over GDP per capita (log) for mature and emerging states were identified. There is a large welfare gap between both groups. It results from the international division of labour, i.e. mature country OEMs with technological ownership and innovative high-price products vs. sub-suppliers and well-known low-cost products of emerging states.

Manufacturing productivity was identified as the key driver and indicator for success of the manufacturing sector. In accordance with Rowthorn's theory, it was found that the country-specific maximum in relative employment in manufacturing is reached at a certain threshold productivity. Corresponding to the findings on peak manufacturing employment of income per capita, there are two rising linear functions of critical manufacturing productivity over time related to mature and emerging economies, respectively.

The novel theory is ready to be tested in subsequent analyses of the structural change of emerging states.

\section{Addendum: Hints for successful Industrial Policies}

By a detailed investigation of structural shifts (Przywara 2016), it became clear that economic success can be assured by different economic means, i.e. an emphasis on different industrial or service sectors, in the course of international division of labour.

Manufacturing, especially high-technology manufacturing, is one of the options to achieve economic success that several states pursued. In the investigated globalized period (1993-2008), Austria and Germany, Finland and Sweden were the most successful of these states.

Focusing on manufacturing requires a sound and specific know-how base which can be considered as a core competency. Furthermore, a continuous ambition to innovate products and processes is necessary to assure state-of-the-art products and a high productivity. Especially in the globalized economy of recent 
decades, characterized by merciless competition through open-market policies and neo-liberal politics, long-known economic success stories in manufacturing like those of Spain, Italy, France and Japan became jeopardized and their habitual policies scrutinized. Their strongly state-led policies sufficed for developing a strong manufacturing sector after World War II and being successful through the 1970 s and 1980s, but in the globalized era, these policies were apparently more and more insufficient for sectoral and overall economic success.

Productivity was identified as the key driver and indicator of success in the manufacturing sector. Industrial policies need to aim at high productivity since competition today is on a global platform. Countries not being able to keep up with the speed are running the risk of trade losses and in that turn economic shortfalls. Under these circumstances, short-term 'social' policies, i.e. those of retaining jobs instead of raising productivity, have little chances to lead to satisfactory results in the mid or long term as a number of examples from Latin America, but also Spain and France prove.

On the other hand, oversteered neo-liberal policies can lead to very critical economic situations, especially if applied dogmatically at the wrong time and the wrong place, as the example of Finland around 1990 showed impressively. Such policies do not fit well with high-tech manufacturing which depends on institutions for training and education to be ready to create the incremental innovations that assure market success. If the delicate interplay of institutions that have evolved over a long time is interrupted by harsh interventions, the comparative institutional advantage of an economy will suffer. The case of Finland is exemplary for this.

While in Western economies, a constant increase in productivity over time was the normal case, four nations stepped out of line and stagnated:

Spain, Italy (from around 1995)

France (from around 2000)

Japan (from around 2005)

In terms of productivity, the UK was lagging far behind in 1973. On the basis of merciless industrial policies, only the fittest manufacturing firms survived, so the productivity rose fast, but very high numbers of jobs became cut. The face of the British society changed by far most radically, even in relation to many former Eastern Bloc states.

The main lesson to be learned for achieving a solid macro-economy is that it is composed of many healthy and ambitious micro-economic units. This means two things:

Private micro-economic units will not be able to organize adequate institutions to assure their human resources and an efficient state administration. From high market pressure and limited resources for the individual firm, market failure will result, i.e. the privatization of public goods will not work. Examples are the education sector and also basic research which need to be organized on a broad basis which individual 
firms will not provide. To put it more poignantly: Neo-liberalism will dig its own grave if taken too far.

On the other hand, as the results of socialism, but also western dirigisme show, governments and their administrations are poor entrepreneurs. They are lacking creativity and drive to be innovative, so in a globalized economy, there is hardly a possibility for state-owned conglomerates to succeed in the top tier of global manufacturing.

While the latter is without any doubt correct for mature economies, see the failed attempt to grow 'national champions' in the UK, it has to be noted that catch-up industrialization can be and has been successfully organized by or with strong support of government in many states like France, Japan, Korea and recently in China. By state support, their infant industries could be taken over the first steps to marketability of their products.

But when reaching a certain stage of maturity, simply copying available know-how does not lead to further progress. Thus, especially late-moving states have to learn that old apodictic certainty has to be given up at a certain point if progress shall not come to a halt at that stage of development.

Industrial policies and forms of deindustrialization in emerging countries showed a very heterogeneous picture. Initially, a regional structure of analysis was pursued. Although the industrial development of nations within regions was by no means homogeneous, regional clusters of deindustrialization patterns were detected.

In East Asia, industry was built up, so the economic development was largely related to the success of the industry. Restless catch-up modernization helped to increase the national wealth of all states. Industrialization in any investigated respect (workforce, total working time, output) was the normal case.

China managed to raise its productivity by outstanding growth rates, so it could increase its industrial output without raising its number of people employed in the manufacturing sector.

High GDP p/c rises were the predominant scenario in East Asia.

The manufacturing sector in Latin America was found to be largely stagnating. Most Latin-American countries limited their deindustrialization in terms of employment by very low productivity rises or even losses. Very little increases of the average wealth per capita were the logical consequence of such efforts.

Argentina and Chile pursued a different agenda. Their comparatively tough industrial policies assured high productivity rises and improvements in the national income per capita, but also boosted the volatility of the change process.

In Venezuela, with its abundance of oil, crowding out by its primary product sector prevented the manufacturing industry from growing. Yet, since this assured that only productive investments were made, the remaining manufacturing industry was relatively efficient. 
In East Europe's EU member states, there was some very limited relative shrinking of employment in the manufacturing industry, but at rising output.

Like in East Asia, high GDP p/c rises were the predominant scenario. They were mostly achieved by becoming part of international value chains of MNCs, so the national economies turned into dependent market economies (DMEs).

The CIS and EU aspirants group shows a mixed picture. Most countries were tough modernizers which were pushing their productivity while accepting grave signs of deindustrialization. They were able to boost their national income on primary products (Russia, Kazakhstan) or services (Croatia).

The Ukraine could not keep pace with these countries. It arrived quite miserably and with an eroded industrial base.

As in all mature states, also in almost all emerging states a shift out of agriculture (with the exception of Ecuador) and into services, especially knowledge-intensive business services (with the exception of Venezuela), was observed.

Abundance in natural resources helped a number of states (Kazakhstan, Russia, Venezuela) to increase their national income but hampered their manufacturing sector because of detouring necessary investments ('Dutch disease').

Bringing know-how into an emerging country is a delicate task for the government since it requires to cooperate with MNCs. In return, they will urge for political influence. In the case of East European dependent market economies, this influence has been taken very far, but it helped to raise the living standard rapidly. The feeling of a lack of control together with mental over-burdening by the very rapid change has contributed to the recently growing success of nationalist parties, e.g. in Hungary and Poland.

State-permeated market economies (SMEs) like China are powerful enough to stay in control even of large MNCs, so they allow them to invest but at the same time try to get into possession of their technology, i.e. intellectual property, be it legally or illegally.

Leaving familiar paths is not an easy task. It is even harder to work against the deeply internalized collective memory that is subsumed under the concept of national culture. Policies need to consider the inherent values and the long-term impact of cultural coinage. National culture is of major influence on the success of the national manufacturing sector. According to the underlying study (Przywara, 2016), countries with a lower power distance, indicating less hierarchical thinking and management, were better able to increase their manufacturing productivity, i.e. the most important indicator for sectoral ambition and predicator for economic success. 


\section{References}

Abele E, Kluge J, Näher U (eds) (2006) Handbuch Globale Produktion [Handbook Global Production]. München: Hanser.

Bach HU, Riefers R (eds) (1970) Zeitreihen zur Erwerbstätigkeit [Time series on employment]. Mitteilungen aus der Arbeitsmarkt- und Berufsforschung 3(2): 107123.

Backhouse RE (2002) The Macroeconomics of Margaret Thatcher. Journal of the History of Economic Thought 24(3): 313-334.

Bailey D, Kobayashi S, MacNeill S (2008) Rover and out? Globalisation, the West Midland auto cluster, and the end of MG Rover. Policy Studies 29(3): 267-279.

Bielsa J, Duarte R (2011) Size and linkages of the Spanish construction industry: key sector or deformation of the economy? Cambridge Journal of Economics 35(2): 317334.

Bryson J, Taylor M (2008) Enterprise by 'Industrial' Design: Creativity and Competitiveness in the Birmingham (UK) Jewellery Quarter. Retrieved from https:// bit.ly/2P40V4P.

Clark C (1940) The conditions of economic progress. London: Macmillan.

Dasgupta S, Singh A (2006) Manufacturing, Services and Premature De-Industrialisation in Developing Countries: A Kaldorian Empirical Analysis. Centre for Business Research, Faculty of Economics, Cambridge: University of Cambridge.

European Commission (ed) (2014) Eurostat Database. Retrieved from https://bit.ly/le KIdTj.

Federal Reserve Bank of St. Louis (ed) (2018) FRED Database. Retrieved from https://bit.ly/2ABABGi.

Fisher A (1935) The clash of progress and security. London: Macmillan.

Fourastié J (1949) Le Grand Espoir du XXe siècle. Progrès technique, progrès économique, progrès social[ The Great Hope of the twentieth century. Technical progress, economic progress, social progress]. Paris: Presses Universitaires de France.

Fourastié J (1954) Die große Hoffnung des 20. Jahrhunderts[The great hope of the 20th century]. Köln: Bund-Verlag.

Groningen Growth and Development Centre (ed.) (2012) EU KLEMS - Growth and Productivity Accounts: Data in the ISIC Rev. 4 industry classification, rolling updates. Retrieved from https://bit.ly/2zcv874.

Henning FW (1995) Die Industrialisierung in Deutschland 1800 bis 1914 [Industrialization in Germany 1800 to 1914] (9 $9^{\text {th }}$ ed) Paderborn: Schöningh.

Hospers GJ, Steenge AE (2002) Structural and Institutional Change in Europe: An Analysis inspired by Fourastié and Perroux. In Prinz A, Steenge A, Vogel A (eds) Agglomeration, Population und Koordination in Europa. Münster: LIT Verlag, 1-34.

International Labour Organization (ILO) (ed) (2014) ILO main statistics (annual). Retrieved from https://bit.ly/1UU3uls.

Kaldor N (1966) Causes of the Slow Rate of growth in the United Kingdom. Cambridge: Cambridge University Press.

Kitson M, Michie J (2014) The Deindustrial Revolution: The Rise and Fall of UK Manufacturing, 1870-2010. In Floud R, Humphries J, Johnson $\mathrm{P}$ (eds). The Cambridge Economic History of Modern Britain Volume II. 1870 to the Present. Cambridge: Cambridge University Press, 302-329.

Klodt H (2014a) Deindustrialisierung. Retrieved from https://bit.ly/2yKbwrt.

Klodt H (2014b) Drei-Sektoren-Hypothese. Retrieved from https://bit.ly/2RkJUjq.

Klodt H (2014c) Sektoraler Strukturwandel. Retrieved from https://bit.ly/2yGGq48. 
Kollmeyer C (2009) Explaining Deindustrialization: How Affluence, Productivity Growth, and Globalization Diminish Manufacturing Employment. American Journal of Sociology 114(6): 1644-1674.

Lawson N (1985) Oral Evidence. Report from the Select Committee on Overseas Trade, HMSO, London.

Lever W (1991) Deindustrialisation and the Reality of the Post-industrial City. Urban Studies 28(6): 983-999.

Lewis WA (1954) Economic Development with Unlimited Supplies of Labour. The Manchester School of Economic and Social Studies 22: 139-191.

Maddison A (1995) Monitoring the World Economy. Paris: OECD Development Centre.

Meier H, Roehr S (eds) (2004) Einführung in das Internationale Management [Introduction to International Management]. Herne: Verlag Neue Wirtschaftsbriefe.

Murata Y (2008) Engel's law, Petty's law, and agglomeration. Journal of Development Economics 87(1): 161-177.

Palma JG (2005) Four Sources of "De-Industrialization" and a New Concept of the "Dutch Disease". In Ocampo JA (ed) Beyond Reforms - Structural Dynamics and Microeconomic Vulnerability. Palo Alto, CA and Washington, DC: Stanford University Press and The World Bank, 71-116.

Petty W (1690) Political Arithmetick. London.

Pohl HJ (1970) Kritik der Drei-Sektoren-Theorie [Criticism of the three-sector theory]. Mitteilungen aus der Arbeitsmarkt- und Berufsforschung 3(4): 313-325.

Przywara R (2016) Versions of Deindustrialization - A model-based analysis 1973-2008. $\mathrm{PhD}$ Thesis, Cheltenham: University of Gloucestershire.

Przywara R (2017) Deindustrialization - Opportunity or Threat? Athens Journal of Business and Economics. Retrieved from https://bit.ly/2QckHb7.

Rowthorn R (1994) Korea at the Cross-Roads. Working Paper 11, Cambridge University, ESRC Centre for Business Research, Cambridge.

Rowthorn R, Wells JR (1987) De-industrialization and Foreign Trade. Cambridge: Cambridge University Press.

Singh A (1977) UK Industry and the World Economy: A Case of Deindustrialization? Cambridge Journal of Economics 1(2): 113-136.

Statistika Centralbyran (ed) (1970) 1970 Statistical Abstract of Sweden. Stockholm: Kungl. Boktryckeriet P.A. Norstedt \& Söner.

United Nations (ed) (2002) International Standard Classification of All Economic Activities - Revision 3.1. New York: United Nations.

United Nations (ed) (2008) International Standard Classification of All Economic Activities - Revision 4. New York: United Nations.

Vernon R (1979) The product cycle hypothesis in a new international environment. Oxford Bulletin of Economics and Statistics 41(4): 255-267.

World Bank (ed) (2011) Changes in Country Classifications. Retrieved from https://bit.ly/ 2qkncwo.

World Bank (ed) (2014a) Data/Indicators. Retrieved from https://bit.ly/2Ohqfis.

World Bank (ed) (2014b) How does the World Bank classify countries? Retrieved from https://bit.ly/2luxClo.

Young A (1928) Increasing Returns and Economic Progress. The Economic Journal 38(152): 527-542. 


\title{
Bangladesh Trade with India: Trends and Patterns
}

\author{
By Anisul M. Islam*
}

Bangladesh has a large and persistent trade deficit with its neighboring country India over the years. This paper explored the trends and patterns of trade between these two countries using both aggregated and disaggregated data. More specifically, it examined the relative position of the two countries in global trade, explores the overall trend in exports to and imports from India, and the trend in trade balance using aggregate level data. Further, utilizing some disaggregated data, analysis is conducted regarding the commodity composition of Bangladesh exports to and imports from India by major product categories. Additionally, the paper estimates revealed comparative advantage (RCA) to reflect inter-industry trade based on comparative advantage by $H S-2$ digit commodity groups. The paper finds that India has a much stronger position in the global trade vis-à-vis Bangladesh and that India strongly dominates Bangladesh in bilateral trade, resulting in a very large and persistent trade deficit with India. At a disaggregated level, the paper finds that Bangladesh has comparative advantage in some products whereas India has comparative advantage relatively in more product categories.

Keywords: Exports, Imports, Revealed comparative advantage, Trade balance

\section{Introduction}

Bangladesh is a small emerging developing economy in South Asia whereas India is a large and dominant country in the South Asian region in terms of population, land area, other natural resource endowments, education and technology, and size of the economy compared to Bangladesh and other of its neighboring countries. India is also the second largest country in the world after China in terms of population size. In spite of being the second largest country in the world in terms of population, India still has much less population density $(0.36$ times) than Bangladesh and India has about twice (1.83 times) the level of standard of living measured by the magnitude of per capital GDP in international PPP\$ (author calculations based on world Bank 2018 data). Based on some other indicators, India and Bangladesh have strong similarity such as in terms of population growth rate (1 times), real GDP in PPP\$ growth rate (only 1.15 times), and the CPI based inflation rate ( 0.95 times) (author calculations based on world Bank 2018 data).

This paper examined the relative position of the two countries in global trade, explores the overall trend in exports to and imports from India, and the trend in trade balance using aggregate level data. Further, utilizing some disaggregated data, analysis is conducted regarding the commodity composition of Bangladesh exports to and imports from India by major product categories. Additionally, the

*Professor, University of Houston-Downtown, USA. 
paper estimates revealed comparative advantage (RCA) to reflect inter-industry trade based on comparative advantage. The paper uses data collected from various country level and international data sources. Both aggregate level and disaggregated level data were utilized in the study. The paper is of critical importance to political leaders and policy makers in both countries, including researchers, think tanks, academics, and various international organizations.

\section{Literature Review}

A brief review of literature is conducted and presented in this section. Rather and Gupta (2014) discusses the role and significance of Bangladesh-India cooperation to improve cross-border trade and investment between the two countries and emphasized that increased Indian investments in the Bangladesh economy could increase integration, generate employment and help reduce the large trade deficits of Bangladesh with India. The paper did not undertake any rigorous empirical analysis of the trade patterns between the two countries. In a different study, Islam (2011) examined the Bangladesh-India trade trends for a limited number of years and made some efforts to analyze the trade patterns between the two countries from 2005 to 2009 fiscal years. Along with the rising trade deficit problem facing Bangladesh with India, the paper also examined a number of trade barrier issues limiting trade between these two countries, particularly those that act to limit Bangladesh exports to India. The paper then focuses more on the trade potentials for Bangladesh with the North-Eastern parts of India where Bangladesh might have some comparative advantage in exporting certain products to these remote regions of India. He further argues that such trade would be highly complementary to both nations and have the potential to bring closer integration of Bangladesh with these rather isolated remote regions from the mainland India, particular the four regions of Assam, Tripura, Meghalaya and Mizoram, all bordering Bangladesh in the North-Eastern part of India located between Bangladesh and Myanmar.

Basher (2013) examines the UNCTAD data just for two years, 2001 and 2011, to analyze overall trade along with trade by some major commodity groups and finds that Bangladesh exports to India was dominated by primary products and its imports from India was also dominated by similar primary products instead of manufacturing products. The author examined several trade related indices such as revealed comparative advantage, bilateral trade intensity, trade specialization index, trade complimentary index and intra-industry trade index for those two years and found that Bangladesh and India trade is more competitive rather than complementary in nature. While this study did compute a number of trade related indices, a few of the measurement formulas were either written in a confusing manner and/or could even be inaccurate, rendering estimates and conclusion based on those estimates to be questionable. Additional studies that discussed various aspects of the trade and other economic relations between these two neighboring countries include studies by Ahmed (2006), Bammi (2010), Dutta (2010), and 
Mukherjee (2015). These studies also discussed the potentials for improving trade relations between the two countries from different perspectives.

Some of the existing empirical studies have shown that there exists a rather large and growing volume of informal (unofficial and underground) trade between the two countries. Kashyap (2014) reported that the informal exports from India to Bangladesh were about USD 4 billion, which is of about similar magnitude of the volume of formal trade. Such informal trade occurs through various border areas without official channel (smuggling) and some event through official channels but through such corrupt practices (such as under invoicing of imports with official knowledge but occurs through bribery). Additional studies that focused on this type of trade include Bakht (1994), Chaudhary (1995), IBCCI (2016), Pursell (2007), Pohit and Taneja (2000, 2003), Taneja (2001), World Bank (2015), among others. Most of these studies found existence of large volume of informal trade beyond the officially recorded trade. Additionally, Taneja (2001) found that Bangladesh has large trade deficit even in the informal trade sector beyond the rising trade deficit of the country in the official (formal) trade sector. Pursell (2007) also examined Bangladesh-India trade focusing on illegal trade between the two countries, especially in the context of Sugar industry trade. Using data from 1994 to 2005 for this industry, he used simulations to examine the implication of any possible free trade agreement on sugar trade between these two countries and came out with some policy recommendations. IBCCI (2016) mentions that the size of the informal trade could be as large as the formal trade and the direction of this trade being mostly dominated by trade flowing from India to Bangladesh, but not the other way around. As such, it can be argued that Bangladesh may have sizeable trade deficit with India in the area of informal trade as well.

Using product-specific disaggregated data, Basu and Datta (2007a) studied Bangladesh-India trade deficits and tried to find the causes of persistent deficits facing Bangladesh in its trade with India. In this effort, they estimated revealed comparative advantage (RCA) and cosine measures to examine trade similarity and trade complementarity between the two countries and found that Bangladesh and India trades in very similar products and has little trade complementarity. Using data for 1990 to 1998, they estimated RCA values at three-digit SITC classification level indicated that both India and Bangladesh has comparative advantage in unskilled labor-intensive goods and hence their exports become competitive rather than complementary in the global markets, not a surprising result due to the fact that both countries are low-wage labor-abundant countries. However, they also found that India has much higher RCA values than Bangladesh in many more product categories while Bangladesh has RCA values greater than India in only a small number of product categories, which poses Bangladesh in a greater disadvantage in its exports to India compared to the other way trade.

Going beyond the RCA measures, Basu and Datta (2007a) estimated the Cosine measure of export-export similarity and export-import complementarities between the two countries. These estimates also clearly showed much stronger advantages for India against Bangladesh in their mutual trade prospects in each other's markets. Another paper that used product-specific disaggregated data was 
by Alam, Uddin, Alam and Malakar (2009). They examined comparative advantage of Bangladesh vis-à-vis India and found that India has advantage in a variety of product categories whereas Bangladesh has such advantage in a limited number of product categories. Another study that used disaggregated data to examine composition and patterns of trade include Khan, Islam, Ashiqun, and Paul (2010) and found stronger advantage for India against Bangladesh.

Given that the two countries are close neighbors and given their strong political and diplomatic ties, the prospects for bilateral free trade agreements between Bangladesh and India were examined and their implications for both countries analyzed by several studies (Bhardwaj 2014, Bhuyan 2006, IBCCI 2016, Pursell and Sattar 2006, Razzaque and Basnett 2014, World Bank 2006, among others). These studies also examined the implications of a free trade agreement on the two countries trade and their respective trade balance positions.

Some other studies exist related to Bangladesh-India trade. However, most of these studies focus on the impact of exchange rate on trade imbalance between these two countries and found that Bangladesh has a large trade deficit with India and the volume of that deficit has been increasing over time (Akhtar and Salim 1999, Basu and Datta 2007a, Basu and Datta 2007b, Islam et al. 2013, Rahman 2005, among others). Basu and Datta (2007b) focused on and estimated bilateral overall trade deficits of Bangladesh with India and used aggregated annual timeseries data from 1974 to 2001 and co-integration analysis to estimate the export and import functions along with a trade balance function to examine the effects of misaligned exchange rate of Bangladeshi Taka against Indian Rupees in explaining the persistent trade deficits. In doing so, the authors tried to draw some parallel from Indonesian experience and suggested that Bangladeshi policy makers may want to draw some lessons from that country's experience in devising its own exchange rate policy. However, most of these studies are quite dated and utilizes time series data with small sample sizes, resulting in biased and unreliable parameter estimates. Further, some others do not utilize sophisticated statistical and econometric methodologies and techniques. Since these studies are not directly relevant for the purpose of this paper, further critical elaboration on these studies was not provided here.

\section{Methodology: Measurement of Trade Indicators and Data Sources}

We have utilized a number of trade related measurements and indicators in this study. The trade related measurements used in this paper are listed below with their respective formula with equation numbers on the L.H.S. are given as follows:

\section{Measurement of Trade Indicators}

Generally, the degree of trade globalization is measured by country exports, country imports or country overall trade (exports plus imports), each as \% of country GDP. However, following the WTO, this paper uses the following 
measure of the degree of trade globalization based on average of exports and imports as given in equation (1) below:

1. Degree of Country Trade Globalization (or Integration) $=$ Average Trade as $\%$ of GDP $=\{($ Country Exports + Country Imports $) / 2\} * 100 /$ GDP

The paper proposes to measure the relative significance of a country's trade in relation to global trade and uses separate measures for goods (merchandise) exports, commercial service exports, goods imports, and commercial service imports given by the following four equations (2) through (5) given below:

2. Country Goods Exports as \% of World Goods Exports $=($ Country Goods Exports*100)/World Goods Exports

3. Country Goods Imports as $\%$ of World Goods Imports $=($ Country Goods Imports*100)/World Goods Imports

4. Country Service Exports as \% of World Service Exports $=$ (Country Service Exports*100)/World Service Exports

5. Country Service Imports as $\%$ of World Service Imports $=($ Country Service Imports*100)/World Service Imports

Going beyond a country's position in the global context, we will use some trade measures to indicate the bilateral trade between the two countries under study, Bangladesh and India. Several measures are proposed here which are related to bilateral aggregate trade given by the following four equations (6) through (9) given below:

6. Country Overall or Aggregate Trade $(\mathrm{T})=($ Country Exports + Country Imports $)=(\mathrm{X}+\mathrm{M})$

7. Country Exports as \% of Country Total Trade $(\mathrm{T})=($ Country Exports $(\mathrm{X})$ *100)/Total Trade (T)

8. Country Overall Trade Balance $(\mathrm{TB})=($ Country Exports - Country Imports $)=(\mathrm{X}-\mathrm{M})$

Annual average growth rate of aggregate trade variable $(\mathrm{T})$ between the beginning and the ending year in the sample time-series data:

9. Annual Average Growth Rate of $\mathrm{T}=\left[\left\{(\mathrm{Tt}-\mathrm{Tt}-\mathrm{k})^{*} 100 / \mathrm{Tt}-\mathrm{k}\right\} /(\mathrm{k}-1)\right]$, where $\mathrm{k}$ is the number of year in the sample 
For measuring Bangladesh's country specific export and import shares, the following equations were used to measure such country-specific market shares given in equations (10) and (11) below:

10. Bangladesh Country-specific export shares $=$ (Bangladesh exports to country $\mathrm{j} * 100)$ / Bangladesh total exports to the world

11. Bangladesh Country-specific import shares $=($ Bangladesh imports from country $\mathrm{j} * 100$ ) / Bangladesh total imports from the world

For product-specific disaggregated data analysis for trade and trade balance, we propose several measures and indicators given by the following equations (10) through (12) below:

12. Share of Top Export of Product $i$ to India as \% of Total Bangladesh Exports to India $=(X i$ to India*100/X to India, $\quad$ where $\mathrm{i}=1,2, . ., 9$ top export products.

13. Share of Top Imports Product i from India as \% of Total Bangladesh Imports from India $=($ Mi from India $* 100 / M$ from India, $\quad$ where $\mathrm{i}=1$, $2, . ., 10$ top import products.

14. Total Trade with India in Product $\mathrm{i}(\mathrm{Ti})=(\mathrm{Xi}+\mathrm{Mi})$, where $\mathrm{i}=1,2, \ldots, \mathrm{n}$ product categories.

15. Trade Balance with India for Product $\mathrm{i}(\mathrm{TBi})=(\mathrm{Xi}-\mathrm{Mi})$, where $\mathrm{i}=1,2, .$. $\mathrm{n}$ product categories.

Trade in different product categories can be classifies as inter-industry trade versus intra-industry trade. The former is the traditional trade which happens between two different product categories (a country exporting one product and importing a different product) based on comparative advantage (or disadvantage). The latter is the non-traditional intra-industry trade (a country exporting and importing within the same product category), which is based on product differentiation and economies of scale (Grubel-Lloyd 1975). This paper did not pursue the latter category of trade; rather it focuses on the former comparative advantage based inter-industry trade as elaborated further below.

The former type of trade and the issue of specialization based on comparative advantage are discussed extensively in the international trade literature. However, measuring comparative advantage at the product level is not that easy as such measures would requires a lot of data at the industry or product level such as product-specific export and import data as well as product-specific input productivity or input cost data. However, Belassa (1965) proposed a simpler measure which uses ex post trade data alone that would reveal comparative advantage or disadvantage in a given product i. A variant of this approach can be calculated by a formula as given in equation (16) as follows: 
16. Revealed Comparative Advantage for product i $(\mathrm{RCAi})=\{(\mathrm{Xi}-$ $\mathrm{Mi}) /(\mathrm{Xi}+\mathrm{Mi})\}$,

where $\mathrm{i}=1,2, . ., \mathrm{n}$ product categories.

A positive value of RCAi index would indicate revealed comparative advantage in that product for that country and a negative value would indicate revealed comparative disadvantage.

\section{Data Sources}

To measure the above mentioned trade related indicators, data were collected from various country specific national sources (both Bangladesh and India) and international sources which are publicly available. The national sources include Dhaka Chamber of Commerce and Industry (DCCI 2016), and India-Bangladesh Chamber of Commerce and Industry (IBCCI 2016). The international data sources include the WTO (2018), The World Bank (2018), Globaledge (2018) data from Michigan State University, among others. Both time-series data from 2009-2016 and cross-section data by major product categories for 2015 were collected and analyzed in the paper.

\section{Empirical Findings}

The empirical results are presented in this section. This section is subdivided into several sub-sections, each with its own sub-headings. Each country's trade performance in the context of global trade is given by equations (1), (2), (3), (4) and (5). The calculated values of these indicators are presented in Table 1 below.

\section{Bangladesh and India Trade Position in the Global Context: Performance Comparison}

This sub-section focuses on the comparative trade performance of Bangladesh and India in the context of global trade. The trade-GDP ratio (\%) is generally measured as total trade (Exports + Imports) as \% of country GDP to indicate a country's degree of trade openness and trade integration with the world. However, following the WTO's country trade profile reporting, the average of a country's exports to the word and imports from the world as \% of country GDP is used to measure trade openness and integration. Using this average-based measure as given in equation (1) above, the relative performance of Bangladesh is not too different than that of India as both countries' percentages are in the $22-24 \%$ range as reported in Table 1 with India having a slightly higher percentage value. Thus it can be argued that the degree of trade openness and integration of both countries with the rest of the world are very similar. 
Table 1. Bangladesh and India Global Trade Performance Comparison: 2015

\begin{tabular}{|l|c|c|c|}
\hline $\begin{array}{l}\text { Trade Performance Indicators in the } \\
\text { Global Context }\end{array}$ & India & Bangladesh & $\begin{array}{c}\text { India-Bangladesh } \\
\text { Comparison }\end{array}$ \\
\hline $\begin{array}{l}\text { Average Trade as (\%) of country } \\
\text { GDP }\end{array}$ & 24.8 & 22.4 & Similar \\
\hline $\begin{array}{l}\text { Goods Exports as \% of World Goods } \\
\text { Exports }\end{array}$ & 1.62 & 0.20 & India stronger \\
\hline Goods Exports World Rank & 19 & 60 & India stronger \\
\hline $\begin{array}{l}\text { Goods Imports \% of World Goods } \\
\text { Imports }\end{array}$ & 2.34 & 0.24 & India stronger \\
\hline Goods Imports World Rank & 13 & 54 & India Stronger \\
\hline $\begin{array}{l}\text { Service Exports as \% of World } \\
\text { Service Exports }\end{array}$ & 3.27 & 0.04 & India stronger \\
\hline Service Exports World Rank & 8 & 109 & India stronger \\
\hline $\begin{array}{l}\text { Service Imports as \% of World } \\
\text { Service Imports }\end{array}$ & 2.65 & 0.19 & India stronger \\
\hline Service Imports World Rank & 10 & 63 & India stronger \\
\hline
\end{tabular}

Sources: WTO (2016) www.WTO.org and author compilation.

However, if we estimate some other indicators separately for goods (merchandise) and commercial services using indicators given in equations (2), (3), (4), and (5), India has a much stronger trade position and performance in the global stage than Bangladesh in terms of all these indicators as shown in Table 1. Focusing on merchandise trade, India's share of world goods exports is $1.62 \%$ compared to Bangladesh's share of only $0.20 \%$ and with India's rank in the world being 19 compared to Bangladesh's rank at 60. In terms of commercial service exports, India's global share is even better at $3.27 \%$ of world commercial service exports compared to Bangladesh's share of only $0.04 \%$ and with India's world ranking of 8 (among top 10 in the world) compared to Bangladesh's world ranking of 109. Thus, in terms of export performance, India strongly outperforms Bangladesh in the global stage in both goods exports and commercial service exports in recent years (2015).

A similar picture arises in terms of the relative performance of imports as reported in Table 1. India's share of world goods imports is $2.34 \%$ compared to Bangladesh's share of only $0.24 \%$ and with India's rank in the world being 13 compared to Bangladesh's rank at 54. In terms of commercial service imports, India's global share is even better at $2.65 \%$ of world commercial service exports compared to Bangladesh's share of only $0.19 \%$ and with India's world ranking of 10 (among top 10 in the world) compared to Bangladesh's world ranking of 63. Thus, in terms of import performance, India again strongly outperforms Bangladesh in the global stage in both goods imports and commercial service imports. 
Bangladesh's Top Export and Import Partners in the World and Global Market Shares

This sub-section focuses on the top export partners and top import partners of Bangladesh and the respective market shares as reported in Table 2 and Table 3 below. The country-specific market shares are calculated based on equations (10) and (11) given earlier. Table 2 reports information about Bangladesh's top ten export partners with respective market (trade) shares for each of the countries. In 2015-16, the total exports from Bangladesh to the rest of the world was 41,222 million USD, of which the top ten countries constituted about $75 \%$ of the country's exports. Of the top ten, the U.S. was the largest market, taking in about $21 \%$ of total exports from Bangladesh followed by Germany with $15.56 \%$ and then the U.K. with $9.49 \%$. Thus, the U.S., Germany and the U.K. are the top three export markets for Bangladesh. It is significant to note here that India does not come within the top export partners of Bangladesh in spite of being the closest and a large and powerful neighboring country.

Table 2. Bangladesh's Top 10 Export Partners and Market Share (\%): 2015-16

\begin{tabular}{|l|c|c|}
\hline \multicolumn{1}{|c|}{ Partner Country } & Exports (million US\$) & $\begin{array}{c}\text { Market Share } \\
\text { (\% of Total Exports) }\end{array}$ \\
\hline United States & 5,107 & 21.01 \\
\hline Germany & 3,782 & 15.56 \\
\hline United Kingdom & 2,306 & 9.49 \\
\hline France & 1,560 & 6.42 \\
\hline Spain & 1,073 & 4.41 \\
\hline Canada & 1,024 & 4.21 \\
\hline Italy & 990 & 4.07 \\
\hline Netherlands & 836 & 3.44 \\
\hline Belgium & 794 & 3.27 \\
\hline Turkey & 655 & 2.7 \\
\hline Total Top Ten & $\mathbf{1 8 , 1 2 9}$ & $\mathbf{7 4 . 5 4}$ \\
\hline Total-Other Countries & 6,184 & 25.44 \\
\hline Total Exports & $\mathbf{2 4 , 3 1 3}$ & $\mathbf{1 0 0 . 0 0}$ \\
\hline
\end{tabular}

Sources: The WTO (2016), the World Bank (2016) and author calculations.

Table 3 provides estimates about Bangladesh's top ten import partners with respective market shares attributable to these countries. In 2015-16, the total imports of Bangladesh from the rest of the world were 41,222 million USD, of which the top ten countries accounted for about $69.31 \%$ of total imports with the remaining $31 \%$ from many other countries in the rest of the world. Of the top ten import partners, Thailand topped the list with $22.78 \%$ of total imports followed by India as the second largest import source with $11.23 \%$ of all imports, and China capturing the third position with about $8.76 \%$ of imports coming to Bangladesh. It seems clear that Bangladesh serves as a significant market for India's exports but India does not take in any significant amount of exports from Bangladesh. The trade relationship between India and Bangladesh thus seem quite asymmetrical 
with India having the stronger and more dominant position vis-a-vis its trade with Bangladesh.

Table 3. Bangladesh's Top 10 Import Partners and Market Share (\%): 2015-16

\begin{tabular}{|c|c|c|}
\hline Partner Country & Imports (million US\$) & $\begin{array}{c}\text { Market Share } \\
\text { \% of Total Imports) }\end{array}$ \\
\hline Thailand & 9,389 & 22.78 \\
\hline India & 4,631 & 11.23 \\
\hline China & 3,610 & 8.76 \\
\hline Indonesia & 2,462 & 5.97 \\
\hline Singapore & 2,127 & 5.16 \\
\hline Malaysia & 1,867 & 4.53 \\
\hline Brazil & 1,302 & 3.16 \\
\hline United States & 1,250 & 3.03 \\
\hline Japan & 970 & 2.35 \\
\hline Pakistan & 963 & 2.34 \\
\hline Total-Top Ten & $\mathbf{2 8 , 5 7 2}$ & $\mathbf{6 9 . 3 1}$ \\
\hline Other Countries & 12,650 & 30.69 \\
\hline Total Imports & $\mathbf{4 1 , 2 2 2}$ & $\mathbf{1 0 0 . 0 0}$ \\
\hline
\end{tabular}

Sources: The WTO (2016), the World Bank (2016) and author calculations.

\section{Bangladesh-India Trade: Analysis by Bilateral Aggregate Trade}

In this section, Bangladesh-India bilateral trade is analyzed on the basis of overall or aggregate trade. In particular, we will analyze growth and trend in exports, imports, total trade (exports plus imports) and their growth rate, exports as $\%$ of total trade, trade balance and its growth, among others. The analysis is carried out over recent years over the period of 2009-10 to 2015-16. The calculations are reported in Table 4 utilizing formulas given by equations (6) through (9) presented earlier.

In continuation of the asymmetrical trading relationship between the two countries and India's dominant position as discussed in the previous section, that situation is further reflected and reinforced in the inter-temporal trend in Bangladesh's exports to and imports from India along with the trend in exports $(\mathrm{X})$, imports (M) and total trade (T) (equation (6)), exports as \% of total trade (equation (7)), trade balance (TB) with India (equation (8)) and average annual trade growth (equation (9)). Table 4 reports the relevant time trend of these variables from 2009-10 to 2015-16 to provide evidences in these bilateral aggregate trade indicators. Columns 2, 3 and 4 of this table gives annual data of Bangladesh's exports to India, imports from India and total trade (exports plus imports) with India, and column 5 reports exports as \% of total trade.

Data reported in Table 4, columns 2, 3, and 4 show further that the total exports to India, imports from India and the total trade between them has been increasing steadily over time from 2009 to 2016. In terms of annual average growth rate over the sample period, the exports from the country has been growing at a slightly higher annual average rate of $37.73 \%$ compared to the annual average import growth rate of $28.38 \%$ with the total trade growing at an annual average 
rate of $29.19 \%$ as shown in the last row of Table 4 . The above result of exports growing faster than imports in recent years could be considered as a good and hopeful sign from the perspective of Bangladesh for possible reduction in the prevailing large deficits with India with the passage of time as discussed further below.

However, the estimates reported in column 5 of Table 4 related to Bangladesh exports to India as \% of Bangladesh total trade with India represents a rather poor export performance of Bangladesh with its trade with India. Bangladesh exports constitute only a small percentage, varying around just $10 \%$ of total trade with India as shown on column 5. This clearly indicates a disturbing picture from Bangladesh perspective in that Bangladesh trade with India is highly dominated by Bangladesh's imports from India (alternatively India's exports to Bangladesh dominates Bangladesh-India trade) to the tune of about $89 \%$ of total trade between them.

This asymmetric trading relation has resulted in a large and persistent trade deficit for Bangladesh as reported in col. 6 of Table 4 for 2015-16 in its formal trade. The last column of this table shows that Bangladesh has had a trade deficit over each year during this period and that the magnitude of the deficit seems to be quite large and persistent with no sign of any significant reduction. For example, in 2015-16, the total trade deficit was about 4,763.28 million USD compared to the deficit of 2,897.48 million in 2009-10. Hence the deficits are large and persistent indeed from the perspective of Bangladesh. In addition, over the seven year period from 2009-10 to 2015-16, the deficit has grown by $164.39 \%$ which translates into an annual average growth rate of $27.40 \%$ in the growth of deficits.

Table 4. Bangladesh-India Trade, Trade Balance and Trade Growth: 2009 -2016

\begin{tabular}{|c|c|c|c|c|c|}
\hline Year & $\begin{array}{c}\text { Exports } \\
(\mathrm{X}) \\
\text { (m. US\$) }\end{array}$ & $\begin{array}{c}\text { Imports (M) } \\
(\mathrm{m} . \text { US\$) }\end{array}$ & $\begin{array}{c}\text { Trade }= \\
(\mathbf{X}+\mathbf{M}) \\
(\mathrm{m} . \mathrm{US} \$)\end{array}$ & $\begin{array}{c}\text { Exports as } \\
\% \text { of } \\
\text { Trade }\end{array}$ & $\begin{array}{c}\text { Trade } \\
\text { Balance } \\
(\mathbf{T B}) \\
=(\mathbf{X}-\mathbf{M}) \\
(\mathrm{m} . \mathrm{US} \$)\end{array}$ \\
\hline $2009-10$ & 304.62 & 3202.1 & 3506.72 & 8.69 & -2897.48 \\
\hline 2010-11 & 512.5 & 4560.01 & 5072.51 & 10.10 & -4047.51 \\
\hline $2011-12$ & 490.42 & 4758.89 & 5249.31 & 9.34 & -4268.47 \\
\hline $2012-13$ & 563.96 & 4776.9 & 5340.86 & 10.56 & -4212.94 \\
\hline 2013-14 & 456.63 & 6035.51 & 6492.14 & 7.03 & -5578.88 \\
\hline $2014-15$ & 527.16 & 5828.1 & 6355.26 & 8.29 & -5300.94 \\
\hline $2015-16$ & 689.62 & 5452.9 & 6142.52 & 11.23 & -4763.28 \\
\hline $\begin{array}{l}\text { Growth } \\
\text { Rate }(\%) \text { : } \\
2009-10 \text { to } \\
2015-16\end{array}$ & 226.39 & $\begin{array}{c}170.29 \\
\text { (182.01 at } \\
\text { peak year) }\end{array}$ & 175.16 & NA & 164.39 \\
\hline $\begin{array}{l}\text { Annual } \\
\text { average } \\
\text { Growth } \\
\text { Rate }(\%)\end{array}$ & 37.73 & $\begin{array}{c}28.38 \\
(30.33 \text { at } \\
\text { peak year })\end{array}$ & 29.19 & NA & 27.40 \\
\hline
\end{tabular}

Sources: DCCI (2016)-Dhaka Chamber of Commerce and Industries, Dhaka, Bangladesh and author calculations 
As reported in other studies related to informal trade (Bhardwaj 2014), Bangladesh has additional large trade deficit of similar magnitude (estimated around additional USD 4000 million) in its informal trade with India. As such, the combined formal and informal trade deficit is really large and clearly unsustainable from Bangladesh perspective. As such, even a larger annual average growth rate of exports to India (37.73\%) compared to annual average import growth $(28.38 \%)$ as reported in the last row of Table 4 but from a smaller export base for Bangladesh and with a very small share of Bangladesh exports to India to its total trade with that country could not have any significant deficit reduction impact. The asymmetrical trade relationship against Bangladesh (in favor of India) resulting in a big and persistent trade deficit for Bangladesh is clearly not sustainable on a long-run basis and hence is of major concerns among for academics, policy makers, political leaders and people at large in Bangladesh. Given the above, it seems clear that it may take many years to reduce the deficits to more sustainable level.

\section{Bangladesh-India Trade: Disaggregated Analysis by Major Product Categories}

To gain further insights into the asymmetric trade situation of Bangladesh visà-vis India, this section focuses on disaggregated analysis of current trade and trade patterns by major commodity or product categories, particularly the top nine/ten products traded between the two countries. The respective market share of top export products from Bangladesh to India as \% of total Bangladesh exports to India is calculated using equation (12) while that of top import product share was calculated using equation (13) given earlier.

Table 5. Bangladesh's Top 9 Export Goods to India and Share (\%):2015-16

\begin{tabular}{|l|c|c|}
\hline Products & Exports (million US\$) & \% of Total Exports \\
\hline Jute Goods & 164.06 & 23.79 \\
\hline Woven Garments & 102.17 & 14.82 \\
\hline Raw Jute & 96.69 & 14.02 \\
\hline Agricultural Products & 82.00 & 11.89 \\
\hline Knitwear & 34.25 & 4.97 \\
\hline Leather \& Leather Products & 19.88 & 2.88 \\
\hline Home Textile & 14.66 & 2.13 \\
\hline Footwear & 12.48 & 1.81 \\
\hline Bicycle & 7.39 & 1.07 \\
\hline Total Top 9 Export Goods & $\mathbf{5 4 0 . 2 5}$ & $\mathbf{7 8 . 3 4}$ \\
\hline Others & $\mathbf{1 4 9 . 3 7}$ & 21.66 \\
\hline Total Exports & $\mathbf{6 8 9 . 6 2}$ & $\mathbf{1 0 0 . 0 1}$ \\
\hline
\end{tabular}

Sources: DCCI (2016)-Dhaka Chamber of Commerce \& Industries, Dhaka, Bangladesh and author calculations.

Table 5 shows Bangladesh's top nine export products to India along with the estimated percentage share of each of the ten products as \% of total exports to India for 2015-16, the most recent year for which data could be obtained. This table shows that manufactured Jute goods is the largest export earner $(23.79 \%)$ 
followed by woven garments $(14.82 \%)$ and raw jute $(14.02 \%)$ respectively in the second and third position. Bangladesh also exports some agricultural products $(11.89 \%)$ and some other items such as knitwear, leather and leather products and home textiles. The top 9 products constitute about $78.34 \%$ of Bangladesh total exports of 689.62 million USD with the remaining other products capturing about $21.66 \%$ of total exports to India.

In contrast, Table 6 shows Bangladesh's top ten import products from India along with the estimated share of each of the ten products as \% of total imports from India for 2015-16, the most recent year for which data could be obtained. This table shows that cotton (all types) constitute the largest import item with a share of $26.92 \%$ followed by vehicles $(9.36 \%)$, nuclear related materials $(7.71 \%)$, and cereals $(5.31 \%)$ respectively in the second, third and fourth position. The top 10 products constitute about $70.44 \%$ of Bangladesh total imports of 5452.90 million USD with the remaining other products capturing about $29.56 \%$ of total imports from India.

Table 6. Bangladesh's Top 10 Import Goods from India and Share (\%): 2015-16

\begin{tabular}{|l|c|c|}
\hline Products & $\begin{array}{c}\text { Import s } \\
\text { (million } \\
\text { US\$) }\end{array}$ & $\begin{array}{c}\% \text { of } \\
\text { Total } \\
\text { Imports }\end{array}$ \\
\hline Cotton (all types), cotton yarn / thread and cotton fabrics & 1468.01 & 26.92 \\
\hline $\begin{array}{l}\text { Vehicles other than railway or tramway rolling- stock and } \\
\text { parts and accessories }\end{array}$ & 510.31 & 9.36 \\
\hline $\begin{array}{l}\text { Nuclear reactor, boilers, machinery and mechanical } \\
\text { appliances, parts thereof }\end{array}$ & 420.31 & 7.71 \\
\hline Cereals & 289.12 & 5.31 \\
\hline Edible vegetables and certain roots and tubers & 260.81 & 4.78 \\
\hline Iron and steel & 236.41 & 4.34 \\
\hline Organic chemicals & 174.92 & 3.21 \\
\hline $\begin{array}{l}\text { Electrical machinery and equipment and parts thereof, sound } \\
\text { recorders and reproducers, television image and sound } \\
\text { recorders and reproducers and parts and accessories of such } \\
\text { articles }\end{array}$ & & \\
\hline Plastics and articles thereof & 171.32 & 3.14 \\
\hline $\begin{array}{l}\text { Tanning or dyeing extracts, tannins and their derivatives, } \\
\text { dyes, pigments and other coloring matter, paints and } \\
\text { varnishes, putty and other mastics, inks }\end{array}$ & 158.01 & 2.91 \\
\hline Total Top Ten Import Goods & 149.91 & 2.76 \\
\hline Others & $\mathbf{3 8 4 1 . 0 2}$ & $\mathbf{7 0 . 4 4}$ \\
\hline Total Imports & 1611.88 & 29.56 \\
\hline Soures: DCCI & $\mathbf{5 4 5 2 . 9 0}$ & $\mathbf{1 0 0 . 0 1}$ \\
\hline
\end{tabular}

Sources: DCCI (2016)-Dhaka Chamber of Commerce and Industries and author calculations.

Table 7 provides disaggregated data of exports and imports by 18 HS 2-digit major product categories. Estimated product specific total trade (Ti) for these products are reported in col. 6 for each product category using equation (14) and trade balance (TBi) for each product category is reported in col. 5 using equation (15). Column 5 shows that Bangladesh had trade surplus (+) for 8 out of 18 product categories with trade deficit in the remaining 10 categories. 
Table 7. Trade, Trade Balance and RCA by HS 2-digit Major Product Categories, 2015-16

\begin{tabular}{|c|c|c|c|c|c|c|c|}
\hline HS & Product & Exports (Xi) & Imports (Mi) & $\mathrm{TBi}=(\mathrm{Xi}-\mathrm{Mi})$ & $(\mathrm{Xi}+\mathrm{Mi})$ & $\begin{array}{c}\text { RCAi: } \\
\text { (Xi-Mi) } \\
\text { /(Xi+Mi) }\end{array}$ & $\begin{array}{c}\text { Adv (+) } \\
\text { DisAdv (-) } \\
\text { Neutral (0) }\end{array}$ \\
\hline Code & Category & (US\$) & US\$) & (US\$) & (US\$) & Ratio & Comment \\
\hline 03 & Seafood & $636,458,207$ & 0 & $636,458,207$ & $636,458,207$ & +1.00 & Adv \\
\hline 10 & Cereals & 0 & $1,837,969,824$ & $-1,837,969,824$ & $1,837,969,824$ & -1.00 & DisAdv \\
\hline 15 & Fats and Oils & 0 & $3,551,898,136$ & $-3,551,898,136$ & $3,551,898,136$ & -1.00 & DisAdv \\
\hline 27 & $\begin{array}{c}\text { Oil and Mineral } \\
\text { Fuels }\end{array}$ & $280,088,410$ & $3,126,389,886$ & $-2,846,301,476$ & $3,406,478,296$ & -0.84 & DisAdv \\
\hline 31 & Fertilizers & 0 & $1,983,289,320$ & $-1,983,289,320$ & $1,983,289,320$ & -1.00 & DisAdv \\
\hline 39 & Plastics & 0 & $1,302,968,206$ & $-1,302,968,206$ & $1,302,968,206$ & -1.00 & DisAdv \\
\hline 41 & $\begin{array}{l}\text { Hides and } \\
\text { Leather }\end{array}$ & $323,758,964$ & 0 & $323,758,964$ & $323,758,964$ & +1.00 & Adv \\
\hline 52 & Cotton & $123,674,252$ & $6,692,856,498$ & $-6,569,182,246$ & $6,816,530,750$ & -0.96 & DisAdv \\
\hline 53 & Natural Fibers & $822,979,223$ & 0 & $822,979,223$ & $822,979,223$ & +1.00 & Adv \\
\hline 58 & $\begin{array}{c}\text { Lace and } \\
\text { Tapestries }\end{array}$ & $107,017,617$ & 0 & $107,017,617$ & $107,017,617$ & +1.00 & Adv \\
\hline 61 & Apparel ; Knit & $9,936,304,901$ & 0 & $9,936,304,901$ & $9,936,304,901$ & +1.00 & Adv \\
\hline 62 & $\begin{array}{c}\text { Apparel ; Non- } \\
\text { knit } \\
\end{array}$ & $9,225,733,521$ & 0 & $9,225,733,521$ & $9,225,733,521$ & +1.00 & Adv \\
\hline 63 & Textile Articles & $1,073,491,458$ & 0 & $1,073,491,458$ & $1,073,491,458$ & +1.00 & Adv \\
\hline 64 & Footwear & $345,642,613$ & 0 & $345,642,613$ & $345,642,613$ & +1.00 & Adv \\
\hline 72 & Iron and Steel & 0 & $1,800,284,144$ & $-1,800,284,144$ & $1,800,284,144$ & -1.00 & DisAdv \\
\hline 84 & $\begin{array}{l}\text { Industrial } \\
\text { Machinery }\end{array}$ & 0 & $3,894,441,294$ & $-3,894,441,294$ & $3,894,441,294$ & -1.00 & DisAdv \\
\hline 85 & $\begin{array}{c}\text { Electrical } \\
\text { Machinery }\end{array}$ & 0 & $2,773,027,524$ & $-2,773,027,524$ & $2,773,027,524$ & -1.00 & DisAdv \\
\hline 89 & Ships and Boats & 0 & $1,317,728,008$ & $-1,317,728,008$ & $1,317,728,008$ & -1.00 & DisAdv \\
\hline
\end{tabular}


Further, as estimates in Table 7 shows, we have calculated the Balassa type (Balassa 1965; Islam, Nuwal and Nguyen 2011; and Islam and Dong 2011) Revealed Comparative Advantage RCAi index using equation (16) and the steps in calculation are shown and reported in the last four columns of this table. Mirroring the trade deficit result, there is positive RCAi indicating revealed comparative advantage for 8 products ( $44 \%$ of the listed products) and negative RCAi (revealed comparative disadvantage) for the remaining 10 product categories (56\% of the listed products). As such, Bangladesh seems to have revealed comparative advantage in products such as seafood, hides and leather, natural fiber, lace and tapestries, knit and non-knit apparel, textile articles, and footwear. The list of products with comparative disadvantage are found in cereals, fats and oils, oils and mineral fuels, fertilizers, plastics, cotton, iron and steel, industrial and electrical machineries and ships and boats.

\section{Conclusions and Further Discussions}

The empirical findings of the paper can be summarized as follows: (1) Due to its advantage over resource endowments better resource varieties, higher education and skill level of labor force, better technology, better institutions and infrastructure, bigger internal market with greater size of the economy, India is found to dominate Bangladesh in the context of global trade and global markets. (2) However, at the same time, given some similarity in resource endowments with both countries having abundant low-wage labor supply, both countries seem to have comparative advantage in similar labor-intensive products, both countries seems to have greater degree of trade competitiveness than trade complementarities, resulting in both countries competing in similar products in global markets (Basu and Datta 2007a). That creates a problem for a smaller country like Bangladesh to compete against India which has a more diversified basket of export goods. (3) India is also found to dominate strongly in terms of bilateral trade at the aggregate level with stronger trade position vis-à-vis Bangladesh, resulting in a large and persistent trade deficit for Bangladesh against India.

In addition, (5) In terms of disaggregated data, we estimated and Analyzed the comparative advantage based RCA inter-industry trade for top eighteen (18) HS 2-digit product categories. In the estimated RCAi, (Revealed Comparative Advantage in industry i) methodology, India is found to have a much stronger comparative advantage in a larger number of major product categories than Bangladesh such that among the top eighteen (18) HS 2-digit product categories examined, India had positive RCA for 10 products (56\%) and Bangladesh with 8 products $(44 \%)$ of those product categories. This result is not a surprise give the size of the Indian economy and its much better resource endowments vis-à-vis Bangladesh.

Furthermore, (6) Bangladesh trade with India seems to be dominated by imports from India to the tune of about $89 \%$ of all trade with Bangladesh exports constituting only about $11 \%$ of all trade between them. (7) In spite of the fact that the annual average export growth seem to be slightly higher than its annual 
average import growth, a hopeful sign for Bangladesh to improve its trade deficit position in the future, however, given its smaller export base and smaller export share relative to import share in total trade, the deficit seems to be stubborn and persistent for Bangladesh. (8) Added to this large and persistent deficit in formal trade is the additional trade deficit of similar magnitude from informal trade between the two countries that makes the situation much worse from Bangladesh perspective.

Thus the deficit position is not only larger in terms of combined formal and informal trade, but also the deficits are persistent over time and these should a major concern for political leaders and policy makers in both countries. To achieve trade balance improvement faster, it seems clear that more positive policy action would be needed on the part of both countries to improve the trade imbalance of Bangladesh with India to make it sustainable in the long-run. Some policy actions may be that India, being the larger and stronger of the two countries, could take various policy actions to improve market access of Bangladeshi products into the larger Indian market. At the same time, Bangladesh needs to expand its export product lines so as to take advantage of such improved market access. These actions are expected to reduce the deficit towards a more sustainable level over the long-run, if not immediately.

\section{References}

Ahmed I (2006) Bangladesh-India Relations: The context of SAARC and the Emerging Global Scenario. Conference paper, Asian Affairs, April-June, 28(2): 46-62.

Akhtar HA, Salim R (1999) The Political Economy of Bangladesh's Large and Growing Trade Deficits with India. The Pakistan Development Review 38(1): 25-68.

Alam KA, Uddin MGS, Alam MM, Malakar B (2009) Trade Patterns of Bangladesh with India and China: An Empirical Evidence of the PPP Theory. Journal of Regional Economic Studies (2): 26-34.

Bakht Z (1994) BIDS study on Illegal International Trade in Bangladesh, 1990: An Update. Bangladesh Institute of Development Studies. Dhaka, Bangladesh, (mimeographed).

Bammi YM (2010) India Bangladesh Relations: The Way Ahead, Vij Books India Pvt. Ltd., India, 51-54.

Basu S, Datta D (2007a February) India-Bangladesh Trade Deficits and Misaligned Bilateral Exchange Rate: Can Bangladesh Draw Lessons from Indonesia? Journal of the Asia Pacific Economy 12(1): 76-102.

Basu S, Datta D (2007b January-June) India-Bangladesh Trade Relations: Problem of Bilateral Deficit. Indian Economic Review, New Series 42(1): 111-129.

Basher MdA (2013 April) Indo-Bangla Trade: Composition, Trends and Way Forward. Revised Draft paper, the Commonwealth Secretariat, 4-21.

Balassa B (1965 May) Trade Liberalization and Revealed Comparative Advantage. The Manchester School of Economic and Social Studies 33: 99-123.

Bhardwaj S (2014 June) An Agenda for the New Government: Policy Options for India in Bangladesh. Institute of Peace and Conflict Studies, IPCS issue brief no. 251. Retrieved from https://bit.ly/2pXfxnz. 
Bhuyan AR (2006) Bangladesh-India Trade Relations- Prospects of a Bilateral FTA. Thoughts on Economics 18(02): 8-34.

Chaudhari SK (1995) Cross Border Trade between India and Bangladesh. National Council of Applied Economic research (NCAER), Working Paper 58, New Delhi, India.

De P, Bhattacharyay BN (2007) Prospects of India-Bangladesh Economic Cooperation: Implications for South Asian Regional Cooperation. Discussion Paper No. 78, Asian development Bank, September, 1-36.

De P, Raihan S, Kathuria S (2012 August) Unlocking Bangladesh-India Trade-Emerging Potential and the Way Forward. Policy Research Working Paper, No 6155, The World Bank -South Asia Region Economic Policy and Poverty Sector, 1-33.

DCCI (2016) Data on Bangladesh and India Trade. Dhaka Chamber of Commerce and Industries. Retrieved from https://bit.ly/2PAeOnK.

Dutta P (2010) India-Bangladesh Relations issues, problems and recent developments. Institute of Peace and Conflict Studies, IPCS Special report, September, 97: 1-10.

Globaledge (2018) Globaledge database. Michigan State University. Retrieved from https://bit.ly/2ClYBPa.

Grubel HG, Lloyd PJ (1975) Intra-Industry Trade: The Theory and Measurement of International Trade in Differentiated Products. New York: John Wiley and Sons.

IBCCI (2016) India Bangladesh Trade. India-Bangladesh Chamber of Commerce and Industry. Retrieved from https://bit.ly/2yGSgdu.

Islam MM (2011 April-June) Trade cooperation between Bangladesh and India with Special Reference to the North-East India. Dialogue 12 (4). Retrieved from https://bit.ly/2J43BJn.

Islam RMG, Khan MT, Ishak A (2013) Bilateral and International Trade of Bangladesh and India: Effect of Falling Exchange Rate of Indian Rupee. European Journal of Business and Management 5(27): 33-39.

Islam A, Nuwal T, Nguyen C (2011) India's Economic Reforms and U.S. India Bilateral Trade Flows. International Journal of Global Management 1(2): 55-73.

Islam A, Dong H (2011 March) A Brief Overview of China's Global Trade performance. Southwest Review of International Business Research 22(1): 1-7.

Khan RM, Islam T, Ashiqun N, Paul TK (2010 July) Bangladesh's Export Opportunities in the Indian Market: Addressing Barriers and Strategies for future. Occasional Paper 90, Centre for Policy Dialogue (CPD) 1-26.

Mukherjee D (2015) India-Bangladesh: new trade links. Retrieved from https://bit.ly/ 2EFUT5V.

Pohit S, Taneja N (2000) India's Informal Trade with Bangladesh and Nepal: A Qualitative Assessment. Indian Council for research on International Economic Relations, New Delhi, India. Retrieved from https://bit.ly/2QZRVKO.

Pohit S, Taneja N (2003) India's Informal Trade with Bangladesh: A Qualitative Assessment. World Economy. Blackwell Publishing Ltd. 26(8): 1187-1214.

Pursell G (2007 June) Smuggling and Economic Welfare Consequences of an FTA: A Case Study of India-Bangladesh Trade in Sugar. Australia South Asia Research Center, Australian National University. Retrieved from https://bit.ly/2CoUf9W.

Pursell G, Sattar Z (2006) India-Bangladesh Bilateral Trade and Potential Free Trade Agreement, 1-96. Bangladesh Development Series Paper No: 13. The World Bank, World Bank Office Dhaka Bangladesh.

Rahman MM (2005 June) Bangladesh-India Bilateral Trade: Causes of Imbalance and Measures for Improvement. Research paper. University of Sydney, NSW, Australia. Retrieved from https://bit.ly/2Ow8sJt. 
Rather ZA, Gupta D (2014) India-Bangladesh Bilateral Trade: Problems and Prospects. International Affairs and Global Strategy 22(1): 42-48.

Razzaque MA, Basnett Y (2014) Regional Integration in South Asia: Trends, Challenges and Prospects, 1-518. London: Commonwealth. Retrieved from https://bit.ly/2PC $31 \mathrm{VT}$

Taneja N (2001 March) Informal Trade in SAARC Region. Economic \& Political Weekly 36(11). Retrieved from https://bit.ly/2pXJGDt.

World Bank (2006) India-Bangladesh Bilateral Trade and Potential for free Trade Agreement, 1-72. Bangladesh Development Series, Paper No. 13, The World Bank Office, Dhaka, Bangladesh.

World Bank (2015) Informal and illegal trade: dimensions, trends, composition, and the role of domestic indirect taxes. Chapter 8 , Retrieved from https://bit.ly/2CoTwFS.

World Bank (2018) World Development Indicators database. Washington DC, USA: World Bank. Retrieved from https://bit.ly/1eYCES4.

WTO (2018) Country Trade Profile, the World Trade Organization data base. Retrieved from https://bit.ly/1lH96ij. 


\title{
Bhoodan-Based Corporate Citizenship: Corporate Accountability Based on Serving and Empowering Land-Owners and Users
}

\author{
By Siddharth Mohapatra ${ }^{*}$ \& Pratima Verma ${ }^{\dagger}$
}

This paper attempts to conceptualize a corporate citizenship program in the context of land acquisition for commercial purposes in India. At present, instances of land acquisition related sustainability challenges are rampant, which have affected both business and society. Land related socio-economic impasses were also acute especially in India's post-independence era in the 1950's. Bhoodan (land-gift) movement, a fusion of servant leadership and social entrepreneurship, was by and large effective to address them. Considering its socio-cultural relevance, business can employ the tenets of Bhoodan to streamline the present situation. In this regard, we propose the Bhoodan-based corporate citizenship that can serve and empower land-owners and users, facilitate spontaneous land transfers, and streamline land acquisition for commercial purposes in India. Implications for research and practice are discussed.

Keywords: Bhoodan-based corporate citizenship (BbCC), land acquisition for commercial purposes, India, servant leadership, social entrepreneurship, spontaneous land transfers

\section{Introduction}

"Responsibility is the price of greatness." - Winston Churchill

The interests of business and society are intertwined. Corporate citizenship is a means in this regard e.g. (Schwab 2008). Corporate citizenship, a form of business ethics, underlines the social role of business (Crane et al. 2008). In line with the political concept of citizenship, it emphasizes on an organization's rights and duties in and for the business community (Logsdon and Wood 2002), i.e., business should act as a responsible citizen. However, business often sidelines its social responsibility especially in developing countries (Munshi and Kurian 2007: 439). The current contentious issue of land acquisition for commercial purposes in India (hereafter land acquisition) is such an instance.

India is the fastest growing major economy in the world (International Monetary Fund, IMF 2016). However, the current state of land acquisition is inefficient, unethical, and even illegal on many occasions. For example, land transfer is often marred by litigations over compensation and regulatory impediments obstructing voluntary land transactions (Singh 2012). Similarly, crony capitalism in the context of land acquisition is "one of the greatest dangers to the growth of developing countries..., which is harmful to free enterprise,

\footnotetext{
*Assistant Professor, Indian Institute of Management Kozhikode, India.

†Professor, Alliance University, India.
} 
opportunity and economic growth [and also] ... democratic expression.... [It is not only a problem... [of] individual ethics ... [but also] the [unethical] system we have" (Raghuram Rajan, quoted in The Times of India 2014). Streamlining unethical land acquisition business practices needs to address systemic bottlenecks.

Land acquisition mainly serves the interests of companies (Lobo and Kumar 2009). It often exerts pressure tactics, like big bucks investment appeals or threats of relocation, to obtain resource-rich land (Sethi 2002). It seeks lenient land regulations to circumvent socio-environmental impact analysis, fast-tracking projects, and lowering costs (Ahmed and Varshney 2012). The situation has further deteriorated due to contentious tenancy status, lack of consensus based land acquisition laws (Chakravorty 2013), land grabbing instances supported by business (Drèze and Sen 2013), public land being leased or sold to influential companies on favorable terms (Ghatak and Ghosh 2011), and subpar compensation and rehabilitation measures for land-owners and users (Chakravorty 2013). This has two implications. One, business is the dominant player in the land acquisition process. Two, land acquisition is marred by poor stakeholder management. India in turn ranks lowly on many business ethics indicators. For example, India is placed at 81 among 180 countries in Transparency International's (2018) Corruption Perception Index; unethical land acquisition practices do affect corruption significantly in India (Sahoo et al. 2014).

Since time immemorial, land is a contentious issue in India. The powerful socio-economic players have often suppressed the legitimate rights of the imperceptible ones while harnessing prosperity from land (Drèze and Sen 2013). The current socio-economic impasses related to land acquisition is not different either wherein companies have connived with the government to exploit the landowners and users. However, to have the rights to remain a going concern, business should discharge its duties like a good citizen-corporate citizenship (Crane et al. 2008). With the backdrop of the current unsustainable land acquisition practices, we attempt to conceptualize a corporate citizenship program to address land acquisition related impasses.

In the aftermath of independence, the Bhoodan (land-gift) movement was lunched to address a similar situation. Drawing parallels between India now and then, we borrow tenets from Bhoodan into the domains of corporate citizenship to undertake this study that is organized as follows. We first review the current state of land acquisition from social, political, and economic perspectives. Then we analyze Bhoodan under the rubrics of servant leadership and social entrepreneurship. We subsequently discuss the role of corporate citizenship based on Bhoodan-Bhoodan-based corporate citizenship (BbCC) - as enabling citizenship rights to land-owners and users. Thereafter, following the literature on corporate citizenship especially Crane et al.'s (2008) extended corporate citizenship, we conceptualize the Bhoodan-based corporate citizenship program that is led by business, which can serve and empower the land-owners and users, facilitate spontaneous land transfer, and create a win-win situation for business and society. 


\section{Study Design and, Research Method and Methodology}

Although land acquisition related poor stakeholder management is a recent issue, its roots lie in the social and cultural milieu of India. Bhoodan was an attempt to address various historical injustices underlying land related socioeconomic impasses. As historical data provide critical contextual link of the past to the present, we have undertaken historical research and used bibliographic method (Howell and Prevenier 2002). To minimize literature selection bias particularly spectrum bias and random error, we have reviewed studies on multiple stakeholders and undertaken dual review respectively (e.g. Collier 1995).

Further, BbCC is a corporate citizenship program, which is based on Bhoodan. This implies that the initial strategy to reach the final state is largely unknown and should ideally be deduced from existing concepts (see Watanabe 1972). We have employed retroductive approach as the methodology and drawn tenets from servant leadership and social entrepreneurship to conjecture event causality of Bhoodan and predict generative causality of BbCC respectively (see Mingers and Standing 2017). Retroduction is a viable means in studies like ours because it is a theory building study, not theory testing one (McKay 1976).

\section{The Current State of Land Acquisition in India}

Land acquisition for economic development in India has affected business, government, people and environment (Ahmed and Varshney 2012). This is elaborated as follows.

\section{Land Acquisition and, People and Environment}

Agriculture currently employs nearly 56.6 percent of the population in India but accounts for only 15 percent of GDP (Planning Commission of India 2014). Hence, policymakers encourage transition from agriculture to manufacturing and service sectors (Bhagwati and Panagariya 2013). Since independence, India has embarked on urbanization and industrialization for economic growth, which have led to large scale acquisition of land (Chakravorty 2013). Between 1951 and 1995, more than 50 million acres of land, nearly 10 percent of India's usable land, were acquired and converted for these projects (Fernandes 2004). More than 60 million people have lost land, livelihood, common properties, and leased contracts between 1947 and 2000 (Fernandes 2008).

In many instances of land acquisition, land-owners and users merely remain mute spectators (Sarkar 2012). The following remarks by a tribal, affected by land acquisition for mining, are disturbing.

"We worshipped the forest god. We got all our firewood from here. This place was green, now it is black with dust.... When agricultural land is lost, what are we supposed to eat? Coal" (Amnesty International 2016: 62)? 
There are many such instances in India's rural and tribal areas (Drèze and Sen 2013). Although compensation is paid in urban areas, it often gets mismanaged. The story of a farmer in Gurugram, which has offices of 300 of Fortune 500 companies and is the IT hub of North India, tells it succinctly (Business Standard 2013).

"I got ... [300 thousand US dollars] by selling nearly three acres of agricultural land [that is part of urban Gurugram now].... I purchased six acres [of land in rural Gurugram,] ... built ... a ... bungalow and bought a SUV.... I never thought that money would finish one day.... Now I am working as a private security guard in a building on my own land."

On one hand, farmers are in a hurry to quit farming, move to the city, and create fortunes for themselves; on the other hand most of them being illiterates do not understand the long-term implications of selling land (Narain 2009). They often overspend compensation money without creating regular income sources and lose everything (Levien 2011). Hence, land acquisition related compensation, resettlement, and rehabilitation needs to be improved.

On many occasions, compensations are meagre and erratic. The government, to keep project costs low, often sets low acquisition prices (Chakravorty 2016). In every six out of ten cases appealed against low acquisition prices, the Supreme Court of India increases compensation, sometimes up to ten times of the original amount (Hindustan Times 2016). Often, the farmer receives only one quarter of the cost of the land as compensation and the rest goes as subsidy to the buyer (Hindu 2015). Discontents emerge even after land is transferred; as market prices soar due to the usual post-acquisition development spree, erstwhile owners get dejected (Levien 2011). In the process, millions of long-standing land dispute litigations are pending in courts. Land related litigations usually take decades for settlement (Supreme Court of India 2016). Hence, apart from compensation, they involve loss of pay, wasted business opportunities, legal expenses, and emotional ordeals (Chakravorty 2016).

Adivasis (aborigines) and dalits (untouchables) are the worst affected in land acquisition (Drèze and Sen 2013). Their land is not considered acquired because most of them use common property resources, like forest and sea, for livelihood (Chakravorty 2016). These land acquisitions are less likely to be challenged in courts (Ghatak and Ghosh 2011). Consequently, they lose traditional livelihoods and do not get compensation. For example, the fishermen from the displaced fishing villages near Adani Group's Mundra port and SEZ fear that they would not be given access to the sea once the port is fully functional. Thus, compensations do not include lost livelihoods. Ghatak and Ghosh (2011: 66) argues that "the market price is not an adequate anchor for compensation, and this ad hoc formula will guarantee neither social justice nor efficient use of a scarce resource, notwithstanding its pro-poor appearance." Consequently, many land-owners and users suffer immensely and even commit suicide (Dias 2009). Landownership being an emotional issue for Indians, it is also argued that the valuation of land should not only be determined by the opportunity costs or market prices but also 
additional factors, like emotional attachments to and social identity arising from landholdings (Porwal and Singh 2011).

Furthermore, On many occasions, community-level cronyism, where the government and corporations create divisions by favoring some groups and ignoring others, has also jettisoned collective action by the affected people that is usually effective in Indian (Levien 2011). Thus, the cost of land acquisition to individuals, communities, and environment are ominous.

\section{Land Acquisition and Government}

Till 2013, land acquisition in India was governed by the colonial-era Land Acquisition Act of 1894. Post-independence, eminent domain was used to avoid huge transaction costs. State often forcibly acquired private properties for public purpose by paying just compensations even if the owner did not want to sell (Chakravorty 2016). Hence, it was an anti-people law. In 2013, the Indian parliament passed the Right to Fair Compensation and Transparency in Land Acquisition, Rehabilitation and Resettlement Act, 2013 (RFCTLARR13), with stringent clauses against forced acquisition (Chakravorty 2016). Under RFCTLARR, land acquisition roughly used to take 4-5 years (NITI Aayog, n.d.). Hence it was viewed as antibusiness and antidevelopment. This prompted the present government to amend (RFCTLARR13) to RFCTLARR (Amendment) Bill, 2015 (RFCTLARR15) (Chakravorty 2016).

Amendments like removing the mandatory social impact assessments and 80 percent consent of community before acquiring were aimed at reducing the acquisition time, lowering the indirect costs of acquisition, and attracting investment (Chakravorty 2016). Opposition parties have accused the government of indulging in cronyism; its passage in the Indian parliament through consensus is still a daunting task (Indian Express 2016). To continue economic development, some state governments are bypassing existing laws, even promulgating their own laws to fast-track land acquisition, flouting social and environmental norms on many occasions (Reuters 2016). Such fast-paced reforms however can create sustainability challenges. For instance, there are arguments like "land acquisition by the Indian state ... [has been] a profoundly regressive process - it redistributed the benefits of land use from the poor to the less-poor and the non-poor" (Chakraborty 2016: 55)—instances of Raghuram Rajan's state-sponsored cronyism (Times of India 2014).

Furthermore, land acquisition fall under the jurisdiction of both center and states. With no consensus in sight, it can lead to constitutional crises if some state governments violate RFCTLARR13 and the central government, say from a different political party, contests it; this would ultimately undermine the federal structure of India (Goswami 2016). Considering various political, constitutional, and governance implications of land acquisition, the vice chairman of the central planning commission of India in the recent past has said, "Land acquisition [is] a difficult task in India” (Economic Times 2015). 


\section{Land Acquisition and Business}

In the recent past, there have been violent agitations against companies acquiring land, notably Tata Motors in Singur, Posco in Jagatsinghpur, Mukesh Ambani Group in the outskirts of Mumbai, and Adani Group in Mundra. Even there are organized armed rebellions against business in the Naxalite infested areas in central India (Hardiman 2003). Nearly 90 percent of all the land acquisitions are for government projects (Lobo and Kumar 2009). However, many of these projects like mining, energy, industrial corridors, smart cities, high-speed rails, SEZs, ports, and airports mainly benefit business. Thus, questions are increasingly being raised concerning why the state should acquire land for business (The New York Times 2015, cf. NITI Aayog, n.d.).

Streamlining land acquisition is easier said than done because the public is still distrustful of government and companies due to past abuses (e.g., Nielsen 2015). Moreover, due to the proposed changes in RFCTLARR15, people are apprehensive that their land would be forcibly acquired for meagre compensations (The New York Times 2015). Interestingly, there are estimations that people could make a lot of money, up to " 25 times or maybe 100 times more than they're going to get from farming in perpetuity," if they transfer land (The New York Times 2015). This however can happen only if RFCTLARR15 is implemented fairly. Tracing the history of legislation-based, state-governed, top-down land acquisition approach in India presents a gloomy picture in this regard (Somayaji and Talwar 2011). Hence, to streamline land acquisition, there are growing demands to take various stakeholders into confidence (Bardhan 2011, Michael and Baumann 2016, Narain 2009, Nielsen 2015). A similar situation prevailed in the aftermath of India's independence, which was addressed by Vinoba Bhave through the Bhoodan movement (Bornstein 2007).

\section{Bhoodan: A Voluntary Land Reform Movement in India}

Vinoba Bhave was an important figure in the Indian freedom struggle. He is the recipient of the first Ramon Magsaysay Award for Community Leadership and the Bharat Ratna, India's highest civilian award (Figueroa 1997). He had taken the vow to bestow selfless service to the mankind (Jaffrelot 2012). In March 1948, he, along with many other followers of Gandhi, created the Sarvodaya Samaj or the society of welfare-for-all (Jaffrelot 2012) to realize Gandhi's dream India- the Ram Rajya ${ }^{1}$.

At the time of independence, India was an agrarian society (Singh 2009). Nearly 70 percent of its population lived in villages and agriculture was the single most important factor influencing the growth of the national income (Singh 2009). "In ... [an agrarian] society land is more than just another factor of production.... $[\mathrm{I}] \mathrm{t}$ is the long term security of the family against the hazards of life, and it is part of the social status of the family within village or community" (Ellis 1993: 8).

\footnotetext{
${ }^{1}$ A utopian society without misery, sorrow, and distress
} 
Hence, landownership was not an economic but also social and cultural factor in India. Over 60 percent of the households in rural India however were either landless or owned meagre acres of land (Chandra et al. 2008: 509). The land-man ratio in rural India was 0.92 acres (per capita), which was considered very low in comparative standards (Chandra et al. 2008: 509). Tenancy made this situation more complicated, comprising of complex layers of possession, leasing and tilling. This was due to the zamindars (absentee landowners) in the Northeast, small landholding owner-cultivators in the Northwest and varying degrees of ownership and leased-farming in the South, West, and Central India (Varshney 1998). Moreover, upper caste people owned more land than the lower caste (Singh 2009). Furthermore, the British colonizers arbitrarily distributed land rights to rich landlords through Permanent Settlement Act of 1793 mainly to garner their support toward the continuance of the British rule in India (Drayton 2000). As a result, the lower stratum of society was subjected to the most grievous oppression. Abysmally, the British colonizers treated India as a raw material producing colony and a consumer base; they did not do much toward land reform (Drayton 2000). There were many uprisings against landlords, which continued in the postindependent India (Brass 1994).

To create a just and equitable society, Vinoba embarked on a series of reformist movements under auspices of the Sarvodaya Samaj. In 1951, in response to growing peasant revolutions all around India, he launched Bhoodan - an extraordinary and unprecedented socio-economic developmental endeavour for 'land reform' in the recorded history - to contain violence through non-violence (Chandra et al. 2008). It was an attempt to solicit voluntary land transfer to create an equitable society (Dutta Mishra and Narayanasamy 2009: 252).

"In a just and equitable ... society, land must belong to all. That is why we do not beg for gifts, but demand a share to which the poor are rightly entitled. The main objective is to propagate the right thought, by which social and economic maladjustments can be corrected without serious conflicts."

Vinoba, with many fellow Gandhians, walked through villages, persuading landlords and landowners to donate land to landless cultivators to restore amity in society (Dutta Mishra and Narayanasamy 2009).

The mission of Bhoodan was "to bring about a sarvodaya social orderGandhi's vision of a stateless society devoted to the welfare of all and founded on non-violence, equality and decentralization" (Church 1975: 94). Land was donated voluntarily and distributed according to need (Figueroa 1997). Although by the end of 1956, more than 4 million acres of land had been collected against a target of 50 million acres, "it was enough for people to consider the movement one of the most significant in India's history" (Figueroa 1997: 44). Additionally, to scale up Bhoodan, he launched Gramdan (village-gift), Jivandan (Gift of life), Sampattidan (gift of the wealth), Shramdan (gift of labour), Shanti Sena (Army for Peace), and Sarvodaya-Patra (the pot where every household gives handful of grain daily) (Church 1975). 


\section{Bhoodan: Servant Leadership Influenced Social Entrepreneurship}

According to William Drayton, the founder of Ashoka, "[Vinoba is] a social entrepreneur" (Bornstein 2007: 53). Social entrepreneurship is a fusion of altruism and entrepreneurship (Nicholls and Cho 2006). Social entrepreneurs "see a bad situation, envisage a better one, and work out how to get from ... [bad] to [better]" (Clark 2009: 20-21). They identify opportunities, strategize innovative means, and mobilize resources (Economy 2002) to create "sustainable improvements" (Dees 1998: 5) and diversify to create further improvements (Dees et al. 2002). Lastly, they spread these transformations to other regions to create multiplier and ripple effects (Bornstein 2007). As regard their success, "quality of motivation" is crucial, which are: a willingness to self-correct (themselves and their social enterprises), sharing credits, breaking free from established structures, going beyond disciplinary boundaries, working quietly yet steadfastly, and having strong ethical impetuses (Bornstein 2007). To be effective, social entrepreneurship needs the spirit of servant leadership (Kitzi 2002, Greenleaf 2002[1977]). The key elements of social entrepreneurship therefore are: change agents, social problems, opportunity, innovation and resource mobilization, sustainability, transformation, social impact, multiplier effect, and, importantly, servant leadership (Meehan 2004). Next, we discuss them in the context of Bhoodan.

Immediately after India's independence, Vinoba founded the Sarvodaya Samaj to create an equitable society. Hence, he was a visionary and a change agent. He identified that "the solution to India's problems ... [was] land distribution" (Time 1958). Thence, he created Bhoodan. His target was to get 50 million acres of land in five years (1953-57), to be distributed among 50 million landless (Venkatasubbiah 1961). In this way, after identifying the problem, he seized the opportunity to create social change. Importantly, he diversified Bhoodan to increase its effectiveness.

Vinoba had renounced all his material property. Gandhi once had remarked, "Vinoba ... has acquired a degree of spirituality and asceticism that took me years of patient labour to attain" (Jayapalan 2003: 219-220). He had charisma and massappeal, mainly because he was regarded as Gandhi's spiritual heir (Sabin 2002). Moreover, he featured in the Time (1953) magazine cover. His strength was to pull people toward Bhoodan. To encourage land donation, he appealed the landlords as follows: "Like air and water, land belongs to God. To claim it for oneself alone is to oppose the very will of God. And who can be happy if they oppose His will" (Tennyson 1955: 71)? In this manner, it attempted the "ideas of trusteeship and fraternity as means of [social] reform, rather than legislations" (Brown 2000: 167).

Bhoodan was launched from the Telangana region, after the state government of Andhra Pradesh, the Indian Army, and landlords ruthlessly suppressed the Telangana Movement (1946-51) — one of the most widespread, fierce, and long lived peasant movements - in 1951 (Brass 1994). Thus, the timing was apt to send a strong message to the government and landlords about their crimes and the place was appropriate to show his solidarity with the landless. Vinoba's creativity was his simplicity. He used common man's language and day to day communication style to mobilize resources. 
'To those who have land ... [Vinoba] says: "I have come to loot you with love. If you have four sons, consider me as the fifth, and accordingly give me my share." To impoverished tenants and landless laborers ... [he] says: "We are all members of a single human family" (Time 1953).

Sustainability of Bhoodan lay on its multiple stakeholders and the emphasis on giving. For instance, Vinoba not only accepted 100,000 acres from a Maharajah (king), but also a tiny patch of one fortieth of an acre of land donated by a Telangana peasant who owned only one acre himself (Time 1953). Thus, he engaged the common man as well as their erstwhile rulers in Bhoodan. He also involved the policy makers in it. For instance, Jawaharlal Nehru, the first Prime Minister of India, acknowledged that land belonged to all and private ownership must end, and sought Vinoba's help "to find for India a way of raising food production and the peasant standard of living" (Time 1958).

The social impact of Bhoodan was mixed, though. By 1967, when Vinoba withdrew himself from Bhoodan, 4.27 million acres of land were donated (Dutta Mishra and Narayanasamy 2009). 1.19 million acres of land were distributed (which was far more than what the government had done), 1.73 million acres were barren, and 1.34 million acres remained undistributed (which included disputed land) (Dutta Mishra and Narayanasamy 2009). In most of the cases, landlords often donated land that was either uncultivable or litigated (Dutta Mishra and Narayanasamy 2009). The land thus obtained and distributed were far less than the target of 50 million acres. Yet, Bhoodan succeeded "in bringing about [changes] in [landlords'] attitudes through [their] feelings of guilt" (Weber 2004: 154).

Furthermore, many national and state level land reform legislations were promulgated under the direct and indirect influence of Bhoodan. The Zamindari Abolition Act (1950-70) under which intermediaries (mainly the landlords) between the State and the actual tillers were removed, thereby bringing nearly 20 million cultivators into direct contact with the government and some 5.77 million hectares (or ten thousand square meters) of land was distributed in the process (NCAS 2005). Several state laws were enacted between 1960 and 1972 to initiate tenancy reforms as regard security of land tenure, rent regulation, right of ownership, and land ceiling limits (NCAS 2005). Bhoodan also created multiplier effects by influencing many socio-economic developmental programs in Asia and Africa; especially was instrumental in the creation of the Sri Lankan Sarvodaya Movement (Melkote and Steeves 2001) that strived for various grassroots empowerment programs in Sri Lanka.

Furthermore, social entrepreneurship attempts to create permanent change in society. Hence, it entails "changing the character and attitude of individuals concerned[;] ... change by force, without a "change of heart," merely substitutes one master or evil for another' (Brown 1961: 20-21, see also Dees 1998). Servant leadership often plays a critical role in social change programs (Hickman 2010), including social enterprises (e.g., Martin and Novicevic 2010). Servant leadership has nine functional attributes, namely: vision, honesty, integrity, trust, service, 
modeling, pioneering, appreciation of others, and empowerment (Russel and Stone 2002). Let us discuss them in the context of Vinoba led Bhoodan.

Figure 1. Bhoodan: An Instance of Servant Leadership and Social Entrepreneurship

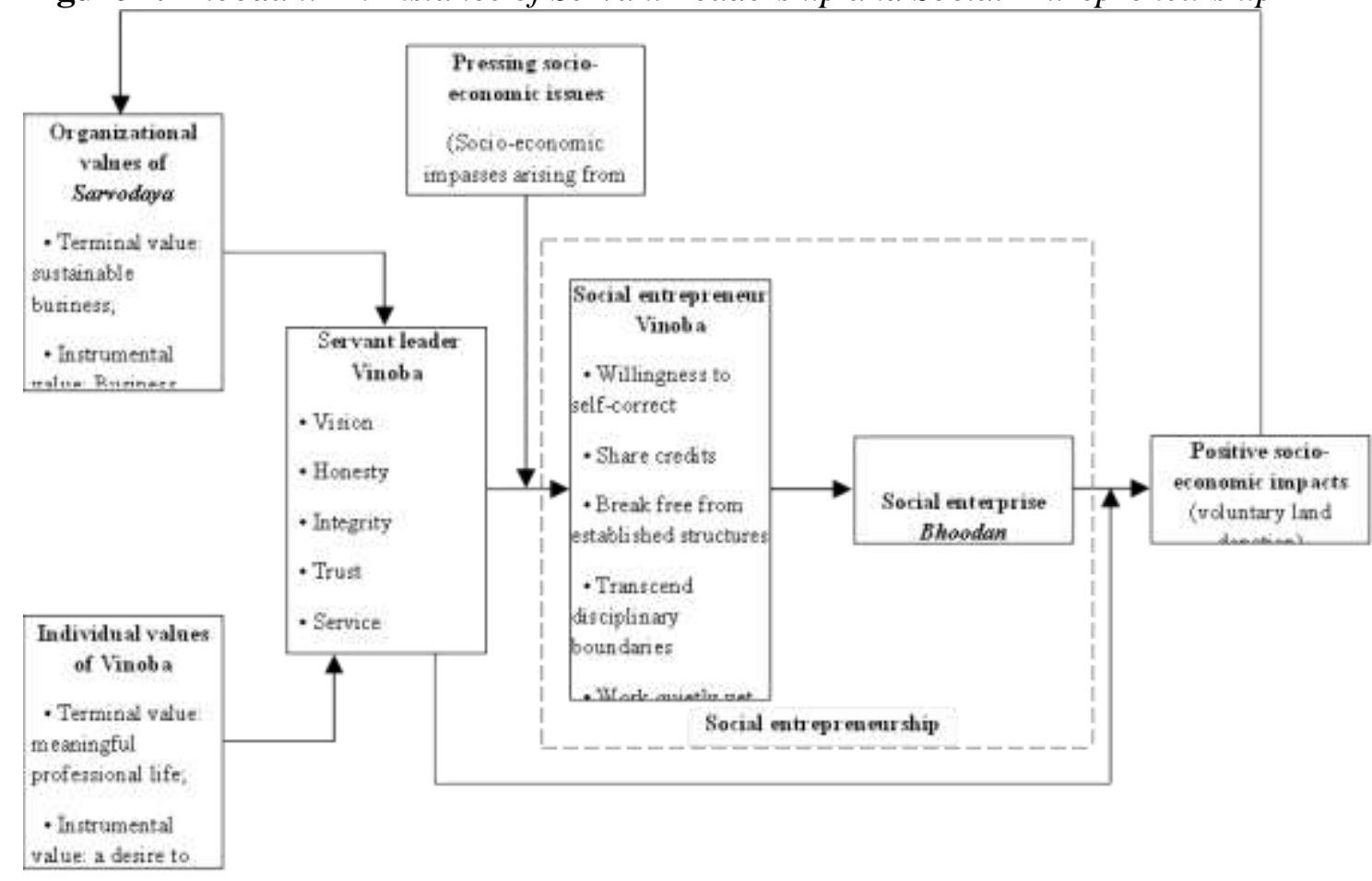

Source: Van Dierendonck (2011: 1233); Russel and Stone (2002: 154).

\section{The Other Side of Bhoodan: A Critique}

Bhoodan was timely, strategic, and produced social impacts with mixed results. In the 1950s and 1960s, when rural India had a sizeable share in the national economy and when most parts of India was reeling under violent peasant unrests, land reform was important. He therefore launched Bhoodan. In the early 1960s, when eastern India faced a major food crisis, he diversified focus toward fostering cooperation among people and increasing land productivity by creating Shramdan (Bandyopadhyay 2008). And, when Bhoodan sensitized the government machinery about the importance of equitable land ownership, which promulgated land reform laws, he scaled down Bhoodan in 1967. 
Table 1. SWOT Analysis of Bhoodan

\begin{tabular}{|c|c|}
\hline Strengths & Weaknesses \\
\hline $\begin{array}{l}\text { 1. Futuristic vision and time-bound objective } \\
\text { mission } \\
\text { 2. Organizational strength, resource } \\
\text { mobilisation, creative strategy, servant } \\
\text { leadership, and passionate involvement (of all) } \\
\text { 3. Apt timing and launching } \\
\text { 4. Stakeholder diversity } \\
\text { 5. Direct, personal and face-to-face interaction } \\
\text { 6. Inclusive form of governance and } \\
\text { management }\end{array}$ & $\begin{array}{l}\text { 1. Lofty goals } \\
\text { 2. Absence of clarity regarding the objective } \\
\text { 3. Mostly one-man show and taken-for- } \\
\text { granted personal beliefs of the leader } \\
\text { 4. Being operational in a society } \\
\text { overcrowded with too many problems } \\
\text { 5. Initial success led complacency } \\
\text { 6. Ran into many other programs } \\
\text { 7. Operating under more emotional beliefs, } \\
\text { and less rational thoughts } \\
\text { 8. Non-existence of a Plan B }\end{array}$ \\
\hline Opportunities & Threats \\
\hline $\begin{array}{l}\text { 1. Futuristic vision led sustainability and } \\
\text { objective mission led short-term success } \\
\text { accomplishment } \\
\text { 2. The evolution of the 'sprit of volunteering' } \\
\text { among Indians }\end{array}$ & $\begin{array}{l}\text { 1. Goal waywardness and difficulties in } \\
\text { impact assessment due to overcrowding of } \\
\text { programs } \\
\text { 2. Absence of an alternative plan and hence } \\
\text { project's weaker self-adjustment possibility }\end{array}$ \\
\hline
\end{tabular}

Source: Author.

Bhoodan had its shortcomings too. (See: Table 1) First, up to three-fourths of the collected land was due to the personal influence of Vinoba; when he withdrew from the Movement, "it lost its mass base" (Hazra 2006: 33). Second, landlords mostly donated unproductive land, evaded the land ceiling regulations, and betrayed Bhoodan in the process (Nedumpara 2004). Third, Bhoodan was financed by regional governments in India, like Bihar, to frustrate the demands of peasants (Nedumpara 2004). Fourth, the distribution of Bhoodan land was often lengthy and intricate (Linton 1972). Fifth, many meagre land-holders gave away land under Bhoodan, and expected more land under Gramdan (Church 1975). Sixth, the relationship between the landowners and landless was far from cordial in many cases; thus, removal of social and economic barriers did not happen (Nanekar and Khandewale 1973). Seventh, in the absence of financial assistance, the poor peasants were exploited by traditional money lenders who were landlords (Nanekar and Khandewale 1973). Eighth, Bhoodan had a diverse stakeholder profile; however, a movement, to be successful, should have support from fairly homogeneous groups (Oommen 1972: 77). Ninth, some of the most important Bhoodan leaders used their clout to launch anti-governmental activities to gain political mileage (Nedumpara 2004). Tenth, Bhoodan became a "system maintaining device" (Oommen 1972: 3) - it served the feudal interests of the rich (landlords) - because the land that were donated under its auspices became government land under Zamindari Abolition Act and hence could not be distributed under Bhoodan (Oommen 2009 [1969]). Vinoba also acknowledged that Bhoodan's tilt toward the rich instead of the poor was fundamentally flawed, because the rich almost did everything to defeat its purpose (Bhave 2009 [1969]). Furthermore, the servant leadership served the cause of Bhoodan well in the initial period. When the movement became bigger and complex, e.g., the introduction of Gramdan, Vinoba should have adopted transformational leadership (Smith et al. 2004). 
Furthermore, Bhoodan's shortcomings chiefly led to the "second awakening of peasant movement" or the Naxalite movement in the late 1960s, when peasants demanded the implementation of land reforms, which still is continuing (Hardiman 2003: 207-210). The landlords also created their own armed gangs, in some cases with the support of the government, which is still prevalent (Nedumpara 2004). Hence, Bhoodan could not create amity between the landlords and the landless. Moreover, the landlessness has not been addressed till date. The Eleventh Five Year Plan ${ }^{2}$ (2007-2012) reveals the continuance of oral and concealed tenancy in rural areas. As a result, tillers' position remains precarious (Planning Commission, Government of India: 67). This has raised serious doubts about the effectiveness of land reform. Notwithstanding, Bhoodan is appreciated as "the first step [toward] ... a total revolution [to create a fair and equitable society]" (Sherman 2016).

\section{Bhoodan-Based Corporate Citizenship (BbCC)}

Bhoodan was launched to solicit voluntary land donations when agriculture was the lifeline of the economy. Things at present are different, though. The World Bank (2015) data reveals that the overindulgence in the occupations in the primary sector, like farming, has resulted in India's low per capita GDP. Although, India's economic growth has reduced poverty (Bhagwati and Panagariya 2013), it still has 380 million people who live on less than a dollar a day (Kornblum 2012). Hence, India's policymakers are emphasizing upon manufacturing and service sectors for economic development.

Since independence, successive governments have emphasized on urbanization and industrialization for economic growth (Bhagwati and Panagariya 2013). India is currently the fastest growing major economy in the world (IMF, 2016). This momentous growth is the outcome of largescale industrialization, urbanization, and infrastructure projects (World Bank 2016), which involve massive statemanaged land acquisitions (Chakravorty 2013). But land acquisition through eminent domain is emerging as "India's 'biggest problem"" because it has created poor stakeholder management (Chakravorty 2016: 49). Consequently, the judiciary and legislature are at loggerheads. For example, on a petition filed by farmers, the highest court of Madhya Pradesh recently quashed land acquisition by the state to develop an industrial park (Times of India 2017). Thus, land acquisition "has now become a major bone of contention between farmers and those who need land for commercial [purpose]; ... leading to social unrest and violence" (Bardhan 2011: 55). People are distrustful about government and business regarding land acquisition. This is a situation marred by trust deficit between the haves (land-owners and users) and the have-nots (those who need resource rich land), which is similar to India's post-independence era. Noting the similarities between now and in the 1950s, we argue that the tenets of Bhoodan are useful here.

\footnotetext{
${ }^{2}$ The Indian economy is based in part on planning over five year durations.
} 
On the one hand, land is needed to be transferred for commercial purpose; it should be done amicably for the long-term progress of all, on the other. Like Vinoba, business can see this situation as an opportunity. In this regard, we propose a corporate citizenship program based on servant leadership influenced social entrepreneurship: Bhoodan-based corporate citizenship (hereafter BbCC). (BbCC is in line with Figure 1.) Whereas Bhoodan was an attempt to create voluntary land donations because the poor landless population was its major beneficiary, $\mathrm{BbCC}$ is proposed to facilitate spontaneous land transfers. This is because land is transferred by the land-owners and users who are mainly poor and marginalized; hence, they need compensation to have better and alternative livelihoods. To overcome weaknesses and threats concerning Bhoodan, we propose corrective mechanisms into BbCC.

\section{Corporate Citizenship and Structural and Functional Aspects of BbCC}

According to Crane et al. (2008), companies as extended citizens, instead of the governments, can provide social, civil, and political rights to people. They can facilitate welfare rights for ordinary citizens, further (or suspend) human rights, or act as channels through which citizens may express their political opinions and exercise their political rights. $\mathrm{BbCC}$ is based on this extended corporate citizenship program.

$\mathrm{As} \mathrm{BbCC}$ is a vehicle to further commercial interests of business as well as meet the social and economic aspirations of people, BbCC's leader should be ideally a company insider having the traits of both a servant leader and a social entrepreneur. To instill legitimacy and authority into the servant leader, company's top decision-makers along with chief sustainability officer and chief human resource officer should oversee the selection process. Following Boehm (2002), we assume that chief sustainability officer can represent the local community which is critical for the effectiveness of socially responsible programs.

$\mathrm{BbCC}$ attempts to create a social enterprise that facilitates spontaneous land transfers by the land-owners and users. Its servant leadership side ensures fair compensation and the social entrepreneurship side its prudent usage for sustained income. In addition to company personnel, it comprises of diverse stakeholders like land-owners and users, community opinion leaders, social reformers including religious leaders, NGOs, local politicians, government bureaucrats at the village and district levels like the police, like-minded industry representatives, and the United Nations Global Compact (UNGC). The UNGC not only aims to create a more sustainable and inclusive world but also, being a United Nations body, is respected and trusted. It is argued that such a multi-stakeholder oriented social enterprise is helpful to address pressing social problems (see Sud et al. 2009). For effectiveness, the BbCC leader, like Vinoba, should create a coalition constituted by members from the above stakeholder profile, which can create the social change, i.e., spontaneous land transfers (see Kotter 1996: 66). Coalition size may be determined as per requirement. When the program needs fast-tracking, the BbCC leader should employ a small group because smaller groups are faster at completing tasks, and if the goal is fact-finding, larger groups should be employed 
(Robbins and Judge 2013). BbCC should be named uniquely, say, an important local cultural aspects, which can foster members' identity toward it (Tajfel and Turner 1979).

Let us now discuss the functional aspects of BbCC. After studying the situation related to land acquisition, the BbCC leader, with the help of the stakeholder coalition, should spread awareness and create a "sense of urgency" (Kotter 1996: 42-44) among the stakeholders about the importance of resource rich land for a thriving business that eventually can lead to community prosperity and national progress. This, we anticipate, would lessen local hostility toward business (see Boehm 2002) and also bestow social rights (right to education) to landowners and users (Crane et al. 2008), e.g., skill building education and money management and training programs for the land-owners and users.

As land is an emotional issue in India (Porwal and Singh 2011), land acquisition should not merely emphasize upon a "profit first" motivation; rather, it should be done with "the sole purpose of achieving a union of hearts [between business and the landowners by strategically aligning their interests]" (Shepard 1987: 11). The BbCC leader and the coalition should be aware of and abide by the legal aspects regarding land acquisition, e.g., analyzing environmental impacts, giving fair compensations, obtaining eighty percent land-owners and users consent, and so on, which can bestow civil rights (right to property) to landowners and users (Crane et al. 2008). BbCC should not indulge in "land grabbing" which will defeat the entire process. Thus, it should give political rights (right to dissent) to land-owners and users (Crane et al. 2008). This means, its modus operandi should be transparent and it should be accountable to the community.

All along, the BbCC leader should be careful about being focused on the task in hand, i.e., spontaneous land transfers, and as far as possible stay away from other socio-economic issues in the community. The BbCC leader should always look for avenues to self-correct the corporate citizenship program like pursuing alternative plans and even disbanding the program altogether if the need arises. Finally, we argue that the positive socio-economic impacts in the form of actual spontaneous land transfers can influence organizational values, transform organizational culture, and make an organization a 'good' corporate citizen (see Schein 2010). This can create social legitimacy, enhancing the organizational trustworthiness as a sustainable societal change agent in the process.

\section{Discussion, Contributions, Limitations, and Future Research Directions}

India's current land acquisition practices are unsustainable. Trust deficit due to past abuses between land-owners and users on one side and, the government and business on the other is a major stumbling block to streamline this impasse. Doing business as usual by accommodating the interests of traditionally powerful stakeholders, like government and business, and ignoring the interests of imperceptible stakeholders, like the land-owners and users, has created poor stakeholder management. This is a situation of lost opportunities for both business and society. Top-down approaches employing social, economic, political, and 
legal means have not improved the situation. Hence, we have suggested a multistakeholder grass-root centric means to bridge trust deficit between land-owners and users and business. Borrowing tenets from Bhoodan and employing servant leadership and social entrepreneurship, we propose BbCC as an extended corporate citizenship program that can enable spontaneous land transfer by the land-owners and users, thereby streamlining various impasses in the land acquisition. In particular, following van Dierendonck (2011), we conceptualize $\mathrm{BbCC}$ bestow social, civil, and political rights to land-owners and users like Bhoodan as a as a social enterprise, which we posit can facilitate spontaneous land transfer. In the process, we make several contributions to research and practice.

\section{Theoretical Contributions}

BbCC can contribute to the literature on justice in general and justice as fairness in particular It satisfies Rawls' (1971[1999]) justice as fairness in the following manner. It ensures that economic equity must not override social equality. This is important because "social and economic gains (permitted by the second principle) cannot be achieved by sacrificing the equal scheme of basic liberties (specified by the first principle)" (Mandle 2009: 48). In this context, bestowing social, civil, and political rights to land-owners and users through BbCC is an attempt to satisfy Rawls' (1971[1999]) principle of liberty (Barry 1973), which can create spontaneous land transfers leading to satisfying the boundary conditions of Rawls' (1971[1999]) difference principle (Beauchamp 1980, Feldman 1996, Nozick 2013 [1974]).

\section{Practical Implications}

From the practitioners' perspective, business can immensely benefit from $\mathrm{BbCC}$. At present, there are severe trust deficits between business and land-owners and users because of the past atrocities (Ghatak and Ghosh 2011). BbCC can be act as a justice restoration mechanism in society, which can make business once again a trustworthy social institution. In this regard, the most prominent feature of $\mathrm{BbCC}$ is the collective decision-making process to acquire land, which can create a bottom-up democratic approach to facilitate spontaneous land transfers. Additionally, BbCC can serve the interests of land-owners and users by bestowing upon them social and civil rights; and empower them by bestowing upon them political rights (Kell and Levin 2003, Berlin 1969). Thus, BbCC underlines that sustainable land acquisition needs corporate citizenship programs in countries like India that should first create conducive conditions for social projects by employing servant leadership and then spread them through social entrepreneurship (see Martin and Novicevic 2010).

\section{Limitations and Future Research Directions}

This is a conceptual paper that is based solely on a review of the extant literature. For future research, an empirical study can be conducted to obtain the 
veracity of BbCC. Further, there are limitations regarding BbCC as an extended corporate citizenship program. Although Goyder (1961) advocates that socially responsible business is 'good' business in the long run, Korten (1984) cautions that markets would discipline companies which are financially irresponsible and loss-making, despite being socially responsible. Hence, BbCC needs careful analysis of different societal (e.g., pressing socio-economic issues), organizational (e.g., organizational values), and individual (e.g., values and leadership styles) variables as its constituents. These interactions can also uncover different opportunities and threats of employing $\mathrm{BbCC}$ to streamline land acquisition related impasses, which can shed additional insights. For example, when BbCC encounters situations where societal norms and structures have led to a heavily ossified social problems, it may be "ecologically rational" to adopt constructive rule breaking to introduce innovations and reforms (Mulgan 2006: 82). After all, breaking free from established structures and transcending disciplinary boundaries are two of the essential qualities of social entrepreneurs (Bornstein 2007). Doing so may be tantamount to social activism, not corporate citizenship per se, which business may ignore. However, this type of corporate citizenship programs may be viewed as another form of corporate charity. This, we argue, can be yet another future study, i.e., to delineate the boundaries of BbCC.

\section{Conclusion}

Land acquisition is a classic case where economic progress has come at the cost of various ethical disgraces. One of its damaging consequences is the proliferation of sustainability challenges arising out of socio-environmental injustices that dampen the prospects of sustainable business. However, there is no denying that the spirit of entrepreneurship is important for India's progress. One of the salient features of entrepreneurship is to capitalize upon opportunities. In this context, we argue that business and land-owners and users can leverage upon the opportunity of spontaneous land transfers to create positive socio-economic impacts by facilitating spontaneous transfers of land. $\mathrm{BbCC}-\mathrm{a}$ fusion between servant leadership and social entrepreneurship - is a generative attempt in this regard that can enhance the quality and magnitude of positive socio-economic impacts in the context of land acquisition. Considering its sustainability features, we argue that $\mathrm{BbCC}$ is a means through which business can serve and empower the imperceptible stakeholders, namely land-owners and users in the context of land acquisition, which can create social and environmental justice, triple bottomline outcomes, and sustainable and inclusive development of India

\section{Bibliography}

Ahmed S, Varshney A (2012) Battles half won: Political economy of India's growth and economic policy since independence. In Ghate $\mathrm{C}(\mathrm{Ed})$ The Oxford handbook of the Indian economy, 56-102. New York: Oxford University Press. 
Amnesty International (2016) "When land is lost, do we eat coal?" Coal mining and the violations of Adivasi rights in India. Retrieved from https://bit.ly/2b7Hsga.

Baggett B (1997) Power Serve: 236 inspiring ideas on servant leadership. Germantown, TN: Saltillo Press.

Bandyopadhyay D (2008 March) Does Land Still Matter? Economic \& Political Weekly (8): 37-42.

Bardhan P (2011) Industrialization and the land acquisition conundrum. Development Outreach 13: 54-57.

Barry B (1973) John Rawls and the priority of liberty. Philosophy \& Public Affairs 2: 274-290.

Beauchamp T (1980) Distributive Justice and the Difference Principle. In Blocker HG, Smith EH (Eds) John Rawls's theory of social justice, 132-61. Athens, OH: Ohio University Press.

Bennis W, Nanus B (1997) Leaders: Strategies for taking charge. New York, NY: HarperCollins.

Berlin I (1969) Four essays on liberty. Oxford, UK: Oxford University Press.

Bhagwati JN, Panagariya A (2013) Why growth matters: How economic growth in India reduced poverty and the lessons for other developing countries. New York: Public Affairs.

Bharathi KS (1991) The social philosophy of Mahatma Gandhi. New Delhi, India: Concept Publishing.

Bhave AV (2009) Bhoodan Yagna. In Desai AR (Ed) Rural sociology in India, 629632 ( $5^{\text {th }}$ ed.). Mumbai, India: Popular Prakashan.

Boehm A (2002) Corporate Social Responsibility: A Complementary Perspective of Community and Corporate Leaders. Business and Society Review 107: 171-194.

Bornstein D (2007) How to change the world: Social entrepreneurs and the power of new ideas. New York, NY: Oxford University Press.

Brass PR (1994) The politics of India since independence, $2^{\text {nd }}$ ed. Cambridge, UK: Cambridge University Press.

Brown DM (1961) The nationalist movement: Indian political thought from Ranade to Bhave. Berkley, CA: University of California Press.

Brown J (2000) Nehru. Hoboken, NJ: Pearson Education.

Business Standard (2013) Once landowners, they now work as security guards. Retrieved from https://bit.ly/2Nm4de8.

Chakravorty S (2013) The price of land: Acquisition, conflict, consequence. New Delhi, India: Oxford University Press.

Chakravorty S (2016) Land acquisition in India: The political-economy of changing the law. Area Development and Policy 1: 48-62.

Chandra B, Mukherjee M, Mukherjee A (2008) India since independence, Revised ed. New Delhi, India: Penguin Books.

Church R (1975) Review: The Impact of Bhoodan and Gramdan on Village India. Pacific Affairs, 48: 94-98.

Clark M (2009) The social entrepreneur revolution: Doing good by making money, making money by doing good. London: Marshall Cavendish.

Collier D (1995) Translating quantitative methods for qualitative researchers: The case of selection bias. American Political Science Review 89: 461-466.

Covey SR (1996) Three roles of the leader in the new paradigm. In Hesselbein F, Goldsmith M, Beckhard R (Eds.) The leader of the future: New visions, strategies, and practices for the next era, 149-159. San Francisco, CA: Jossey-Bass.

Crane A, Matten D, Moon J (2008) Corporations and citizenship. Cambridge, UK: Cambridge University Press. 
Dees JG (1998) The Meaning of "Social Entrepreneurship." Retrieved from https://stan ford.io/2QusxMJ.

Dees JG, Emerson J, Economy P (2002) Editors' introduction. In Dees JG, Emerson J, Economy P (Eds.) Strategic tools for social entrepreneurs: Enhancing the performance of your enterprising non-profit, xxix-xxxvi. New York, NY: John Wiley.

Dias A (2009) Eminent domain, displacement and impoverishment. In Modi R (Ed) Beyond relocation: The imperative of sustainable resettlement, 183-198. New Delhi, India: Sage.

Drayton R (2000) Nature's Government: Science, imperial Britain, and the 'improvement' of the world. New Haven, CT: Yale University Press.

Drèze J, Sen A (2013) An uncertain glory: India and its contradictions. Princeton, NJ: Princeton University Press.

Dutta Mishra A, Narayanasamy S (2009) World crisis and the Gandhian way. New Delhi, India: Concept Publishing.

The Economic Times (2015) Land acquisition a difficult task in India: Arvind Panagariya. Retrieved from https://bit.ly/2E1Dc0e.

Economy P (2002) Leading, retaining, and rewarding people entrepreneurially. In Dees JG, Emerson J, Economy P (Eds) Strategic tools for social entrepreneurs: Enhancing the performance of your enterprising non-profit, 71-92. New York, NY: John Wiley.

Ellis F (1993) Peasant economics: Farm households in agrarian development, $2^{\text {nd }}$ ed. Cambridge, UK: Cambridge University Press.

Feldman F (1996) Responsibility as a condition for desert. Mind, 105: 165-168.

Fernandes W (2004) Rehabilitation policy for the displaced. Economic and Political Weekly 39: 1191-1193.

Fernandes W (2008) Displacement and land alienation from common property resources. In Mehta L (Ed) Displaced by development: Confronting marginalization and gender injustice, 105-129. New Delhi, India: Sage Publications.

Figueroa M (1997) Bhave, Vinoba (1895-1982). In Powers RS (Ed) Protest, power, and change: An encyclopedia of nonviolent action from ACT-UP to women's suffrage, 43-44. London: Taylor \& Francis.

Ghatak M, Ghosh P (2011) The land acquisition bill: A critique and a proposal. Economic and Political Weekly XLVI: 65-72.

Goswami A (2016) Land acquisition, rehabilitation and resettlement: Law, politics and the elusive search for balance. Journal of Land and Rural Studies, 4: 3-22.

Goyder G (1961) The responsible company. Oxford, UK: Blackwell Publishing.

Greenleaf RK (2002[1977]) Servant leadership: A journey into the nature of legitimate power and greatness, $25^{\text {th }}$ Anniversary ed. Mahwah, NJ: Paulist Press.

Hardiman D (2003) Gandhi in his time and ours: The global legacy of his ideas. London: C. Hurst \& Co.

Hazra A (2006) Land reforms: Myths and realities. New Delhi, India: Concept Publishing.

Hickman GR (2010) Leading change in multiple contexts: Concepts and practices in organizational, community, political, social, and global change settings. Thousand Oaks, CA: Sage.

Hindu (2015) Private interest as public purpose. Retrieved from https://bit.ly/2yfdVJR.

Hindustant Times (2016) 'SC hiked relief in 6 out of 10 cases of land acquisition'. Retrieved from https://bit.ly/2E8tZ6q.

Howell MC, Prevenier W (2002) From reliable sources: An introduction to historical methods. New York: Cornell University Press. 
International Monetary Fund (2016) World economic outlook update: Uncertainty in the aftermath of the U.K. referendum. Retrieved from https://bit.ly/2aiakll.

Indian Express (2016) Land acquisition bill: Consensus eluded Centre, now four states relax their land laws. Retrieved from https://bit.ly/2xXb4Wz.

Jaffrelot C (2012). The political guru: The guru as éminence grise. In Copeman J, Ikegame A (Eds) The Guru in South Asia: New interdisciplinary perspectives, 80-96. New York, NY: Routledge.

Jayapalan N (2003) Indian political thinkers: Modern Indian political thought. New Delhi, India: Atlantic Publishers and Distributors.

Kell G, Levin D (2003) The Global Compact network: An historic experiment in learning and action. Business and society Review 108: 151-181.

Kitzi J (2002) Managing your board entrepreneurially. In Dees JG, Emerson J, Economy P (Eds) Strategic tools for social entrepreneurs: Enhancing the performance of your enterprising non-profit, 93-116. New York, NY: John Wiley.

Kornblum W (2012) Sociology in a changing world. Belmont, CA: Wadsworth Cengage Learning.

Korten DC (1984) Strategic Organization for People-Centered Development. Public Administration Review 44: 341-352.

Kotter JP (1996) Leading change. Boston, MA: Harvard Business School Press.

Kouzes JM, Posner BZ (1995) The leadership challenge. San Francisco, CA: Jossey-Bass.

Levien M (2011) Special economic zones and accumulation by dispossession in India. Journal of Agrarian Change 11: 454-483.

Linton E (1972) Fragments of a vision: A journey through India's Gramdan villages. Varanasi, India: Sarva Seva Sangh Prakashan.

Lobo L, Kumar S (2009) Land acquisition, displacement and resettlement in Gujarat: 1947-2004. New Delhi, India: Sage.

Logsdon JM, Wood DJ (2002) Business citizenship: From domestic to global level of analysis. Business Ethics Quarterly 12: 155-87.

Mandle J (2009) Rawls's a theory of justice: An introduction. New York, NY: Cambridge University Press.

Martin JS, Novicevic M (2010) Social entrepreneurship among Kenyan farmers: A case example of acculturation challenges and program success. International Journal of Intercultural Relations 34: 382-392.

Martin MM (1998) Trust leadership. The Journal of Leadership Studies 5: 41-49.

McKay J (1976) The coalescence of history and archaeology. Historical Archaeology 10: 93-98.

Meehan B (2004) 15 Minutes with Bill Drayton, CEO of Ashoka. Stanford Social Innovation Review 1: 11-12.

Melkote SR, Steeves HL (2001) Communication for development in the third world: Theory and practice for empowerment. Thousand Oaks, CA: Sage.

Michael A, Baumann MM (2016) India and the dialectics of domestic and international "land grabbing": Historical perspectives, current debates, and the case of Ethiopia. India Review 15: 112-135.

Mingers J, Standing C (2017) Why things happen - Developing the critical realist view of causal mechanisms. Information and Organization 27: 171-189.

Mulgan G (2006) Cultivating the other invisible hand of social entrepreneurship: Comparative advantage, public policy, and future research priorities. In Nicholls A (Ed) Social entrepreneurship: New models of sustainable Social Change, 74-95. Oxford, UK: Oxford University Press.

Munshi D, Kurian P (2007) The case of the subaltern public: A postcolonial investigation of corporation social responsibility's (o) missions. In May S, Cheney G, Roper J 
(Eds) The debate over corporate social responsibility, 438-447. New York: Oxford University Press.

Nanekar KR, Khandewale SV (1973) Bhoodan and the landless. Bombay, India: Popular Prakashan.

Narain V (2009) Growing city, shrinking hinterland: Land acquisition, transition and conflict in peri-urban Gurgaon, India. Environment \& Urbanization 21: 501-512.

NCAS (2005) Advocacy update on land rights: Issue 18. New Delhi, India: National Centre for Advocacy Studies.

Nedumpara JJ (2004) Political economy and class contradictions: A study. New Delhi, India: Anmol Publications.

Nicholls A, Cho AH (2006) Social entrepreneurship: The structuration of a field. In Nicholls A (Ed) Social entrepreneurship: New models of sustainable social change, 99-118. Oxford, UK: Oxford University Press.

Nielsen KB (2015) Between peasant utopia and neoliberal dreams: Industrialisation and its discontents in emerging India. In Hansen A, Wethal U (Eds) Emerging economies and challenges to sustainability: Theories, strategies, local realities, 79-91. New York: Routledge.

NITI Aayog (n.d.) Land acquisition: Rationale and the way forward. Retrieved from https://bit.ly/2OGnyLE.

Nozick R (2013[1974]) Anarchy, state, and utopia. New York, NY: Basic Books.

Oommen TK (1972) Charisma, stability and change: An analysis of Bhoodan-Gramdan movement in India. New Delhi, India: Thompson Press.

Pirson M, von Kimakowitz E, Spitzeck H, Amann W, Khan S (2009) Introduction. In Spitzeck H, Pirson M, Amann W, Khan S, Kimakowitz E von, Humanism in Business, 1-12. New York, NY: Cambridge University Press.

Planning Commission of India (2014) Data-book compiled for use of planning commission. Retrieved from https://bit.ly/2CsiJ2N.

Planning Commission, Government of India (n.d.). Report of the Steering Committee on rapid poverty reduction and local area development for the eleventh five year plan (2007-2012). Retrieved from https://bit.ly/2Pf24m3.

Porwal V, Singh S (2011) Land acquisition and determination of land price: A critical appraisal of the existing and proposed normative framework as applied in Singrauli district, Madhya Pradesh. In Somayaji S, Talwar S (Eds) Development-induced displacement, rehabilitation and resettlement in India: Current issues and challenges, 61-74. New York: Routledge.

Rawls J (1999 [1971]) A theory of justice, Revised ed. Cambridge, MA: Harvard University Press.

Reuters (2016) Indian farmers at risk as states bypass land acquisition laws - activists. Retrieved from https://reut.rs/2QBqAOT.

Robbins SP, Judge TA (2013) Organizational behavior, 15 ${ }^{\text {th }}$ ed. Hoboken, NJ: Pearson/Prentice Hall.

Russel RF, Stone AG (2002) A review of servant leadership attributes: Developing a practical model. Leadership and Organization Development Journal 23: 145-157.

Sabin M (2002) Dissenters and mavericks: Writings about India in English, 1765-2000. New York, NY: Oxford University Press.

Sahoo P, Nataraj G, Dash RK (2014) Foreign direct investment in South Asia: Policy, impact, determinants and challenges. New Delhi: Springer.

Sarkar A (2012) Development, displacement, and food security: Land acquisition in India. In Ghate C (Ed), The Oxford handbook of the Indian economy, 311-340. New York: Oxford University Press. 
Schein EH (2010) Organizational culture and leadership, $4^{\text {th }}$ ed. San Francisco, CA: John Wiley.

Schwab K (2008) Global corporate citizenship: Working with governments and civil society. Foreign Affairs 87: 107-118.

Sethi SP (2002) Standards for corporate conduct in the international arena: Challenges and opportunities for multinational corporations. Business and Society Review 107: 2040.

Shepard M (1987) Gandhi today: The story of Mahatma Gandhi's successors. Santa Ana, CA: Seven Locks Press.

Sherman TC (2016) A Gandhian answer to the threat of communism? Sarvodaya and postcolonial nationalism in India. The Indian Economic and Social History Review 53: 249-270.

Singh R (2012) Inefficiency and abuse of compulsory land acquisition. Economic and Political Weekly 47: 46-53.

Singh SK (2009) Basic features of the Indian economy in 1947. In Chandhoke N, Priyadarshi P (Eds), Contemporary India: Economy, society, politics, 3-15. Noida, India: Dorling Kindersley (India).

Smith BN, Montagno RV, Kuzmenko TN (2004) Transformational and servant leadership: Content and contextual comparisons. Journal of Leadership \& Organizational Studies 10: 80-91.

Somayaji S, Talwar S (2011) Development-induced displacement, rehabilitation and resettlement in India: Current issues and challenges. In Somayaji S, Talwar S (Eds) Development-induced displacement, rehabilitation and resettlement in India: Current issues and challenges, 1-10. New York, NY: Routledge.

Sud M, VanSandt CV, Baugous AM (2009) Social Entrepreneurship: The Role of Institutions. Journal of Business Ethics 85: 201-216.

Supreme Court of India (2016) In the Supreme Court of India, Civil appellate jurisdiction: Civil appeal no.8438 of 2016 (Arising out of SLP (C) No.8463 of 2008). Retrieved from https://bit.ly/2y12rKm.

Tajfel H, Turner J (1979) An integrative theory of inter-group conflict. In Williams JA, Worchel S (Eds) The social psychology of inter-group relations, 33-47. Belmont, CA: Wadsworth

Tennyson H (1955) India's walking saint: The story of Vinoba Bhave. New York, NY: Doubleday.

The New York Times (2015) Indian opposition delays Modi's land-acquisition effort. Retrieved from https://nyti.ms/2OIBjtf.

The Times of India (2014) Crony capitalism a big threat to countries like India, RBI chief Raghuram Rajan says. Retrieved from https://bit.ly/1rhPDIi.

The World Bank (2015) GDP per capita (current US\$) Retrieved from https://bit.ly/1q AC44p.

Time (1953) India: A man on foot. Retrieved from https://ti.me/2NsY6ok.

Time (1956) India: Course of an ideal. Retrieved from https://ti.me/2PkBY1d.

Times of India (2017) HC quashes land acquisition proceedings for Diamond Park. Retrieved from https://bit.ly/2y6IdPo.

Ulrich D (1996) Credibility X capability. In F. Hesselbein, M. Goldsmith, \& R. Beckhard, The leader of the future: New visions, strategies, and practices for the next era, 209219. San Francisco, CA: Jossey-Bass.

Van Dierendonck D (2011) Servant leadership: A review and synthesis. Journal of Management 37: 1228-1261

Varshney A (1998) Democracy, development, and the countryside: Urban-rural struggles in India. Cambridge, UK: Cambridge University Press. 
Venkatasubbiah H (1961) Indian economy since independence. Bombay: Asia Publishing House.

Watanabe S (1972) Creative time. In Fraser JT, Haber FC, Muller GH (Eds) The study of time, 159-189. Berlin: Springer.

Weber T (2004) Gandhi as disciple and mentor. New York, NY: Cambridge University Press. 


\title{
Identity and Perception of Risk for Entrepreneurs: Lessons from an Industrially Less Developed State in India
}

\author{
By Debdatta Saha*
}

Identity matters for entrepreneurship in business environments marked by financial market imperfections. In the absence of formal finance, much of the economics literature on entrepreneurship focuses on the interplay of moral hazard and limited liability in explaining outcomes. However, this formulation of the problem bypasses a discussion of how entrepreneurial identity informs her perception of business prospects. While a recent branch of the literature has introduced the importance of social networks in enabling access to finance in developing countries, it does not address the issues an entrepreneur faces in developing an "identity" by belonging to a particular region or place. This paper addresses the aspect of location-based counterfactual thinking (CFT) in identity formation (which is created naturally by being a native member of a region) and its impact on the risk perception of entrepreneurs in the context of an industrially backward region. While the empirical results of the paper are drawn from a primary survey in the state of Bihar, India conducted in 2016 through snowball sampling for food processing industries, the results generalize to any context of entrepreneurial identity in the background of a low industrial base. Drawing insights from enterprise ecology, we find that (i) counterfactual thinking matters for risk perception and that (ii) both these variables change over the lifetime of entrepreneurship. We find that as the experience of the entrepreneur increases and she/he accesses more business networks/ associations, perception of risk is lowered. Alongside, the negative affect in counterfactual thinking (linked to a location-based identity) changes to positive affect with experience and exposure to business networks. The policy lesson from this exercise is that industrial policy initiatives must go beyond pecuniary incentives and pro-actively engaging in supporting entrepreneurial learning to strengthen investments and industrial outcomes in states like Bihar.

Keywords: counterfactual thinking, Entrepreneurial identity, entrepreneurial risk perception, industrial policy

\section{Introduction}

A large body of literature exists on entrepreneurship, starting with seminal work by Schumpeter (1934) continuing in the neo-classical mainstream with studies by Kihlstrom and Laffont (1979) and Baumol (1993), in the discipline of economics. Other disciplines, such as organizational ecology (for instance, Gartner 1985, Gartner et. al. 1994) and social psychology (such as McClelland 1965, McGrath and MacMillan 2000) have provided important inputs regarding entrepreneurial motivation and behavior. Recent advances in entrepreneurial research has incorporated the important question of entrepreneurial identity; for

\footnotetext{
*Assistant Professor, South Asian University, New Delhi, India.
} 
instance, Murnieks and Mosakowski (2007) which assumes an important dimension in industrial spaces with low business concentration and therefore, sparse business networks. Defining entrepreneurial identity as a set of beliefs "commonly" held by the population and internalized by the cognitive processes of the entrepreneur, the literature points out its relation to roles that are attached to this identity. In a sense, these roles assign meaning to the term entrepreneur. A comprehensive view of these roles comes from Shane and Venkataraman (2000), who interpret an entrepreneur as a person engaged in the discovery, examination and exploitation of opportunities.

We contend that roles are not sufficient in themselves to provide a meaningful interpretation of entrepreneurial identity. We argue for the incorporation of the spatial context in the definition of who is an entrepreneur. The reason for this extension of dimension of definition is motivated by our survey of entrepreneurial risk perception in the Indian state of Bihar, which has had a history of law and order problems resulting in flight of capital and a low industrial base at present. Despite Gartner's (1989) commentary that research in entrepreneurial identity is likely to yield less dividends than a direct quest of behavior, it is our contention (corroborated by Murnieks \& Mosakowski (2007)) that embedding the question of motivation and behavior in the particularities of locational understanding of entrepreneurial roles and therefore identity (ies) is a much more meaningful investigation into entrepreneurial motivation and behavioral outcomes.

The central research question we investigate in this paper is: how does the locational context influence entrepreneurial behavior reflected in her/his perceptions of risk? Our hypothesis is that locational conditions, particularly in extreme conditions such as the one we describe give shape to entrepreneurial identities through the cognitive process of counterfactual thinking (CFT) in the form of regrets about being captive to the region, particularly when business outcomes are bad. These counterfactual thoughts get reflected in risk perceptions. We find that regrets about being native to a region like Bihar is markedly present in novice entrepreneurs, whereas this counterfactual thinking reverses (entrepreneurs express a desire to do business in Bihar due to its input advantages in the industry of food processing) for experienced entrepreneurs ${ }^{1}$ who have multiple memberships in business associations. These points to the influence of business networks and their mitigating influence on entrepreneurial cognition.

Our contention is that the kind of location-based identity that we discuss arises due to the history of Bihar, which has experienced severe law and order problems. From the 1980s to 2006, the state experienced what is called "jungle raj" or the law of the jungle, with a cottage industry of kidnappings and threats to functional entrepreneurs in the state (Chakrabarti 2013, Mukherji and Mukherji 2012). We have interviewed the proprietor of a restaurant in a very busy part of the capital city, Patna, who was kidnapped twice and had to shift his family out of the state for survival. The easy kidnapping targets (middle-sized enterprises) exited the state leaving behind the very small (not lucrative targets for the kidnappers) or a few very large industrialists (who could buy their protection) resulting in an

\footnotetext{
${ }^{1}$ Prior experience comes mostly as traders in the business supply chain.
} 
industrial structure that is referred to in the academic literature as the "missing middle" problem, which we illustrate in our paper.

The lessons from Bihar serve as a good example for similarly placed states, particularly in terms of the role of industrial policy. Our paper provides a test for whether entrepreneurial risk perceptions respond to governmental actions such as the provision of subsidies, which is not present in our data. As perceptions feed into industry outcomes through the channel of entrepreneurial investment behavior with a time lag, this missing middle problem is likely to be strengthened over time unless entrepreneurial expectations change, so that expansion in capacity is made by small firms along with simultaneous entry of mid-sized firms into the industry. This can only happen with infrastructure encouraging better flows of information (business networks/ business associations) and with entrepreneurs with prior experience (particularly in trading or some other part of the supply chain) entering business. While these results are drawn from a primary survey in one particular industry (food processing) in Bihar, we believe that these results will be stronger for other industries, where Bihar does not have a clear input advantage. Unless entrepreneurial risk perceptions are reflective of positive counterfactual thinking (individuals opine that they would do business in the state even if they were not native to the state), future investments and capacity expansion is unlikely to follow even with government provision of pecuniary support.

The paper is structured as follows: we first present a brief survey of the literature on identity and cognition in entrepreneurship, while clearly underlining the contribution of the paper to the extant literature. We, then, delineate our empirical methodology and the development of empirically testable hypotheses. We follow up with descriptive statistics of the sample along with results regarding the hypotheses and a test for the representativeness of the sample. We provide some policy recommendations prior to the conclusion of the paper.

\section{Literature Review}

Most of the literature on entrepreneurship studies the discipline along the lines of individual entrepreneurial traits (innate ability) or through cognitive approaches to entrepreneurial decision-making (Sánchez et al. 2011). Another branch of entrepreneurship, which is relatively neglected and has limited number of papers and application, is entrepreneurial identity (Murnieks and Mosakowski 2007). These branches of the literature are somewhat independent of each other. The traits-based approach predefines the identity and associated roles of an entrepreneur and searches for individual traits that result in successful entrepreneurship. Despite its success in predicting outcomes, this approach sets rigid boundaries to who is or who is not an entrepreneur by placing central status to innate traits possessed by individuals. This does not address the process of how sometimes non-entrepreneurs or forced entrepreneurs (without innate ability) which is what we are interested in. Is it possible for a regional government to foster entrepreneurs in a region with very little entrepreneurship and low industrial base? 
If we explore the identity-based exploration of entrepreneurship, we find its exclusive engagement with the relationship between who an entrepreneur believes she/he is and her/his roles/actions to be performed in the conduct of business. Now, what forms the identity standard? A structural identity theory (Burke and Stets 2009) point out that identity is what is internalized by the entrepreneur as his/her role. In many situations, this internalized identity is a self-concept (not influenced by external influences), so that attitudes such as perception of risk and resultant investment behavior is left to the agent himself/herself (for instance, Gimeno et. al (1997) point out that entrepreneurs are motivated from within). There is no direct superimposition from social norms or network standards regarding this identity. The entrepreneur tries to live up to his or her own selfcreated standard.

Next comes to the issue of the constituents of identity: for instance, what is the content of identity? Is it unidimensional or multi-dimensional? Regarding content, there are multiple contenders in the literature. Cast (2004) claims "an identity is a set of meanings that represent the self in a social role, defining who one is in that status" (p. 57). Stryker and Serpe (2000) note that these are "reflexively applied cognitions that answer the question 'Who am I?" Regarding the content of entrepreneurial identity, Murnieks and Mosakowski (2007) note that there is relatively paucity of academic investigation. We contend that entrepreneurs develop their identities in two ways: one, by absorbing socially-held behavior expectations attached to positions. By definition, these are external to the individual and are assimilated into the entrepreneur's notion of self through a process of absorption (Gecas 1982). An example is the exploration of entrepreneurial identity resulting from an individual's socialization in the context of school peers shaping entrepreneurial intentions (Falck et al. (2012)). Second is a set of ideas held internally by the entrepreneur? For instance, Baum et al. (2001), Baum and Locke (2004), Chen et al. (2009), Cardon et al. (2009) as well as Murnieks et al. (2012) identify passion as a driving force in entrepreneurship, a factor that is innate to the entrepreneur and potentially empowers her/him to fight external resistance and problems in doing business. These identities, whether absorbed in from the external environment or part of the internal belief set of the entrepreneur, are multidimensional entities and display stability as well as individual peculiarities, due to differential absorption of concepts or variation in internal notions of identity (McCall and Simmons 1978).

The obvious question that arises is about the relationship of entrepreneurial identity with the third approach to entrepreneurship that is cognitive in nature. Irrational factors such as heuristics and reasoning fallacies such as planning errors (Baron and Markman 1999), overconfidence (Russo and Schoemaker 1992, Kahneman and Tversky 1973); over-optimism (Dawson and Henley 2013)) and counterfactual thinking (Hmieleski and Corbett 2008, Markman et al. 2005, Zhao et al. 2005) are a part of this branch of the literature. Its pro-active concern about the actual decision-making process rather than innate traits that lead to successful entrepreneurship sets this branch of the literature apart (Sánchez et al. 2011). And yet, very few papers have clearly pointed out the link between the identity based and the cognitive approach to entrepreneurship, which is critical for the context 
that we are interested in whereby ordinary individuals become active entrepreneurs in difficult business environments.

One exception in the entrepreneurship identity literature is Burke (2004). By likening the process of entrepreneurship to control systems, he forcefully links identity with counterfactual thinking (CFT). He defines the process of entrepreneurial identity as: "A cyclical process occurs when an individual takes some action, views that action, evaluates the results in comparison with the standards embodied within an identity, and then incorporates this new information to modify his or her behavior to improve the expected results." Behavior is continually altered until feedback matches the identity standard (Burke 1991a). A perfect match results in self-verification leading to a variety of emotions (ranging from satisfaction to elation) depending upon the context. When the match fails to take place, self-verification fails leading to cognitive dissonance and varying levels of distress (Burke 1991b). The in-built identity(ies) then motivate behavior modification until feedback matches identity standards, so that the individual can avoid distress associated with the lack of self-verification and enjoy the positive outcomes where self-verification is achieved (Burke 1991b).

However, an important aspect of the identity creation process is that it is understood by its relation to other identities, which it does not encompass (Burke 1980). As Murnieks and Mosakowski (2007) point out, the identity of "wife" gets defined associationally with that of "husband". Hence, an entrepreneurial identity rests heavily on how the person defining it views non-entrepreneurial identities. This has special importance in the context of such identities in geographical areas with low industrial bases, where the firm finds its operations limited by local market size, has limited exposure to external markets and has very sparse business networks to interact with. Entrepreneurship here gets tightly associated with the regional context within which the business is confined (here we assume that there are not many export and trade linkages with rest of the world, which is the case for the case we study). Essentially, in the case of Bihar, and entrepreneur considers that he is not only engaged in doing business, but also that she/he is "doing business in Bihar". This link of regional identity and CFT has not been pointed out by either the cognitive or the identity aspects of the entrepreneurship literature.

How does this regional/local contextualization matter in defining identity? Our paper shows that this aspect of local identity shows up in a particular kind of cognitive CFT, particularly in regions with poor industrial infrastructure and outcomes. To build this context, we borrow the definition of entrepreneurial identity from Haynie et al. (2009), who define entrepreneurship as a process of envisioning the future. This process necessarily entails CFT of the kind "what might have been had different actions been undertaken or had circumstances been different".

However, CFT is a broad collection of cognitions that an entrepreneur engages in situations of stress, as pointed out earlier (Baron 2000, Markman et al. 2005). CFT is in a sense a display of cognitive dissonance and allows the entrepreneur to explain away unpalatable outcomes and situations to themselves in order to move ahead (Wadeson 2006). There are many kinds of CFT and it is therefore unsurprising that the empirical evidence about entrepreneurial CFT is not 
conclusive. While some researchers (Baron 2008, 2000) show that entrepreneurs do not engage in as much CFT as non-entrepreneurs, Gaglio and Katz (2001) and Gaglio (2004) in fact show that entrepreneurs have very complex thinking processes and engage in significant CFT. It is at this point in the literature that we start working by picking up a very precisely defined type of CFT, which is linked to an entrepreneur's regional identity and show its effect on behavior which we again define narrowly as entrepreneurial risk perception, which papers such as Sitkin and Pablo (1992) and Sitkin and Weingart (1995) show are crucial in risktaking behavior of entrepreneurs.

\section{Contribution to the Literature}

Our contribution to the literature on entrepreneurship is two-fold. First, we provide a linkage between the identity and cognitive approaches to entrepreneurship by explicitly demonstrating the existence of a locational-identity based counterfactual thinking (CFT) that entrepreneurs engage in. CFT collects all varieties of coping mechanisms that are a part of the cognitive process of entrepreneurial decision-making. We model a particular category of CFT that derives its expression from the regional identity of the entrepreneur in the form of "had I not belonged to this region, I would not have done business here" thus relieving some of the cognitive distress due to non-performance. Whereas the identity literature has exclusively focused on the question of who the entrepreneur thinks she/he is in relation to her/his roles, we extend the identity issue into the cognitive process as reflected through CFT.

Second, the literature on CFT presents ambiguous results, with one branch clearly pointing to lack of CFT among entrepreneurs (Baron 2008, 2000) relative to non-entrepreneurs and another pointing to the presence of complicated CFT among entrepreneurs (for instance, Gaglio and Katz (2001)). We resolve this paradox partially by pointing out that rather than a quantitative absence or presence of CFT, our data reveals that the quality of this kind of cognition changes over the life-cycle of entrepreneurs. We find relatively novice entrepreneurs answer the question "would you have done business in Bihar had you not been native to the state" with a strong negative answer, experienced entrepreneurs in fact respond with a positive response (they would do business in the state of Bihar even if they were not native to the state). That experience matures an entrepreneur and changes the nature of cognition of the entrepreneur is also captured through a lower perception of risk for experienced entrepreneurs. Locational-identity based CFT is positively correlated with the cognitive perception of risk in our data. Further, we point out the channel which has the potential to mitigate the negative affect related to uncertain business outcomes. It is not policy variables such as government subsidy or business specific factors such as line of business, land size, access to institutional finance or inherited factors such as father's profession. We find membership in business associations, which are symbolic of the ties to business networks (Munshi 2010) is positively correlated with risk perceptions and hence CFT. Our argument runs along the following lines: Given that industrial outcomes have been stymied for a long period of time and that many businesses 
have not been able to expand in Bihar, a novice expresses her/his frustration of low business outcomes by ascribing the blame to being tied to the immediate context of Bihar rather than personal non-performance. As an entrepreneur gains experience despite being constrained to operate in the same region with low industrial achievements, his CFT changes from negative to positive and risk perception goes down. This is exhibited by the behavior of becoming members of more business associations. Potentially, entrepreneurial identity starts out as a selfconcept for a novice and over time assumes an identity mitigated by social norms and expectations, such that a non-entrepreneur (with negative locational-identity based CFT and risk perception) becomes an entrepreneur with experience with access to many business networks (with positive locational identity-based CFT and risk perception). We find Podoynitsyna et al. (2012) have explored the same issue from the dimension of mixed emotions in cognitive appraisal (we explore this through CFT). Their research also concludes that negative affect emotions change to positive ones along with changing risk perception as an entrepreneur gains experience. We surmise that it is incorrect to conclude either that entrepreneurs systematically disengage with CFT or otherwise. This cognitive process varies over the life-cycle of entrepreneurship, leaving clear implications for industrial policy that we discuss later in the paper.

\section{Methodology}

\section{Research Design}

We derive our estimates of CFT and risk perception through an empirical exercise using a primary survey among formal registered units (partnerships as well as limited liability companies for a total of 76 units) in Bihar in 2016-17 as part of an IGC-funded project "Study of the Food Processing Sector in Bihar". There is no published literature attempting this exercise for Bihar and there are many difficulties in contacting individual entrepreneurs through surveys (for instance Munshi (2010) details the difficulties of surveying entrepreneurs in the diamond trading and polishing industry).

We selected the food processing industries for conducting our survey, as Bihar has a natural input advantage in terms of agricultural raw materials ${ }^{2}$. Our choice of industry was corroborated in the survey, where entrepreneurs uniformly identified the input advantage of Bihar for food processing. Our sampling method is based on snowball sampling, as discussed in Noy (2008) and Newman (2018). This sampling technique is non-randomized and appropriate when the population is not known with certainty (for example, for hidden samples and networks). It is impossible to note at a point in time the total number of functional units unless the scale of the survey is very large, such as the ASI (Annual Survey of Industries). Given continuous entry and exit, exact data on the population of functional units is a rough estimate. The primary reason is that there is no legal restriction on an

${ }^{2}$ Successive Economic Surveys of the State of Bihar reveal the comparative sectoral advantage of food processing due to abundance of agricultural raw material available in the state. 
exiting firm to inform any authority that it is leaving business in any state in India. Lack of an industrial exit policy has exacerbated this problem. This problem apart, we found in our initial interactions with one of the prominent business association in the state (Bihar Industries Association (BIA)) that no individual entrepreneur would be forthcoming in their interviews unless given a proper reference for the surveyor, similar to the problems mentioned in Munshi (2010). While the diamond industry is by nature secretive, we presume it is the problematic history of the state in terms of law and order as discussed earlier that leads to reluctance on the part of the entrepreneur to reveal attitudes and business practices unless certified through proper agency.

With permission of the state government of Bihar, the Program Management Agencies (PMAs) ${ }^{3}$ and the BIA, we snowballed our sample from an initial source (with the BIA) and increased our sample size through referrals to friends and associates, ensuring a decent sample size across various sub-sectors of food processing. Our method also helped us identify some recently exited enterprises to include in our sample thus ensuring heterogeneity in units' operational status. The disadvantage, of course, is that it would be difficult to gauge population estimates from our sample. However, given that we have ensured the Fisherian principle ${ }^{4}$ of heterogeneity in samples, we believe that our sample estimates are close to the population estimates. In fact, we show that the missing middle size that is present in our sample is present in the population as well, which gives us confidence that our sample is representative of the population.

We conducted a mixture of telephonic and face-to-face interviews of entrepreneurs mostly from several districts in Bihar (such as Muzaffarpur, Patna, Gaya, Nalanda and Hajipur etc.). Two of the units surveyed resulted in managerial interviews and not that of the original entrepreneurs and hence were not included in the final sample for understanding perception of risk.

Our interest was to study the indigenous firms of Bihar, our strategy was to interview firms with production facilities in the state and not simply marketing their products, Given the large domestic consumption market, initial discussion with the business associations indicated that this risk is not as large as the risk of starting a business for established units. Of course, many small units have also indicated that marketing their product is a challenge in the local market. As we want to correlate the total risk of doing business with incentive policies for manufacturing, we have selected only those units which are engaged not only in marketing but also have production facilities within the state. Another related caveat is that the food processing industry has a long supply chain that extends from production to services. We have ignored the latter set of enterprises (such as restaurants serving processed food) from our sample, as risks involved in the physical production supply chain is very different from those in services (for instance, the World Bank Enterprise Survey uses different survey instruments to

\footnotetext{
${ }^{3}$ These agencies have been instituted by the state government for professional management of investment projects, particularly for helping the entrepreneur arrange necessary documentation and other proof for application for subsidies from the government.

${ }^{4}$ Fisher RA (1939) Student. Annals of Eugenics 9(1): 1-9.
} 
sample enterprises across different countries mentioning this issue of differential business structures in services and manufacturing).

\section{Defining Risk Perception and CFT in Entrepreneurial Identity}

As investment behavior and industrial outcomes are driven by perception of risk, rather than objectively measured risk, we focus on the variable of perceived risk. As mentioned earlier, we define the perception of risk in doing business as combination of production, marketing and security of property challenges that adversely affect profits. We do not segregate between different types of business risk, rather the total risk in operations (as a combination of production, marketing and protection of investment). We measure risk perception through two instruments:

(i) as a single variable that adversely affects profits of the enterprise: we measure this in two ways: one, as a direct scale measure of risk perception and second as a categorical variable with two categories (low risk and high risk). The first is a scale measure of perception of total risk for an entrepreneur. It is measured on a scale of zero to five, with zero reflecting very high-risk perception and 5 reflecting minimal risk perception. The categories 1 and 2 reflect high risk perception (value less than or equal to the average of 2.5) and low risk perception (value greater than 2.5) respectively. The cut-off of 2.5 is based on the mean value from $\mathrm{N}=72$ valid responses for this question. We refer to this categorized measure as the "risk code".

(ii)through a location-specific counterfactual: as a Bihar-specific issue that would not be present, had the entrepreneur been operating in another state. We asked the entrepreneur whether he/she would do business in Bihar had he/she not originated from Bihar and was an outsider. This second measure is intended to understand how much of a pure input advantage in food processing that an entrepreneur perceives, to the extent that he/she would find it profitable to enter Bihar to set up operations even if his origins were outside Bihar. This measure (we term it counterfactual) is categorical, the categories being "yes" (entrepreneur would do business in Bihar even if from outside Bihar), "no" (entrepreneur would not do business in Bihar if a native of the state) and "uncertain" (entrepreneur is uncertain about his/her choice). This measure captures CFT present in entrepreneurial identity arising from a location-specific factor.

Given the history of problematic governance in Bihar prior to 2006, we feel the second issue is very important as it reflects on the safety of investments, a primary driver of ease of doing business expectations and gains importance for deriving appropriate industrial policy implications. 


\section{Development of Empirically Testable Hypotheses}

There are two ways to understand outcomes in the food processing sector from a micro-agency perspective. Ceteris paribus the institutional and unobservables, outcomes can be observed from the functional efficiency of the enterprise as well as from an individualistic entrepreneurial ability perspective. The latter, though more of a socio-anthropocentric study of entrepreneurship, matters a lot when the industrial bases as well as institutions for industrialization are low and weakly developed as is the case for Bihar. The former approach, which can be understood from an efficiency analysis (in the sense of output per unit of input provided), is more along the lines of traditional economic analysis.

The other measure more reflective of entrepreneurial ability is experience of the entrepreneur, where experience is meant to capture exposure to all activity (such as trading) related to business prior and during the period of enterprise activity as revealed during the interview. This variable can take a value higher than the age of the unit given our definition of experience.

The importance of experience in enabling entrepreneurship is becoming increasingly clear in the literature, particularly trading experience such as Munshi (2010). Trading creates a human capital in the form of knowledge of supply chains as well as a clear understanding of the nature of the business as well as consumer mindsets apart from creating the necessary wealth for moving on to the next stage of business: entrepreneurship, where the trader becomes an independent operator thereby becoming the residual claimant of risk, which she/he could avoid through fixed payment trading contracts.

In our study, we test for both; whether prior experience correlates to entrepreneurial aspirations (which are also indicative of the wealth-creation potential of trading activity) as well as informational advantages of experience which should be reflected in risk perceptions. The former is more along the lines of existing literature, whereas the latter is our addition to understanding the genesis of entrepreneurship through the lens of perception of risk.

Both these aspects of entrepreneurial functioning (efficiency of operations and outlook of business risk) are likely to be a function of whether entry into business is due to self-interest or due to existing family concerns. Inheriting land and business operations reduces the burden of starting a new business. However, familial involvement through financial or managerial participation is indicative of informality of operations, without the involvement of management professionals hired from outside the family to incorporate best business practices into daily operations.

Interestingly, though 17 entrepreneurs note the latter as the reason for business entry, continuous engagement of family members in various aspects of enterprise operations have been mentioned by almost all the remaining 59 entrepreneurs. None of the units are listed on stock exchanges and a few began as limited liability partnerships (LLPs) ${ }^{5}$, with equity participation from various family members. Majority of these operations involve family members in

${ }^{5}$ Five units continue to be LLPs. 
managerial positions and the distinction between profits earned from the business and personal income is blurred and fungible ${ }^{6}$.

In terms of methodological approach towards understanding drivers of entrepreneurial perceptions, we abandon the efficiency-based approach such as Stochastic Frontier Approach (SFA) or Data Envelopment Analysis (DEA) in preference for a direct description of risk perceptions and their potential contributors. The primary reason for not adopting an SFA or a DEA technique for capturing efficiency at the level of the food processing sector level (encompassing the six selected sub-sectors) is that this methodology is not amenable to multiple sub-sectoral pooling of units. Efficiency drivers for rice milling (dependent on technology employed therein) vary significantly from that for cold storages. Hence, there is no meaningful way to capture the overall efficiency of units in food processing. If we restrict ourselves to the sub-sectoral level, either SFA or DEA will not be very robust as some sub-sectors have very few observations (such as four units for dairy).

Given our research objective, our testable hypotheses are:

H0. Entrepreneurial identity generated by domicile state of the entrepreneur (measured through a location-specific counterfactual) is reflected in her/his risk perception.

This test corroborates that our scale measure of risk perception (also captured through the two categories of risk code) captures the same concept as captured by the counterfactual. If we establish this hypothesis through our data, we can claim that CFT in entrepreneurial identity is captured through their perception of risk in industrial contexts similar to Bihar.

H1. Risk perception and CFT is not constant for different cohorts of entrepreneurs.

H1a. (Business Specific Linkage) Risk perception (and CFT) is a function of the specific sub-sector in which the entrepreneur operates.

H1b. (Resource Specific Linkage) Risk perception (and CFT) varies according to enterprise size, land holding and access to finance.

H1c. (Policy Linkage) Risk perception (and CFT) varies according to government subsidy.

H1d. (Attribute Specific Linkage) Risk perception (and CFT) varies according to father's occupation or entrepreneurial experience.

The purpose of this hypothesis is to reconcile the two contrasting results in the cognitive literature on entrepreneurship, one of which claims that entrepreneurs do not engage in significant counterfactual thinking as compared to a nonentrepreneur whereas the other claims significant CFT among entrepreneurs. We check for differential CFT among different types of entrepreneurs, where the segregated classes are based on either business-specific reason (sub-sectoral

${ }^{6}$ Informality in operations is evident as the accounting of books is done by the entrepreneur herself/himself as she/he is a Chartered Accountant (as was the case with at least three units). 
specificities of operations resulting in differential technological and business cycle risks), resource-specific conditions such as enterprise size, land and access to finance, policy conditionings measured by access to government subsidy or entrepreneurial attribute specific linkage such as gender, family influence (measured by father's occupation) and experience.

\section{Results and Discussion}

\section{Sample Description}

The distribution of units in our sample is shown in Table 1.

Table 1. Distribution of Various Units in Primary Survey for Food Processing in Bihar

\begin{tabular}{|l|c|}
\hline Enterprise Type & Number of units sampled \\
\hline Cattle/Poultry Feed (maize-based) & 9 \\
\hline Cold Storage & 15 \\
\hline Rice Mills & 19 \\
\hline Honey-based & 8 \\
\hline Dairy & 4 \\
\hline Others & 21 \\
\hline Total & 76 \\
\hline
\end{tabular}

Source: Author.

To capture functional diversity and explore efficiency of units, we include in our sample not only mature units across sub-sectors, but non-functional units (closed as well as yet-to-start-operations) in our sample. We also have a variation in terms of maturity (units less than one year old we term nascent and more than one year as mature). Not only does this help us avoid survival bias in our sample, it also helps us correlate outcomes with risk perception, which was our primary objective for conducting the survey. Of the total 76 units, the majority 61 are functional and mature units, whereas 8 units are nascent (less than a year old), 2 units are in a planning stage (production yet to begin) and 5 units are nonfunctional and in various stages of exit.

Note that none of these businesses are exporters and their marketing is limited to consumers within the state of Bihar.

\section{Variable Description}

Size of Enterprise: Note that around 60 per cent of the sample report an initial cost (including land, machinery and plant) less than 0.7 million USD in current prices (characterized as small units by the Ministry of Micro, Small \& Medium Enterprises, Government of India). The remaining 40 per cent of the sample have project sizes less than 7 million USD in current prices. Only two functional units (both in dairy processing) have a project size of 17 million USD in current prices. The pattern of many small and few large comes out 
through other measures as well, such as land size (majority with less than one acre of land and a minuscule with over 50 acres). While this comforts us that our sampling strategy (though non-random and conducted with the specific purpose of identifying networks of entrepreneurs) does reflect the pattern in secondary data, this is anything but the picture of a healthy industrial scenario.

Education and Age: Our data has significant variation built in for parameters such as age and education. The average age of the entrepreneur in our sample is 45.4 years, with a large age variation from 21 to 72 years. The lowest education qualification is a Class X (4 individuals) ranging right up to doctoral degrees (3 entrepreneurs) and professional qualifications such as Chartered Accountancy (1 observation) and MBA from universities in India and the UK (total 10).

Entrepreneur Origin: However, there is much lower variation for origin of the entrepreneur. We define an indigenous entrepreneur as one whose last three generations have been in Bihar. Sixty four of the 76 sample points are indigenous entrepreneurs. Being in the local conditions matter, as majority interviewed mentioned that they are doing business in Bihar because "they are from Bihar" and in fact, as our later observations show, display skepticism as to whether they would do business had they been outsiders.

Women Entrepreneurship: Similarly, we have very few women entrepreneurs (only eight women with relatively small projects (other than a wheat milling plant)). Low female entrepreneurship, despite special incentives in successive industrial policies of the state, is reflective of the overall low human capital outcomes (education, skilling, work force participation). For most of the women interviewed, their entrepreneurial income is seen as an additional input to total family income and not an essential component of financial buoyancy of their families. This possibly translates to lower risk perceptions among women in our sample, as they have an easier outside option.

Main Cost Component: The main cost component for the enterprises was the fixed cost of plant, machinery and civil works (for more than fifty per cent of the sample) followed by the running cost of electricity. Only six enterprises mentioned the fixed cost of land as the most important component of setting up business operations. While there is some sub-sectoral pattern in the cost component (cold storages mention electricity as the main source of expenditure, whereas some rice mills consider the variable cost of paddy input as the highest cost component), the pattern is to be understood with the age of the unit, as many of the older establishments have already amortized their fixed costs, and are more concerned about variable costs of operations.

Father's Occupation: Exposure to business activities through father's profession helps in forming attitude to business prospects and risks. In our sample, there is some variation regarding this, with 27 entrepreneurs reporting that their fathers were either in same/unrelated business or involved in trading activities and 16 others mentioning that their fathers were either farmers owning land or zamindars (landowners). The remaining 33 entrepreneurs report diverse professions for their fathers (ranging from professors to government employees to mukhiya) mostly in the service sector. It is interesting to note that though the 
majority of the sample mention self-interest as the reason for doing business, majority of the father's profession was unrelated to business.

Type and size of land: Related to the earlier variable is ownership of land or rather, the type of land on which the unit is established. Half the samples have put up their manufacturing on their own land, which they have leased to the unit. Among the remaining 38, the majority of 28 have leased land from the BIADA (Bihar Industrial Area Development Authority). Given the increasing circle rates due to pressure from the demand side, the latter option has become extremely expensive. According to some of the older establishments, setting up operations on BIADA land with current lease rates would make operations financially unviable.

Land size is a difficult variable, which reflects the problem of the extreme distribution of project sizes in the sample (as is the case with the population of firms in Bihar, as pointed out in the previous chapter). The mean size holding is 27.88 acres, which is small by industrial standards in India. However, the standard deviation of 199.04 is much larger than the mean and is resonant of the large variation in unit sizes.

Membership in Associations: Exactly half the samples do not have any membership with any of the business associations within the state, such as the Bihar Chamber of Commerce or the Bihar Industries Association. Nonetheless, they do have contacts with members of such associations, who referred them to us (due to our sampling strategy). Only six members have multiple memberships (these are old established units). As these associations, which have a representation with the government, are located in Patna, units in the distant districts do not find membership with these associations improving their lobbying power or information sources. Most of the consumption markets (for the small units) are concentrated in the local regions and are not even an all-Bihar presence; hence it is rational not to invest in these memberships.

Experience: We capture prior experience as traders before each entrepreneur in our sample. With 15 missing observations, the minimum and maximum years of experience is zero and forty-six respectively, with a mean of 13.26 years and a relatively large standard deviation of 10.79 years.

Marketing: Other than for cold storages, almost all units market their own products under their own brand names. Almost all cold storages in Bihar operate on a rental model, where the owner lets farmers store their produce in the cold storage against a rental. Most of these sell the final produce as a part of business policy; only when they are forced to when the farmer refuses to collect the stored product at the going rental due to price reductions in the market. Few exceptions are in Nalanda, where the cold storages store flowers which they sell to tourists and in Hajipur, where the owner sells unbranded apples in cartons to buyers in Delhi. However, in terms of using modern retail marketing channels such as online platforms, only two entrepreneurs mentioned that they are considering these options to diversify marketing risks.

Business Outlook (Strengths and Challenges): We asked the entrepreneurs to identify the top two factors that are the strengths and challenges for the subsector that they are functioning in. We asked this question in terms of overall macro variables which affect all units, and not their own business operations 
alone. This helps us capture what an individual entrepreneur perceives is the overall challenge as well as advantage of doing business in their line of activity. This variable helps us capture shared vision and goals at the subsectoral level among entrepreneurs.

Interestingly, there is no uniformity in business outlook in terms of challenges, even within our small sample. Among the important problems are: corruption and law and order, availability of land, inadequate infrastructure (either absent or very poor Industrial Area, identified by entrepreneurs in districts further away from Patna/Hajipur), inadequate information and policy thrust and finance.

However, in terms of sub-sectoral strengths, there was uniformity in responses: abundant raw material resources, large local demand (low competition other than for rice mills) and no labor trouble. It is difficult to create an index from the responses, particularly for challenges, as some of the responses are unique and not shared by any other respondent (for instance, declining productivity of fruit yields (litchi) due to inadequate research and development).

\section{Test of Hypotheses}

At the outset, note that three entrepreneurs are multi-plant and multi-sector (one of them has three separate units), which we count as individual responses for our analysis, as we ensured during our interviews that the responses be catered to for each unit separately. However, for the risk perception variables, there is a duplication of observations (as we find no variation in these responses across units for an individual entrepreneur). We also have some non-responses for the counterfactual variable, so that the valid no. of observations $(\mathrm{N})$ for our study is 71. While it is understandable that the counterfactual variable is slightly harder to mentalize, we have remarkably consistent answers, showing that our two measures are indicative of risk perceptions.

H0. Entrepreneurial identity generated by domicile state of the entrepreneur (measured through a location-specific counterfactual) is reflected in her/his risk perception.

In order to test this hypothesis, we check whether responses with a high direct risk perception (low scale measure as explained later) also answer in the negative ("no") for the counterfactual. Results are reported in Table 2.

Table 2. Risk Code * Location-Specific Counterfactual (CFT) Crosstabulation

\begin{tabular}{|l|c|c|c|c|}
\hline \multirow{2}{*}{ Risk Code } & \multicolumn{4}{|c|}{ Location-Specific CFT } \\
\cline { 2 - 5 } & Uncertain & No & Yes & Total \\
\hline Risk Code 1 (High Risk) & 6 & 23 & 5 & 34 \\
\hline Risk Code 2 (Low Risk) & 4 & 17 & 16 & 37 \\
\hline Total & 10 & 40 & 21 & 71 \\
\hline
\end{tabular}

Source: Author. 
Table 2 shows the cross-tabulations of the categorized risk code against the counterfactual. While the total number of responses for a high direct risk perception (34) is marginally lower than that for low risk perception (37), there is a clear correlation in the number of entrepreneurs who mention that they would never do business in Bihar if they were not indigenous to the state and entrepreneurs with a high perception of risk. Twenty three of the 34 high risk entrepreneurs answer a "no" for the counterfactual, which is around 68 per cent of the total high risk entrepreneurs. The percentage of low risk entrepreneurs who answer "no" for the counterfactual is 46 (17 out of 37 low risk responses). On the other hand, 43 per cent (16 of 37) of the high risk entrepreneurs answer "yes" for the counterfactual, whereas only 15 per cent of the low risk entrepreneurs (5 out of 34) give an affirmative response.

This is a clear indication of the direction of risk responses: higher perception of risk is correlated positively with a negative impression of doing business in Bihar (independent of input advantages) and vice versa.

Hence, we confirm our hypothesis H0. (that counterfactual thinking is reflected in risk perceptions).

H1a. (Business Specific Linkage) Risk perception (and CFT) is a function of the specific sub-sector in which the entrepreneur operates.

We find no direct evidence of any sub-sectoral pattern with risk perception. It is not the case that rice millers display a significantly high perception of risk than cold storage or other units. Hence, for the purpose of the risk assessment, we club all units together and present our central results for the rest of the analysis. This also shows that H1a. is not valid in our data: risk perception is not driven by business specific linkages defined by the specificities of nature of business.

H1b. (Resource Specific Linkage) Risk perception (and CFT) varies according to enterprise size, land holding and access to formal finance.

Hlc. (Policy Linkage) Risk perception (and CFT) varies according to government subsidy.

In our data, neither loan size (access to formal finance) nor government subsidy show a statistically significant correlation with the risk perception (scale measure). Though size of land-holding (and hence size of the enterprise) is positively correlated with risk perception (scale measure), the Pearson correlation coefficient of 0.013 is not statistically significant. Therefore, we conclude that our data does not support H1b. or Hlc.

Hld. (Attribute Specific Linkage) Risk perception (and CFT) varies according to father's occupation or entrepreneurial experience.

We find experience matters for direct perception of risk. We reconvert to actual numbers (on the scale from 0 to five) for the direct risk perception measure, as experience is a continuous measure. We present in Table 3 results of the correlation between direct risk perception and experience. 
Table 3. Pearson Correlation Coefficient between Risk Perception and Experience

\begin{tabular}{|l|c|c|}
\hline & Risk Perception & Experience \\
\hline Risk Perception & 1.00 & \\
\hline Experience & $0.27^{*}$ & 1.00 \\
\hline$*$ indicates statistical significance at 0.05 level (2-tailed test) \\
\hline
\end{tabular}

Source: Author.

Experience is positively correlated with higher values of the risk perception scale measure, which translate to low risk perception and is along the lines of existing literature (Podoynitsyna, Bij \& Song (2012) and Munshi (2010)).

Investigating the manner in which experience matters for risk perceptions, we control for whether the entrepreneur belongs to a business family (and therefore perceptions of risk are inherited). We find that father's occupation is uncorrelated with risk perception code. Rather, as Table 4 shows, we find a positive correlation of the risk perception code with membership of business associations. The higher the number of memberships, lower is the perception of risk in Table 4, where percentages are mentioned in parentheses.

Table 4. Risk Code* Membership Crosstabulation

\begin{tabular}{|l|c|c|c|}
\hline $\begin{array}{l}\text { Association } \\
\text { Membership }\end{array}$ & $\begin{array}{c}\text { Risk Code 1 } \\
\text { (High Risk) [Per cent } \\
\text { of Total] }\end{array}$ & $\begin{array}{c}\text { Risk Code 2 } \\
\text { (Low Risk) [Per cent } \\
\text { of Total] }\end{array}$ & $\begin{array}{c}\text { Total [Per } \\
\text { cent] }\end{array}$ \\
\hline Zero & $21[0.55]$ & $17[0.45]$ & $38[100]$ \\
\hline One & $11[0.41]$ & $16[0.59]$ & $27[100]$ \\
\hline More than One & $2[0.33]$ & $4[0.67]$ & $6[100]$ \\
\hline
\end{tabular}

Source: Author.

Clearly, higher number of memberships in associations (which comes with associated membership fees) is exhibited by entrepreneurs who are established in business and who benefit from information exchange, networking with other members and lobby the government. Therefore, our data provides support for hypothesis H1d, which differentiates between family influence and business network's effect on perception of risk. The latter is significantly positively correlated with experience in our data, but not correlated with father's profession, underscoring the process of becoming an entrepreneur requires access to business networks and associations, which allow access to information and mitigate risk perception. Podoynitsyna, Bij \& Song (2012) find a similar result in the context of mixed emotions for entrepreneurship.

Clubbing hypotheses H1a., b., c. and d., we conclude that entrepreneurial risk perception varies according to experience in the following manner: novice entrepreneurs have a negative location-based CFT coupled with high perception of risk whereas those with more experience exhibit the opposite behavior. This leads us to confirm hypothesis $\mathrm{H} 1$ using our data:

H1. Risk perception and CFT is not constant for different cohorts of entrepreneurs. 
Test of Representativeness of Sample: Evidence of Missing Middle Enterprise Size

Tying up with our discussion in the introduction, we mentioned the absence of a "middle size" of enterprises in Bihar, the reason being the prevalence of poor law and order conditions in the state prior to 2006 (Chakrabarti 2013). We test for this in the population of all enterprises in Bihar for 2014-15, just prior to our survey in 2016. Using secondary data from the Registrar of Companies, Patna (which has the incorporation details as well as details of authorized and paid-up capital), we find from Table 5 that the coefficient of variation of financials of all registered units exhibit very high variance relative to the mean.

Table 5. Coefficient of Variation for Financials in Selected Sectors for 2014-15

\begin{tabular}{|l|c|c|}
\hline \multirow{2}{*}{ Sub-sectors in Food Processing } & \multicolumn{2}{|c|}{ Coefficient of Variation } \\
\cline { 2 - 3 } & Authorized Capital & Paid-up Capital \\
\hline Dairy & 2.82 & 4.35 \\
\hline Cold Storage & 0.99 & 0.91 \\
\hline Rice Mills & 2.04 & 2.82 \\
\hline Animal Feeds & 1.27 & 1.49 \\
\hline
\end{tabular}

Source: Authors' own calculations using data from Registrar of Companies, Patna, Bihar.

The values for coefficient of variation (standard deviation normalized by the mean) are either very close to one (only for cold storage) or greater than one (for all other sub-sectors). Noting that the values of authorized and paid-up capital are in fact strictly positive, this amount of variation in the data must arise from an extreme size distribution with many small and some large firms with a missing middle size. This non-normality in the data is reflected in our sample. Given this variability in projects by size in our sample, we show that our sample is representative of the population.

\section{Policy Recommendations}

From a policy perspective, what is most interesting is that we could not establish any relationship (be it at the level of a correlation analysis or a causal analysis) between government subsidy available to the unit or the functional status of the unit or its marketing status and perception of risk. Nor were variables related to access to finance (such as loan access, rates of interest, working capital etc.) which could significantly explain perception of risk. We stress that we measure perception of risk in our study, and do not investigate constraints to doing business. Access to finance is a well-known constraint in the functioning of a business, but the extent to which it affects perception of risk is another matter altogether.

The denouement of the nascent industrial scenario in Bihar (post-2006) is beholden to its troubled past, with mis-governance up to 2000 (Mukherji and Mukherji 2012), which gave rise to the local kidnapping industry posing ransom threats to businessmen in the state leading up to the bifurcation of the state in 2000 (where south Bihar with all its mineral resources and heavy mining-based 
industries was lost to the newly carved state of Jharkhand). The post-2000 Bihar scenario presents a sharp decline up to 2006, in terms of all macro-indicators of state performance. The interesting turnaround of the state starts with the new government, which ensured a return to law and order (putting criminals behind bars) in the state. The second term of the same government (2011 onward) has shown a similar but a somewhat reduced pace of reforms in the state. The jump in business confidence is seen in the increase in registered manufacturing year-onyear.

It is an interesting observation for us to find that some existing entrepreneurs (particularly in rice milling) are considering Assam as an alternative state for expansion of business interests and not Bihar. In this context, the second and more nebulous variable which needs to be addressed after law and order can be termed overall ease of doing business in Bihar. An existing World Bank Group report (2015) ranks Bihar a modest 21 among 32 states (Gujarat is the leading state with Jharkhand at a surprising 3rd rank, Assam with a much lower rank of 22 and West Bengal with an intermediate 11th rank). This study uses eight parameters (setting up a business, allotment of land and obtaining construction permit, complying with environmental procedures, complying with labor regulations, infrastructurerelated utilities, registering and complying with tax procedures, carrying out inspections and enforcement of contracts) to create the ranking among states. Our initial interaction with entrepreneurs reveals a picture that is consonance with this ranking, which should be much enhanced in the near future if Bihar hopes to catch up with other states in terms of industrial achievements.

For our sample with the underlying bimodal distribution, with many small units and some very large units, we do not find that access to finance explaining business risk perception significantly. Access to finance does not matter for the large units, but it does matter crucially for the small units, which on the overall cancel out in the entire sample. The same logic applies for government subsidies. In sum, the only variables which showed any systematic patterns had to do with two entrepreneurial characteristics (experience and information access (proxied by membership of associations)). For Bihar, with the presence of many small and unprofessionally managed units coexisting with some large established enterprises, the nitpicking with respect to financial incentives through policy (subsidies and incentive structures) is unlikely to yield productive outcomes. Development of strong business networks and entrepreneurial coaching and exposure to the supply chain are potential directions for industrial policy to focus on rather than keeping the focus exclusively on pecuniary incentives.

\section{Conclusions}

Entrepreneurial expectations are not formed in a vacuum. It takes into account the local conditions and projects forward. Borrowing from explanations provided in Chakrabarti (2013), Mukherji and Mukherji (2012) and responses from entrepreneurs, we conjecture that the absence of a middle size is because these firm sizes were the most easy and lucrative targets for the kidnapping industry 
prior to 2006. The small firms and establishments in the informal sector are not profitable enough for demands of ransom, and large industries can purchase their protection from criminals. It is the middle size that suffers from this problem of threats of the private kidnapping industry.

In this paper, we measure the extent of the "entrepreneurial regret" in not being able to expand in the perception of risk of doing business by the entrepreneur by investigating the extent to which "being in Bihar" matters. This investigation adds to the relatively nascent literature on forced entrepreneurship: that doing business is not always about the natural drive of the human spirit to discover opportunities and convert them to profitable ventures, as the standard literature on identity in entrepreneurship would have us believe. To some extent, this is a comment about how "non-entrepreneurial" mind-sets cope in a business scenario: essentially, the story of the reluctant entrepreneur.

\section{Acknowledgements}

The author would like to thank the IGC, LSE, London for financing this study and participants in the $13^{\text {th }}$ Annual International Symposium on Economic Theory, Policy and Applications, 2-5 July 2018, Athens, Greece for useful comments that enriched the final paper. Additional comments from Prof. Anjan Mukherji and Dr. Maitreesh Ghatak (LSE) on the final Report of the project are gratefully acknowledged. Dr. Barna Ganguli's help in conducting the survey in Bihar, alongside research assistance from Amresh Kumar and Prabhat Kumar is worthy of mention. Asian Development Research Institute (ADRI, Patna) helped me in many arrangements for the study and the author thanks Dr. Shaibal Gupta, Dr. Sunita Lall and Dr. Prabhat Ghosh for their contribution for aiding the completion of the project.

\section{References}

Baron RA (2000) Psychological perspectives on entrepreneurship: Cognitive and social factors in entrepreneurs' success. Current directions in psychological science 9(1): 15-18.

Baron RA (2008) The role of affect in the entrepreneurial process. Academy of management Review 33(2): 328-340.

Baron RA, Markman GD (1999) Cognitive mechanisms: Potential differences between entrepreneurs and non-entrepreneurs. Frontiers of entrepreneurship research, 123137.

Baum JR, Locke EA (2004) The relationship of entrepreneurial traits, skill, and motivation to subsequent venture growth. Journal of applied psychology 89(4): 587.

Baum JR, Locke EA, Smith KG (2001) A multidimensional model of venture growth. Academy of management journal 44(2): 292-303.

Baumol WJ (1993) Formal entrepreneurship theory in economics: Existence and bounds. Journal of business venturing, 8(3): 197-210.

Burke PJ (2004) Identities, Events and Moods. In Turner JH (ed). Theory and Research on Human Emotions (21): 25-49. New York: Elsevier Ltd. 
Burke PJ (1980) The Self: Measurement Requirements from an Interactionist Perspective. Social Psychology Quarterly 43(1): 18-29.

Burke PJ (1991a) Identity Processes and Social Stress. American Sociological Review 56(6): 836-849.

Burke PJ (1991b) Attitudes, Behavior and the Self. In Howard JA, Callero PL (eds). The Self-Society Dynamic: Cognition, Emotion and Action, 189-208. New York: Cambridge University Press.

Burke PJ, Stets JE (2009) Identity theory. Oxford University Press.

Cardon MS, Wincent J, Singh J, Drnovsek M (2009) The nature and experience of entrepreneurial passion. Academy of management Review 34(3): 511-532.

Cast AD (2004) Well-being and the transition to parenthood: An identity theory approach. Sociological Perspectives 47(1): 55-78.

Chakrabarti R (2013) Bihar Breakthrough: The Turnaround of a Beleaguered State. Rupa Publications India Pvt. Ltd.

Chen XP, Yao X, Kotha S (2009) Entrepreneur passion and preparedness in business plan presentations: a persuasion analysis of venture capitalists' funding decisions. Academy of Management journal 52(1): 199-214.

Dawson C, Henley A (2013) Over-optimism and entry and exit from self-employment. International Small Business Journal 31(8): 938-954.

Falck O, Heblich S, Luedemann E (2012) Identity and entrepreneurship: do school peers shape entrepreneurial intentions? Small Business Economics 39(1): 39-59.

Gaglio CM (2004) The role of mental simulations and counterfactual thinking in the opportunity identification process. Entrepreneurship Theory and Practice, 28(6): 533-552.

Gaglio CM, Katz JA (2001) The psychological basis of opportunity identification: Entrepreneurial alertness. Small business economics 16(2): 95-111.

Gartner WB (1988) "Who is an entrepreneur?" is the wrong question. American journal of small business, 12(4): 11-32.

Gartner WB, Shaver KG, Gatewood E, Katz JA (1994) Finding the entrepreneur in entrepreneurship.

Gecas V (1982) The self-concept. Annual review of sociology 8(1): 1-33.

Gimeno J, Folta TB, Cooper AC, Woo CY (1997) Survival of the fittest? Entrepreneurial human capital and the persistence of underperforming firms. Administrative science quarterly, 750-783.

Haynie JM, Shepherd DA, McMullen JS (2009) An opportunity for me? The role of resources in opportunity evaluation decisions. Journal of Management studies 46(3): 337-361.

Hmieleski KM, Corbett AC (2008) The contrasting interaction effects of improvisational behavior with entrepreneurial self-efficacy on new venture performance and entrepreneur work satisfaction. Journal of business venturing 23(4): 482-496.

Kahneman D, Tversky A (1973) On the psychology of prediction. Psychological review 80(4): 237.

Kihlstrom RE, Laffont JJ (1979) A general equilibrium entrepreneurial theory of firm formation based on risk aversion. Journal of political economy 87(4): 719-748.

Markman GD, Baron RA, Balkin DB (2005) Are perseverance and self-efficacy costless? Assessing entrepreneurs' regretful thinking. Journal of Organizational Behavior: The International Journal of Industrial, Occupational and Organizational Psychology and Behavior 26(1): 1-19.

McCall GJ, Simmons JL (1978) Identities and interactions: An examination of human associations in everyday life (Rev. ed.). New York, 
McClelland DC (1965) N achievement and entrepreneurship: A longitudinal study. Journal of Personality and Social Psychology 1(4): 389.

McGrath RG, MacMillan IC (2000) The entrepreneurial mindset: Strategies for continuously creating opportunity in an age of uncertainty (Vol. 284).

Mukherji A, Mukherji A (2012) Bihar: What Went Wrong? And What Changed? NIPFP Working Paper No. 2012-107.

Munshi K (2010) The Birth of a Business Community: Historical Disadvantage and Contemporary Mobility in India. Review of Economic Studies, forthcoming.

Murnieks CY, Mosakowski EM (2007) Who Am I? Looking Inside the "Entrepreneurial Identity", Frontiers of Entrepreneurship Research 27 (5): Article 5. Retrieved from https://bit.ly/2PLMtOy.

Murnieks CY, Mosakowski E, Cardon MS (2014) Pathways of passion: Identity centrality, passion, and behavior among entrepreneurs. Journal of Management 40(6): 15831606.

Newman M (2018) Networks. Oxford university press. Second edition.

Noy C (2008) Sampling knowledge: the hermeneutics of snowball sampling in qualitative research, International Journal of Social Research Methodology 11 (4): 327-344

Podoynitsyna K, Van der Bij H, Song M (2012) The role of mixed emotions in the risk perception of novice and serial entrepreneurs. Entrepreneurship theory and practice 36(1): $115-140$.

Russo JE, Schoemaker PJ (1992) Managing overconfidence. Sloan management review 33(2): 7-17.

Sánchez JC, Carballo T, Gutiérrez A (2011) The entrepreneur from a cognitive approach. Psicothema 23(3): 433-438.

Schumpeter JA (1934) Change and the Entrepreneur. Essays of JA Schumpeter.

Shane S, Venkataraman S 2000 The promise of entrepreneurship as a field of research. Academy of management review 25(1): 217-226.

Sitkin SB, Pablo AL (1992) Reconceptualizing the determinants of risk behavior. Academy of management review 17(1): 9-38.

Sitkin SB, Weingart LR (1995) Determinants of risky decision-making behavior: A test of the mediating role of risk perceptions and propensity. Academy of management Journal 38(6): 1573-1592.

Stryker S, Burke PJ (2000) The past, present, and future of an identity theory. Social psychology quarterly, 284-297.

Wadeson N (2006) Cognitive aspects of entrepreneurship: decision-making and attitudes to risk. In The Oxford handbook of entrepreneurship.

Zhao H, Seibert SE, Hills GE (2005) The mediating role of self-efficacy in the development of entrepreneurial intentions. Journal of applied psychology 90(6):1265. 